\title{
A Ruthenium/Phosphoramidite-catalyzed Asymmetric Interrupted Metallo-Ene Reaction
}

\author{
Barry M. Trost and Michael C. Ryan \\ Department of Chemistry, Stanford University, Stanford, CA 94305-5080 \\ Supporting Information
}

Table of Contents

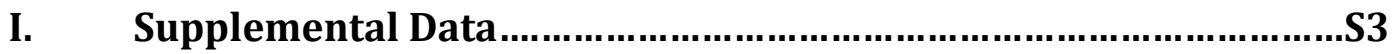

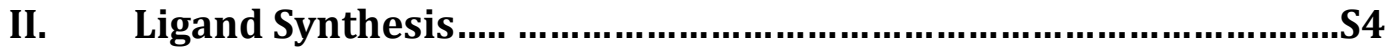

III. Substrate Synthesis.................................................................

IV. Asymmetric Interrupted Metallo-ene reaction ...........................S25

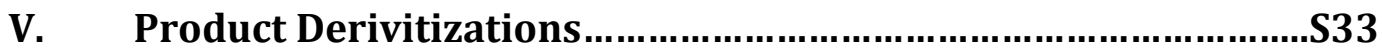

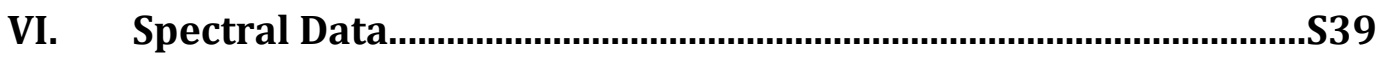




\section{Experimental Details}

All reactions were performed in flame- or oven-dried glassware with magnetic stirring under a nitrogen or argon atmosphere using freshly distilled or column-dried solvents. All other commercial reagents were used without purification unless otherwise noted. Air and moisture sensitive liquids and solutions were transferred via stainless steel syringe or cannula and introduced into the reaction vessel through rubber septa. Reactions conducted below room temperature were cooled by an external bath: dry ice in acetone for $-78{ }^{\circ} \mathrm{C}$ or ice in water for $0{ }^{\circ} \mathrm{C}$. Thin-layer chromatography was performed on EMD silica gel $60 \mathrm{~F} 254$ plates $(0.25 \mathrm{~mm})$; visualization of the developed chromatogram was performed by fluorescence quenching and staining with aqueous ceric ammonium molybdate, $p$ - anisaldehyde, or potassium permanganate. Organic solutions were concentrated by rotary evaporation below $40{ }^{\circ} \mathrm{C}$ at ca. $25 \mathrm{~mm} \mathrm{Hg}$. Chromatographic purification of products was accomplished using forced-flow chromatography on silica gel (particle size 0.040-0.063 mm). All isolated and characterized compounds were $>90 \%$ pure as judged by $1 \mathrm{H}-\mathrm{NMR}$ spectroscopic analysis unless noted otherwise. 1H and 13C NMR spectroscopy were performed on a $400 \mathrm{MHz}$ NMR spectrometer Varian Mercury console Sun Blade 100 operating at 400 $(1 \mathrm{H})$ and $100 \mathrm{MHz}(13 \mathrm{C})$, respectively, as well as on a $300 \mathrm{MHz}$ NMR spectrometer Varian Inova console Sun Sparcstation 5 operating at $300(1 \mathrm{H})$ and $75 \mathrm{MHz}(13 \mathrm{C})$, respectively. Chemical shifts are reported in ppm relative to residual protio solvent signals; all 13C NMR spectra are proton decoupled. Data for $1 \mathrm{H}$ are reported as chemical shift $(\delta \mathrm{ppm})$, multiplicity $(\mathrm{s}=$ singlet, $\mathrm{d}=$ doublet, $\mathrm{t}=$ triplet, $\mathrm{q}=$ quartet, quint = quintet, sex $=$ sextet, sept $=$ septet, oct $=$ octet, $\mathrm{m}=$ multiplet, app. = apparent), coupling constant, integration); data for $13 \mathrm{C}$ are reported in terms of chemical shift. Infrared spectroscopic data was recorded on sodium chloride plates as thin films on a Thermo Scientific Nicolet IR100 FT-IR spectrometer. Mass spectrometry data were collected by LC/ESI-MS on a Waters Acquity UPLC and Thermo Fisher Exactive mass spectrometer scanning m/z 100-1200. The LC conditions were 95\% Solvent A (0.1\% formic acid in water) held 1 minute then ramped to $98 \%$ Solvent B $(0.1 \%$ formic acid in acetonitrile) in 2 minutes, and held for 3 minutes. The column was a 2.1x30mm Zorbax C18 3.5 um and the flow rate was $0.4 \mathrm{~mL} / \mathrm{min}$. Chiral HPLC analysis was performed on a Thermo Separation Products Spectra Series P-100 using Chiralcel R and Chiralpak R columns. 


\section{Supplemental Data}

Table S1. Additional Interrupted Metallo-ene reactions with Ru-Sulfoxide Complexes

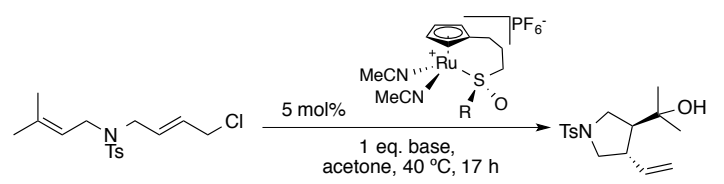

\begin{tabular}{cccccc}
\hline entry & $\mathrm{R}$ & base & solv. & NMR yield & $e e^{b}$ \\
\hline 1 & $p$-anisyl & $\mathrm{NaHCO}_{3}$ & acetone & $64 \%$ & $64 \%$ \\
2 & $p$-anisyl & $\mathrm{NaHCO}_{3}$ & cyclopentanone & $86 \%$ & $55 \%$ \\
3 & $t$-Bu & $\mathrm{NaHCO}_{3}$ & acetone & $93 \%$ & $33 \%$ \\
4 & $m$-xylyl & $\mathrm{NaHCO}_{3}$ & acetone & $76 \%$ & $47 \%$ \\
5 & $o$-anisyl & $\mathrm{NaHCO}_{3}$ & acetone & $57 \%$ & $50 \%$ \\
6 & $p$-tolyl & $\mathrm{NaHCO}_{3}$ & acetone & $97 \%$ & $60 \%$ \\
7 & 2-naphthyl & $\mathrm{NaHCO}_{3}$ & acetone & $95 \%$ & $46 \%$ \\
8 & $p$-anisyl & $\mathrm{Na}_{2} \mathrm{CO}_{3}$ & acetone & $56 \%$ & $46 \%$ \\
9 & $p$-anisyl & $\mathrm{Na}_{2} \mathrm{HPO}_{4} \cdot 7 \mathrm{H}_{2} \mathrm{O}$ & acetone & $83 \%$ & $52 \%$ \\
\hline
\end{tabular}

a Determined by integration using 1,1,2,2-tetrachloroethane as

an internal standard.

b Determined by chiral HPLC

Table S2. Additional Ligands Screened for the Asymmetric Metallo-ene Reaction
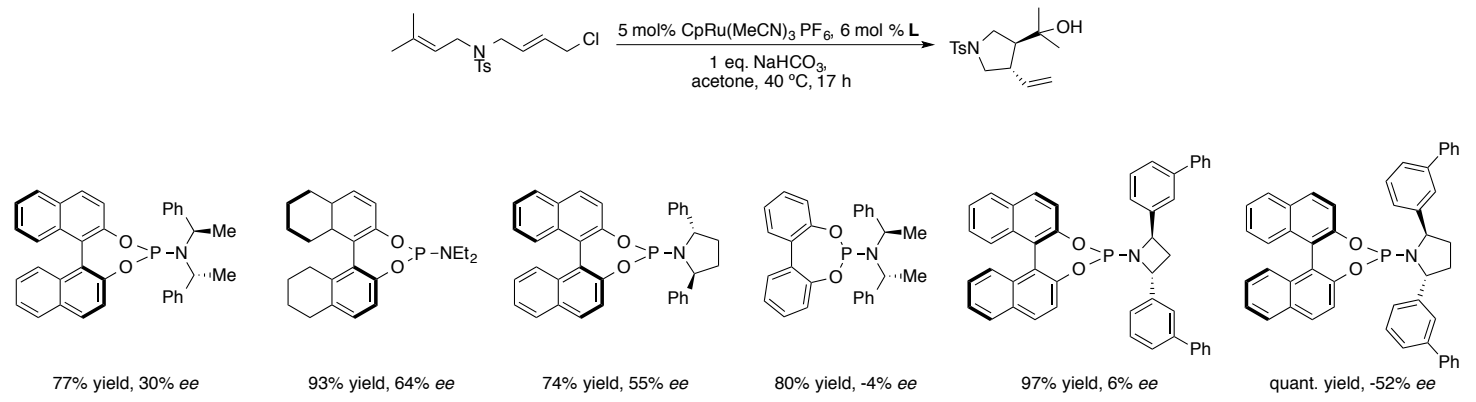

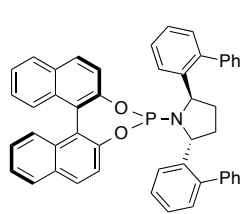

quant. yield, $-7 \%$ ee<smiles>O=C(CCc1ccccc1)P(c1ccccc1)N1C2CCCCC2P1c1ccccc1</smiles>

$63 \%$ yield, $2 \%$ ee

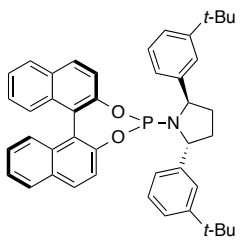

$85 \%$ yield, $-55 \%$ ee

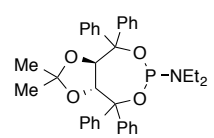

$80 \%$ yield, $20 \%$ ee

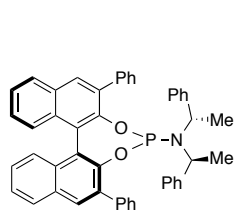

$77 \%$ yield, $56 \%$ ee

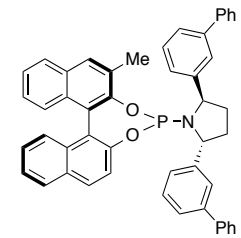

$60 \%$ yield, $-2 \%$ ee

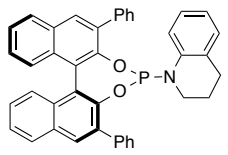

$50 \%$ yield, $5 \%$ ee

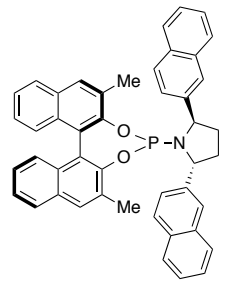

$28 \%$ yield, $-32 \%$ ee

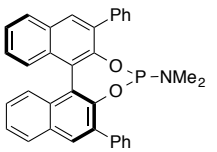

$94 \%$ yield, $48 \%$ ee

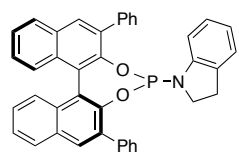

$78 \%$ yield, $60 \%$ ee

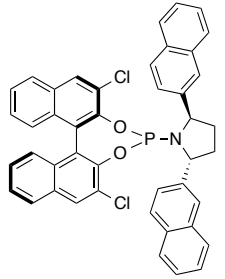

$35 \%$ yield, $-20 \%$ ee

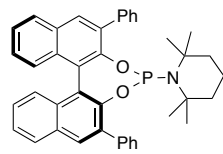

$73 \%$ yield, $11 \%$ ee

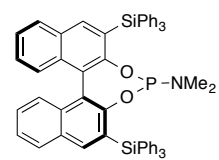

$86 \%$ yield, $4 \%$ ee

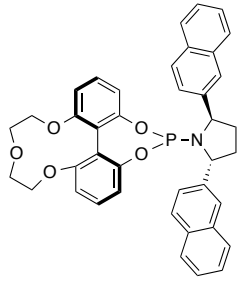

$55 \%$ yield, $-20 \%$ ee 


\section{Ligand synthesis}

benzyl ((11bS)-2,6-di-p-tolyldinaphtho[2,1-d:1',2'-f][1,3,2]dioxaphosphepin-4-yl)-L-prolinate (4g)
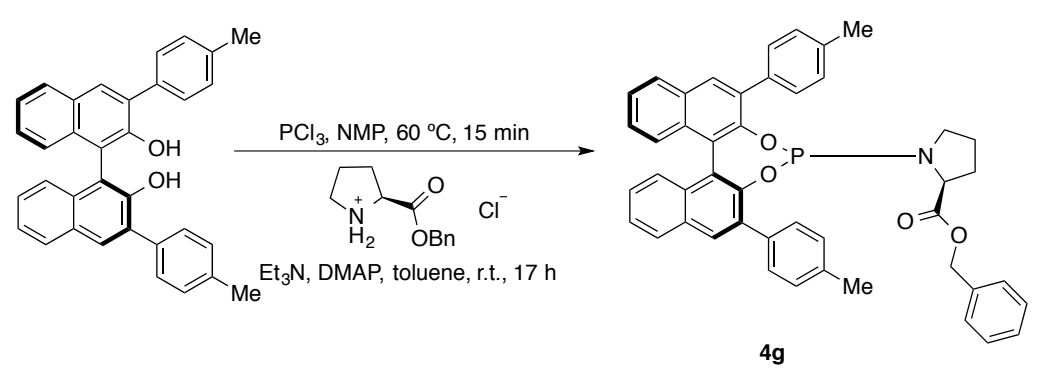

$\mathrm{PCl}_{3}$ (1 mL, $11.4 \mathrm{mmol}, 22.8$ eq.) and N-methyl-2-pyrrolidinone (1 drop) was added to a flamedried $25 \mathrm{~mL}$ round bottom flask with stir bar under argon containing (S)-3,3'-di- $p$-tolyl-[1,1'binaphthalene]-2,2'-diol i (233 mg, $0.5 \mathrm{mmol}, 1$ eq.) at room temperature. The reaction was placed into a $60{ }^{\circ} \mathrm{C}$ oil bath and stirred for 15 minutes. After cooling to room temperature, the reaction was diluted with $5 \mathrm{~mL}$ of distilled toluene and concentrated in vacuo. The resulting solid was azeotroped two more times with toluene to remove the excess $\mathrm{PCl}_{3}$. A solution of the resulting foamy solid was dissolved in distilled toluene $(1.25 \mathrm{~mL})$ and added via a syringe to a separate flame-dried $25 \mathrm{~mL}$ round bottom flask with stir bar under argon containing (S)-proline benzyl ester hydrochloride (181 mg, $0.75 \mathrm{mmol}, 1.5$ eq.), $\mathrm{Et}_{3} \mathrm{~N}(0.35 \mathrm{~mL}, 2.5 \mathrm{mmol}, 5 \mathrm{eq}$ ), and DMAP (a chip) in toluene (1.25 mL). The reaction was stirred at room temperature for 17 hours The crude material was purified by flash chromatography on silica gel (3:1:0.01 hexanes:DCM: $\left.\mathrm{Et}_{3} \mathrm{~N}\right)$ to give benzyl ((11bS)-2,6-di-p-tolyldinaphtho[2,1-d:1',2'$f][1,3,2]$ dioxaphosphepin-4-yl)- $L$-prolinate $\mathbf{4 g}$ as a white solid (100 $\mathrm{mg}, 0.03 \mathrm{mmol}, 28 \%$ yield). [ $\mathrm{R}_{\mathrm{f}}=0.17$ (9:1:0.1 hexanes:EtOAc:Et $\left.\left.{ }_{3} \mathrm{~N}\right)\right] ;[\alpha]_{\mathrm{D}}{ }^{25}=+208.07^{\circ}\left(1.0, \mathrm{CHCl}_{3}\right)$; IR (thin film): 3030, 2920, 2361, 2341, 2250, 1736, 1655, 1616, 1592, 1515, 1496, 1446, 1420, 1396, 1357, 1331, 1308, 1266, 1247, 1178, $1150,1133,1098,1075,1020,994,961,906,883,844,819,787,763,748,727,696,685,670,647,633$, $618,611,599,560,545,526,507 \mathrm{~cm}^{-1} ;{ }^{1} \mathrm{H}-\mathrm{NMR}\left(400 \mathrm{MHz} ; \mathrm{CDCl}_{3}\right): \delta$ 8.09-8.03 (m, 2H), 7.99-7.92 (m, 2H), 7.74-7.67 (m, 4H), 7.48-7.16 (m, 15H), 4.99-4.86 (q, $J=12.1 \mathrm{~Hz}, 2 \mathrm{H}), 3.62-3.57(\mathrm{~m}, 1 \mathrm{H}), 3.14-3.10$ (m, 1H), 2.70-2.64 (m, 1H), 2.45-2.39 (s, 3H), 2.35-2.24 (s, 3H), 1.71-1.62 (m, 1H), 1.48-1.41 (m, 1H), 1.31-1.24 (m, 2H); ${ }^{13} \mathrm{C}-\mathrm{NMR}\left(101 \mathrm{MHz}, \mathrm{CDCl}_{3}\right): \delta$ 173.93, 148.44, 147.73, 137.48, 137.20, 136.20, 135.45, $135.16,134.95,134.11,132.63,132.52,131.47,131.24,131.12,130.76,130.24,130.08,129.84,129.76$, $129.47,129.09,128.68,128.59,128.51,128.25,127.85,127.24,127.19,126.16,125.34,125.12,124.44$, $66.47,59.40$ (d), 45.86 (d), 30.60 (d), 24.31, 21.53, 21.46; ${ }^{31 P-N M R ~(162 ~ M H z, ~} \mathrm{CDCl}_{3}$ ): $\delta$ 150.31; HR-MS $(\mathrm{m} / \mathrm{z}):\left[\mathrm{M}+\mathrm{Na}^{+}+\mathrm{O}\right]$ calcd for $\mathrm{C}_{46} \mathrm{H}_{38} \mathrm{NNaO}_{5} \mathrm{P}: 738.2385$; found: 738.2355 . 


\section{benzyl ((11bS)-2,6-di(naphthalen-2-yl)dinaphtho[2,1-d:1',2'-f][1,3,2]dioxaphosphepin-4-yl)-L- prolinate (4h)}
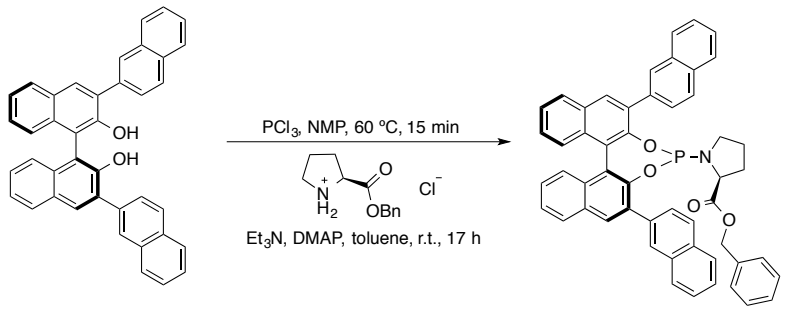

$\mathrm{PCl}_{3}$ (1 mL, $11.4 \mathrm{mmol}, 30.8$ eq.) and N-methyl-2-pyrrolidinone (1 drop) was added to a flamedried $25 \mathrm{~mL}$ round bottom flask with stir bar under argon containing (S)-[2,2':4',1":3",2"'quaternaphthalene]-2",3'-diol ${ }^{1}$ (200 $\mathrm{mg}, 0.37 \mathrm{mmol}, 1 \mathrm{eq}$ ) $)$ at room temperature. The reaction was placed into a $60{ }^{\circ} \mathrm{C}$ oil bath and stirred for 15 minutes. After cooling to room temperature, the reaction was diluted with $5 \mathrm{~mL}$ of distilled toluene and concentrated in vacuo. The resulting solid was azeotroped two more times with toluene to remove the excess $\mathrm{PCl}_{3}$. A solution of the resulting foamy solid was dissolved in distilled toluene $(0.5 \mathrm{~mL})$ and added via a syringe to a separate flame-dried $25 \mathrm{~mL}$ round bottom flask with stir bar under argon containing $(S)$-proline benzyl ester hydrochloride (89 $\mathrm{mg}$, $0.37 \mathrm{mmol}, 1$ eq.), $\mathrm{Et}_{3} \mathrm{~N}$ (0.258 mL, $1.85 \mathrm{mmol}, 5$ eq.), and DMAP (a chip) in toluene (0.5 mL). The reaction was stirred at room temperature for 17 hours The crude material was purified by flash chromatography on silica gel (3:1:0.01 hexanes:DCM: $\left.\mathrm{Et}_{3} \mathrm{~N}\right)$ to give benzyl ((11bS)-2,6-di(naphthalen-2yl)dinaphtho[2,1-d:1',2'-f][1,3,2]dioxaphosphepin-4-yl)- - -prolinate $\mathbf{4 h}$ as a white solid give (70 $\mathrm{mg}, 0.09$ mmol, $24 \%$ yield). $\left[\mathrm{R}_{\mathrm{f}}=0.13\right.$ (9:1:0.1 hexanes:EtOAc:Et $\left.\left.{ }_{3} \mathrm{~N}\right)\right] ;[\alpha]_{\mathrm{D}}{ }^{25}=+270.41^{\circ}\left(1.0, \mathrm{CHCl}_{3}\right) ; \mathrm{IR}$ (thin film): $3012,2911,1718,1571,1475,1428,1390,1339,1219,1184,1157,1135,1120,1081,1005,965,940$, 928, 882, 845, 801, 779, 739, 681, $651 \mathrm{~cm}^{-1}$; ${ }^{1} \mathrm{H}-\mathrm{NMR}\left(400 \mathrm{MHz} ; \mathrm{CDCl}_{3}\right): \delta 8.23(\mathrm{~d}, J=11.8 \mathrm{~Hz}, 2 \mathrm{H}), 8.16$ (d, $J=5.8 \mathrm{~Hz}, 2 \mathrm{H}), 8.01(\mathrm{~d}, J=8.1 \mathrm{~Hz}, 2 \mathrm{H}), 7.97-7.86(\mathrm{~m}, 5 \mathrm{H}), 7.81(\mathrm{~d}, J=8.6 \mathrm{~Hz}, 1 \mathrm{H}), 7.77(\mathrm{~d}, J=7.4 \mathrm{~Hz}$, 1H), 7.52-7.41 (m, 7H), 7.33 (q, J = 7.7 Hz, 2H), 7.18-7.13 (m, 3H), 6.87 (d, $J=6.0 \mathrm{~Hz}, 2 \mathrm{H}), 4.43$ (q, J = 17.5 $\mathrm{Hz}, 2 \mathrm{H}), 3.34(\mathrm{t}, J=9.1 \mathrm{~Hz}, 1 \mathrm{H}), 3.08(\mathrm{dt}, J=10.1,5.3 \mathrm{~Hz}, 1 \mathrm{H}), 2.40-2.33(\mathrm{~m}, 1 \mathrm{H}), 1.44-1.30(\mathrm{~m}, 2 \mathrm{H}), 0.95-$ $0.84(\mathrm{~m}, 2 \mathrm{H}) ;{ }^{13} \mathrm{C}-\mathrm{NMR}\left(101 \mathrm{MHz}, \mathrm{CDCl}_{3}\right): \delta$ 173.23, 148.11, 147.52, 135.74, 135.68, 135.35, 134.73, 134.69, 133.93, 133.28, 133.22, 132.58, 132.52, 132.49, 132.43, 131.22, 130.93, 130.86, 130.15, 129.02, $128.99,128.66,128.41,128.30,128.26,128.16,128.11,128.04,127.97,127.73,127.63,127.45,127.35$, 126.96, 126.94, 126.20, 126.15, 126.11, 126.10, 125.89, 125.80, 125.18, 124.98, 65.85, 58.98 (d), 45.07 (d), 29.96 (d), 23.88; ${ }^{31} \mathrm{P}-\mathrm{NMR}\left(162 \mathrm{MHz}, \mathrm{CDCl}_{3}\right): \delta$ 150.66; HR-MS (m/z): [M + $\mathrm{Na}^{+}+$0] calcd for $\mathrm{C}_{52} \mathrm{H}_{38} \mathrm{NNaO}_{5} \mathrm{P}: 810.2385$; found: 810.2385. 


\section{benzyl ((11bS)-2,6-bis(3,5-dimethylphenyl)dinaphtho[2,1-d:1',2'-f][1,3,2]dioxaphosphepin-4-yl)- $L$-prolinate (4i)}
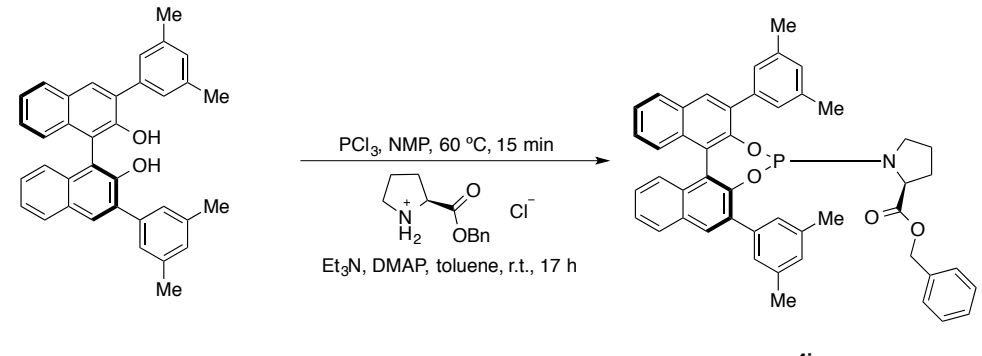

$\mathrm{PCl}_{3}$ (1 mL, $11.4 \mathrm{mmol}, 22.8$ eq.) and N-methyl-2-pyrrolidinone (1 drop) was added to a flamedried $25 \mathrm{~mL}$ round bottom flask with stir bar under argon containing $(S)$-3,3'-bis(3,5-dimethylphenyl)[1,1'-binaphthalene]-2,2'- $\operatorname{diol}^{1}$ (247 $\mathrm{mg}, 0.5 \mathrm{mmol}, 1 \mathrm{eq}$.) at room temperature. The reaction was placed into a $60{ }^{\circ} \mathrm{C}$ oil bath and stirred for 15 minutes. After cooling to room temperature, the reaction was diluted with $5 \mathrm{~mL}$ of distilled toluene and concentrated in vacuo. The resulting solid was azeotroped two more times with toluene to remove the excess $\mathrm{PCl}_{3}$. A solution of the resulting foamy solid was dissolved in distilled toluene $(0.5 \mathrm{~mL})$ and added via a syringe to a separate flame-dried $25 \mathrm{~mL}$ round bottom flask with stir bar under argon containing $(S)$-proline benzyl ester hydrochloride (121 mg, 0.5 mmol, 1 eq.), $\mathrm{Et}_{3} \mathrm{~N}$ (0.348 mL, $2.5 \mathrm{mmol}, 5$ eq.), and DMAP (a chip) in toluene (0.5 mL). The reaction was stirred at room temperature for 17 hours The crude material was purified by flash chromatography on silica gel $\left(1: 1: 0.01\right.$ hexanes:toluene: $\left.\mathrm{Et}_{3} \mathrm{~N}\right)$ to give benzyl $((11 \mathrm{~b} S)-2,6-\mathrm{bis}(3,5-$ dimethylphenyl)dinaphtho[2,1-d:1',2'-f][1,3,2]dioxaphosphepin-4-yl)-L-prolinate 4i as a light yellow solid (215 mg, $0.3 \mathrm{mmol}$, 59\% yield). [ $\mathrm{R}_{\mathrm{f}}=0.24$ (9:1:0.1 hexanes:EtOAc:Et $\left.\left.{ }_{3} \mathrm{~N}\right)\right] ;[\alpha]_{\mathrm{D}}^{25}=+211.76^{\circ}(1.0$, $\mathrm{CHCl}_{3}$ ); IR (thin film): 3389, 1722, 1620, 1581, 1476, 1434, 1380, 1339, 1317, 1296, 1247, 1215, 1199, 1155, 1135, 1119 1068, 1003, 958, 940, 891, 838, 792, 776, 742, 695, $660 \mathrm{~cm}^{-1}$; ${ }^{1} \mathrm{H}-\mathrm{NMR}$ (400 MHz; $\left.\mathrm{CDCl}_{3}\right): \delta 8.02(\mathrm{~d}, J=11.7 \mathrm{~Hz}, 3 \mathrm{H}), 7.95(\mathrm{~d}, J=8.1 \mathrm{~Hz}, 2 \mathrm{H}), 7.46-7.35(\mathrm{~m}, 8 \mathrm{H}), 7.31-7.26(\mathrm{~m}, 4 \mathrm{H}), 7.14-7.06$ $(\mathrm{m}, 2 \mathrm{H}), 7.01(\mathrm{~s}, 1 \mathrm{H}), 6.97(\mathrm{~s}, 1 \mathrm{H}), 4.92-4.85(\mathrm{~m}, 2 \mathrm{H}), 3.53(\mathrm{t}, J=8.7 \mathrm{~Hz}, 1 \mathrm{H}), 3.11-3.06(\mathrm{~m}, 1 \mathrm{H}), 2.37(\mathrm{~d}, J=$ $2.3 \mathrm{~Hz}, 12 \mathrm{H}), 2.28-2.21(\mathrm{~m}, 1 \mathrm{H}), 1.46-1.27(\mathrm{~m}, 4 \mathrm{H}) ;{ }^{13} \mathrm{C}-\mathrm{NMR}\left(101 \mathrm{MHz}, \mathrm{CDCl}_{3}\right): \delta \quad 173.50,147.92$, $147.40,137.98,137.64,137.42$, 137.29, 137.25, 135.81, 134.98, 134.96, 134.26, 132.32, 132.25, 131.09, 130.79 , 130.58, 129.60, 129.00, 128.99, 128.90, 128.87, 128.36, 128.25, 128.18, 127.97, 127.92, 127.88, $127.85,127.79,127.75,126.91,126.86,125.81,124.96,124.93,124.77,66.20,58.98$ (d), 45.13 (d), 30.20 (d), 23.94, 21.35; HR-MS (m/z): [M + $\left.\mathrm{Na}^{+}+0\right]$ calcd for $\mathrm{C}_{48} \mathrm{H}_{42} \mathrm{NNaO}_{5} \mathrm{P}: 766.2698$; found: 766.2698 . 
benzyl ((11bS)-2,6-bis(3,5-di-tert-butyl-4-methoxyphenyl)dinaphtho[2,1-d:1',2'$f][1,3,2]$ dioxaphosphepin-4-yl)- $L$-prolinate $(4 \mathrm{j})$

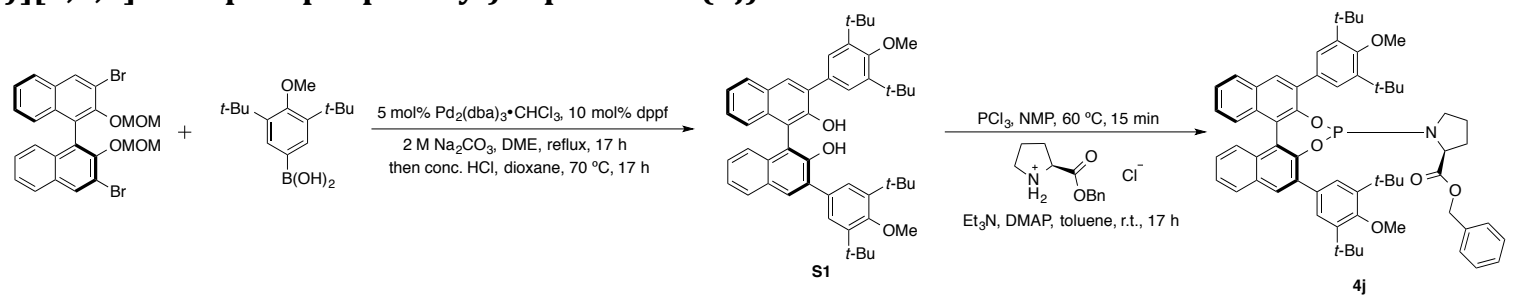

(S)-3,3'-dibromo-2,2'-bis(methoxymethoxy)-1,1'-binaphthalene' ${ }^{1}$ (1.06 g, $2 \mathrm{mmol}, 1$ equiv) and $\mathrm{Pd}_{2}(\mathrm{dba})_{3}$ (104 mg, $0.1 \mathrm{mmol}, 0.05$ eq.) were added to a round bottom flask with stir bar under an argon atmosphere. 13.4 $\mathrm{mL}$ of dry DME was added via syringe. To the mixture, with stirring, were added arylboronic acid (1.32 g, $5 \mathrm{mmol}, 2.5$ equiv) and a degassed $2 \mathrm{M}$ aqueous $\mathrm{Na}_{2} \mathrm{CO}_{3}$ solution (5.2 mL, 10.4 mmol, 5.2 equiv). The resulting mixture was stirred and heated to reflux for $10 \mathrm{~h}$, cooled to room temperature, and passed through a pad of Celite. The organic solution was evaporated to give a residue. The residue was dissolved in $\mathrm{CH}_{2} \mathrm{Cl}_{2}(20 \mathrm{~mL})$, washed successively with saturated aqueous $\mathrm{NH}_{4} \mathrm{Cl}(20$ $\mathrm{mL})$, water $(20 \mathrm{~mL})$, and brine $(20 \mathrm{~mL})$. The combined organics were dried over $\mathrm{Na}_{2} \mathrm{SO}_{4}$, filtered, and concentrated to give a crude product. Subsequent purification (silica gel chromatography 20:1 hex:EtOAc) gave the Suzuki-coupled MOM protected product which was deprotected directly. Concentrated $\mathrm{HCl}(0.2 \mathrm{~mL})$ was added to a solution of MOM protected binol in dioxane $(14 \mathrm{~mL})$. The resulting solution was heated to $70^{\circ} \mathrm{C}$ for $17 \mathrm{~h}$. The reaction mixture was cooled to room temperature and quenched by addition of sat. $\mathrm{NaHCO}_{3}$ solution $(5 \mathrm{~mL})$. The product was extracted into EtOAc $(3 \times 20$ $\mathrm{mL})$ and washed with water $(20 \mathrm{~mL})$, then brine $(20 \mathrm{~mL})$. The combined organics were dried over $\mathrm{Na}_{2} \mathrm{SO}_{4}$, filtered and concentrated to yield the crude product. Trituration/washing with $\mathrm{Et}_{2} \mathrm{O}$ provided (S)-3,3'-bis(3,5-dimethylphenyl)-[1,1'-binaphthalene]-2,2'-diol $\mathbf{S 1}$ as a white solid (1.3 g, $1.8 \mathrm{mmol}, 90 \%$ yield). $\left[\mathrm{R}_{\mathrm{f}}=0.38\right.$ (9:1 hexanes:EtOAc)]; $[\alpha]_{\mathrm{D}} 25=-23.30^{\circ}\left(1.0, \mathrm{CHCl}_{3}\right) ; \mathrm{IR}$ (thin film): 3471, 3015, 2921, 2829, 1599, 1573, 1477, 1420, 1377, 1342, 1303, 1276, 1242, 1208, 1157, 1131, 1118, 1101, 1036, 997, $896,873,841,788,771,723,698,680,656 \mathrm{~cm}^{-1} ;{ }^{1} \mathrm{H}-\mathrm{NMR}\left(400 \mathrm{MHz} ; \mathrm{CDCl}_{3}\right): \delta 8.01(\mathrm{~s}, 2 \mathrm{H}), 7.94(\mathrm{~d}, J=$ $8.0 \mathrm{~Hz}, 2 \mathrm{H}), 7.63(\mathrm{~s}, 4 \mathrm{H}), 7.39(\mathrm{t}, J=7.4 \mathrm{~Hz}, 2 \mathrm{H}), 7.32(\mathrm{t}, J=7.5 \mathrm{~Hz}, 2 \mathrm{H}), 7.27-7.25(\mathrm{~m}, 2 \mathrm{H}), 5.49(\mathrm{~s}, 2 \mathrm{H})$, 3.77 (s, 6H), $1.50(\mathrm{~s}, 36 \mathrm{H}) ;{ }^{13} \mathrm{C}-\mathrm{NMR}\left(101 \mathrm{MHz}, \mathrm{CDCl}_{3}\right): \delta 159.31,150.03,143.75,132.80,131.36,130.93$, $130.78,129.38,128.25,127.95,126.93,124.40,124.11,112.74,64.26,35.91,32.12 ;$ HR-MS (m/z): [M + $\left.\mathrm{Na}^{+}\right]$calcd for $\mathrm{C}_{50} \mathrm{H}_{58} \mathrm{NaO}_{4}$ : 745.4233; found: 745.4233.

$\mathrm{PCl}_{3}$ (1 mL, $11.4 \mathrm{mmol}, 22.8$ eq.) and N-methyl-2-pyrrolidinone (1 drop) was added to a flamedried $25 \mathrm{~mL}$ round bottom flask with stir bar under argon containing (S)-3,3'-bis(3,5-dimethylphenyl)[1,1'-binaphthalene]-2,2'-diol (362 mg, $0.5 \mathrm{mmol}, 1$ eq.) at room temperature. The reaction was placed into a $60{ }^{\circ} \mathrm{C}$ oil bath and stirred for 15 minutes. After cooling to room temperature, the reaction was diluted with $5 \mathrm{~mL}$ of distilled toluene and concentrated in vacuo. The resulting solid was azeotroped two more times with toluene to remove the excess $\mathrm{PCl}_{3}$. A solution of the resulting foamy solid was dissolved in distilled toluene $(0.5 \mathrm{~mL})$ and added via a syringe to a separate flame-dried $25 \mathrm{~mL}$ round bottom flask with stir bar under argon containing $(S)$-proline benzyl ester hydrochloride $(121 \mathrm{mg}, 0.5$ 
mmol, 1 eq.), $\mathrm{Et}_{3} \mathrm{~N}$ (0.348 mL, $2.5 \mathrm{mmol}, 5$ eq.), and DMAP (a chip) in toluene (0.5 mL). The reaction was stirred at room temperature for 17 hours. The crude material was directly purified by flash chromatography on silica gel (3:1:0.01 hexanes:DCM:Et $\left.{ }_{3} \mathrm{~N}\right)$ to give benzyl ((11bS)-2,6-bis(3,5-di-tertbutyl-4-methoxyphenyl)dinaphtho[2,1-d:1',2'-f][1,3,2]dioxaphosphepin-4-yl)-L-prolinate $4 \mathbf{j}$ as a light yellow solid (272 mg, $0.28 \mathrm{mmol}, 56 \%$ yield). $\left[\mathrm{R}_{\mathrm{f}}=0.33\left(9: 1: 0.1\right.\right.$ hexanes:EtOAc:Et $\left.\left.{ }_{3} \mathrm{~N}\right)\right] ;[\alpha]_{\mathrm{D}}{ }^{25}=+185.95^{\circ}$ (1.0, $\mathrm{CHCl}_{3}$ ); IR (thin film): 2920, 2830, 1725, 1627, 1475, 1434, 1391, 1372, 1342, 1313, 1244, 1208, $1164,1135,1119,1101,1067,997,978,895,872,813,795,782,741,688,657 \mathrm{~cm}^{-1}$; ${ }^{1} \mathrm{H}-\mathrm{NMR}(400 \mathrm{MHz}$; $\mathrm{CDCl}_{3}$ ): $\delta 8.05(\mathrm{~d}, J=10.8 \mathrm{~Hz}, 2 \mathrm{H}), 7.98(\mathrm{dd}, J=7.4,4.9 \mathrm{~Hz}, 2 \mathrm{H}), 7.77(\mathrm{~s}, 2 \mathrm{H}), 7.66(\mathrm{~s}, 2 \mathrm{H}), 7.46-7.36(\mathrm{~m}$, $4 \mathrm{H}), 7.29-7.24(\mathrm{~m}, 5 \mathrm{H}), 7.14-7.12(\mathrm{~m}, 2 \mathrm{H}), 4.83(\mathrm{q}, J=10.5 \mathrm{~Hz}, 2 \mathrm{H}), 3.73(\mathrm{~s}, 3 \mathrm{H}), 3.65(\mathrm{~s}, 3 \mathrm{H}), 3.22(\mathrm{t}, J=$ $9.5 \mathrm{~Hz}, 1 \mathrm{H}), 3.11-3.05(\mathrm{~m}, 1 \mathrm{H}), 2.31-2.25(\mathrm{~m}, 1 \mathrm{H}), 1.52-1.36(\mathrm{~m}, 36 \mathrm{H}), 0.89-0.84(\mathrm{~m}, 4 \mathrm{H}) ;{ }^{13} \mathrm{C}-\mathrm{NMR}(101$ $\mathrm{MHz}, \mathrm{CDCl}_{3}$ ): $\delta 173.31,159.30,159.24,147.72,143.33,143.23,136.01,135.54,134.08,132.44,132.02$, $131.49,131.11,131.08,130.56,129.31,128.77,128.62,128.55,128.52,128.26,128.13,127.30,127.19$, 125.95, 125.27, 125.01, 124.64, 66.38, 64.57, 64.47, 58.28 (d), 46.00 (d), 36.19, 36.12, 32.39, 31.09, 24.49; HR-MS (m/z): [M + Na+] calcd for $\mathrm{C}_{62} \mathrm{H}_{70} \mathrm{NNaO}_{6} \mathrm{P}$ : 978.4839; found: 978.4838 .

\section{Substrate Synthesis}

\section{(E)- $N$-(4-chlorobut-2-en-1-yl)-4-methyl- $N$-(3-methylbut-2-en-1-yl)benzenesulfonamide (1a)}

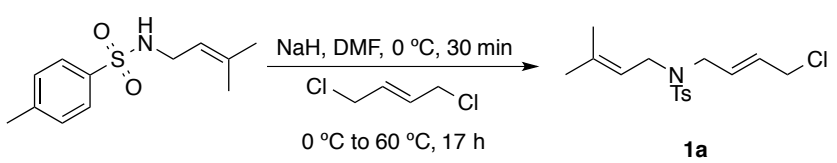

A flame-dried $25 \mathrm{~mL}$ round bottomed flask with stir bar was charged with 4-methyl- $\mathrm{N}$-(3methylbut-2-en-1-yl)benzenesulfonamide ${ }^{\mathrm{ii}}$ (1.2 g, $5 \mathrm{mmol}, 1$ eq.) and placed under argon. $25 \mathrm{~mL}$ of dry DMF was added via syringe and the solution was cooled to 0 degrees with an ice/water bath. Sodium hydride ( $60 \mathrm{wt} \%$ dispersion in mineral oil, $220 \mathrm{mg}, 5.5 \mathrm{mmol}, 1.1 \mathrm{eq}$.) was added in one portion and the reaction was allowed to stir at 0 degrees for 30 minutes. trans-1,4-dichloro-2-butene $(1.06 \mathrm{~mL}, 10 \mathrm{mmol}$, 2 eq.) was added rapidly via syringe at 0 degrees. The reaction was taken out of the ice bath and placed in a 60 degree oil bath where it was allowed to stir for 17 hours. After 17 hours, the reaction was cooled to room temperature and $15 \mathrm{~mL}$ of saturated aqueous ammonium chloride was added. The reaction was diluted with ether $(30 \mathrm{~mL})$, the layers were shaken, and separated. The aqueous phase was extracted once with ether $(30 \mathrm{~mL})$. The combined organics were washed with water $(3 \times 30 \mathrm{~mL})$, dried over $\mathrm{MgSO}_{4}$, filtered, and concentrated. Purification by silica gel chromatography (7:1 hexanes:EtOAc) gave (E)- $N$-(4-chlorobut-2-en-1-yl)-4-methyl- $N$-(3-methylbut-2-en-1-yl)benzenesulfonamide $1 \mathbf{1 a}$ as a clear liquid (1.24 g, $3.78 \mathrm{mmol}, 74 \%$ yield). [ $\mathrm{R}_{\mathrm{f}}=0.2$ (7:1 hexanes:EtOAc]; IR (thin film): 2881, 1575, 1472, $1424,1321,1243,1142,1078,1004,956,903,804,732,646,542 \mathrm{~cm}^{-1} ;{ }^{1} \mathrm{H}-\mathrm{NMR}\left(400 \mathrm{MHz} ; \mathrm{CDCl}_{3}\right): \delta$ $7.66(\mathrm{~d}, J=8.1 \mathrm{~Hz}, 2 \mathrm{H}), 7.28(\mathrm{~d}, J=8.1 \mathrm{~Hz}, 2 \mathrm{H}), 5.73-5.56(\mathrm{~m}, 2 \mathrm{H}), 4.94(\mathrm{t}, J=7.1 \mathrm{~Hz}, 1 \mathrm{H}), 3.96(\mathrm{~d}, J=6.5$ $\mathrm{Hz}, 2 \mathrm{H}), 3.75$ (app. d, $J=5.9 \mathrm{~Hz}, 4 \mathrm{H}), 2.41(\mathrm{~s}, 3 \mathrm{H}), 1.64(\mathrm{~s}, 3 \mathrm{H}), 1.57(\mathrm{~s}, 3 \mathrm{H}) ;{ }^{13} \mathrm{C}-\mathrm{NMR}\left(101 \mathrm{MHz}, \mathrm{CDCl}_{3}\right): \delta$ 
143.44, 137.49, 137.45, 130.09, 129.86, 129.71, 127.40, 118.83, 47.96, 45.00, 44.25, 25.99, 21.74, 18.11.; HR-MS (m/z): [M + Na+] calcd for $\mathrm{C}_{16} \mathrm{H}_{22} \mathrm{ClNNaO}_{2} \mathrm{~S}: 350.0958$; found: 350.0957 .

\section{$N$-((E)-4-chlorobut-2-en-1-yl)- $N$-cinnamyl-4-methylbenzenesulfonamide (1b)}

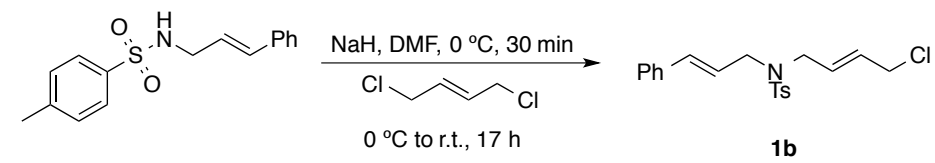

A flame-dried $25 \mathrm{~mL}$ round bottomed flask with stir bar was charged with $N$-cinnamyl-4methylbenzenesulfonamide ${ }^{2}$ (594 mg, $2.06 \mathrm{mmol}, 1$ eq.) and placed under argon. $10.3 \mathrm{~mL}$ of dry DMF was added via syringe and the solution was cooled to 0 degrees with an ice/water bath. Sodium hydride (60 wt\% dispersion in mineral oil, $90 \mathrm{mg}, 2.27 \mathrm{mmol}, 1.1 \mathrm{eq}$.) was added in one portion and the reaction was allowed to stir at 0 degrees for 30 minutes. trans-1,4-dichloro-2-butene $(0.33 \mathrm{~mL}, 3.1 \mathrm{mmol}, 1.5 \mathrm{eq}$.) was added rapidly via syringe at 0 degrees. The reaction was taken out of the ice bath and allowed to warm to room temperature where it was allowed to stir for 17 hours. After 17 hours, $5 \mathrm{~mL}$ of saturated aqueous ammonium chloride was added. The reaction was diluted with ether $(10 \mathrm{~mL})$, the layers were shaken, and separated. The aqueous phase was extracted once with ether $(10 \mathrm{~mL})$. The combined organics were washed with water ( $3 \times 10 \mathrm{~mL}$ ), dried over $\mathrm{MgSO}_{4}$, filtered, and concentrated. Purification by silica gel chromatography (9:1 hexanes:EtOAc) gave $N$ - ((E)-4-chlorobut-2-en-1-yl)- $N$-cinnamyl-4methylbenzenesulfonamide $\mathbf{1 b}$ as a clear oil (365 mg, $0.97 \mathrm{mmol}, 47 \%$ yield). $\left[\mathrm{R}_{\mathrm{f}}=0.2\right.$ (9:1 hexanes:EtOAc)]; IR (thin film): 2985, 2882, 2818, 1631, 1575, 1473, 1425, 1380, 1318, 1233, 1144, 1075, 955, 901, 832, 804, 723, 645, $542 \mathrm{~cm}^{-1} ;{ }^{1} \mathrm{H}-\mathrm{NMR}\left(400 \mathrm{MHz} ; \mathrm{CDCl}_{3}\right): \delta 7.73(\mathrm{~d}, J=8.1 \mathrm{~Hz}, 2 \mathrm{H}), 7.28$ (td, $J=12.5,5.8 \mathrm{~Hz}, 6 \mathrm{H}), 6.43(\mathrm{~d}, J=15.8 \mathrm{~Hz}, 1 \mathrm{H}), 5.93(\mathrm{dt}, J=15.8,6.8 \mathrm{~Hz}, 1 \mathrm{H}), 5.74(\mathrm{dt}, J=15.0,7.2 \mathrm{~Hz}$, 1H), 5.62 (dt, $J=15.0,6.5 \mathrm{~Hz}, 1 \mathrm{H}$ ), 3.97 (app. t, $J=7.9 \mathrm{~Hz}, 4 \mathrm{H}$ ), 3.85 (d, $J=6.1 \mathrm{~Hz}, 2 \mathrm{H}$ ), 2.43 (s, 3H); ${ }^{13} \mathrm{C}-$ NMR $\left(101 \mathrm{MHz}, \mathrm{CDCl}_{3}\right): \delta 143.73,137.37,136.33,134.55,130.44,130.04,129.59,128.83,128.23$, 127.47, 126.68, 123.75, 49.57, 48.20, 44.24, 21.77; HR-MS (m/z): [M + $\left.\mathrm{Na}^{+}\right]$calcd for $\mathrm{C}_{20} \mathrm{H}_{22} \mathrm{ClNNaO}_{2} \mathrm{~S}$ : 398.0958; found: 398.0957.

\section{$N$-((E)-4-chlorobut-2-en-1-yl)- $N$-cinnamyl-2-methylpropane-2-sulfonamide (5a)}

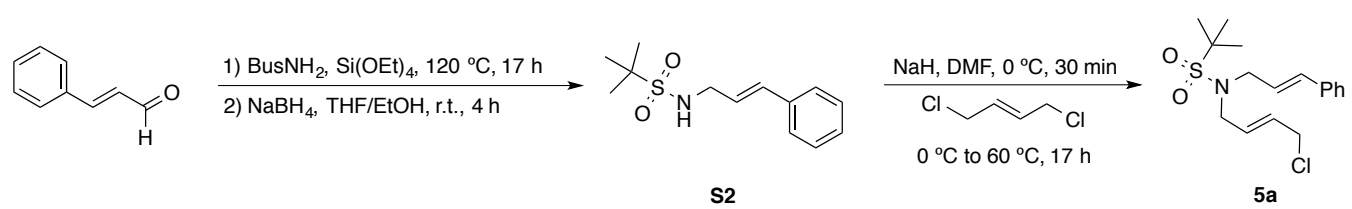

tert-butylsulfonamide (1.37 g, $10 \mathrm{mmol}, 1$ eq.),] and (E)-cinnamaldehyde (1.26 mL, $10 \mathrm{mmol}, 1$ eq.) were added to an oven-dried microwave vial with stir bar and placed under argon. Tetraethyl orthosilicate (2.33 mL, $10.5 \mathrm{mmol}, 1.05$ eq.) was added via syringe and the reaction was heated to 120 degrees for 17 hours. After 17 hours, the reaction was cooled to room temperature, diluted with 9:1 
hexanes:EtOAc and collected via filtration. The imine was dissolved in $100 \mathrm{~mL}$ of 7:1 EtOH/THF and $\mathrm{NaBH}_{4}$ was added (1.13 g, $30 \mathrm{mmol}, 3 \mathrm{eq}$.). The reaction was allowed to stir at room temperature for 4 hours. The reaction was quenched with saturated aqueous ammonium chloride $(30 \mathrm{~mL})$ and the reaction was concentrated in vacuo. The reaction was dissolved in ether $(50 \mathrm{~mL})$ and water $(50 \mathrm{~mL})$. The layers were shaken and separated and the aqueous phase was extracted twice more with ether (20 $\mathrm{mL}$ ). The combined organics were dried over $\mathrm{MgSO}_{4}$, filtered, and concentrated. The crude product was purified via silica gel chromatography (3:1 hexanes:EtOAc) to yield $N$-cinnamyl-2-methylpropane-2sulfonamide $\mathbf{S} 2$ as a yellow-white solid $\left(1.51 \mathrm{~g}, 5.95 \mathrm{mmol}, 60 \%\right.$ yield). [ $\mathrm{R}_{\mathrm{f}}=0.2$ (5:1 hexanes:EtOAc)]; IR (thin film): 3284, 3027, 2976, 2935, 1597, 1494, 1475, 1432, 1396, 1365, 1295, 1207, 1117, 1095, 1073, $1061,1024,963,908,872,823,731,690,663,556,510 \mathrm{~cm}^{-1} ;{ }^{1} \mathrm{H}-\mathrm{NMR}\left(400 \mathrm{MHz} ; \mathrm{CDCl}_{3}\right): \delta$ 7.38-7.25 (m, $5 \mathrm{H}), 6.56(\mathrm{~d}, J=15.8 \mathrm{~Hz}, 1 \mathrm{H}), 6.23(\mathrm{dt}, J=15.8,6.2 \mathrm{~Hz}, 1 \mathrm{H}), 4.14(\mathrm{~s}, 1 \mathrm{H}), 3.95(\mathrm{t}, J=6.2 \mathrm{~Hz}, 2 \mathrm{H}), 1.42(\mathrm{~s}$, 9H); ${ }^{13} \mathrm{C}-\mathrm{NMR}\left(101 \mathrm{MHz}, \mathrm{CDCl}_{3}\right): \delta$ 136.11, 132.54, 128.57, 127.90, 126.43, 125.63, 59.94, 46.80, 24.27; HR-MS (m/z): [M + Na+] calcd for $\mathrm{C}_{13} \mathrm{H}_{19} \mathrm{NNaO}_{2} \mathrm{~S}: 276.1034$; found: 276.1034 .

A flame-dried $25 \mathrm{~mL}$ round-bottomed flask with stir bar was charged with $\mathbf{S 2}$ (1.51 g, 5.95 mmol, 1 eq.) and placed under argon. $29.75 \mathrm{~mL}$ of dry DMF was added via syringe and the solution was cooled to 0 degrees with an ice/water bath. Sodium hydride $(60 \mathrm{wt} \%$ dispersion in mineral oil, $262 \mathrm{mg}$, $6.55 \mathrm{mmol}, 1.1 \mathrm{eq}$.) was added in one portion and the reaction was allowed to stir at 0 degrees for 30 minutes. trans-1,4-dichloro-2-butene $(1.26 \mathrm{~mL}, 12 \mathrm{mmol}, 2 \mathrm{eq}$.) was added rapidly via syringe at 0 degrees. The reaction was taken out of the ice bath and placed in a 60 degree oil bath where it was allowed to stir for 17 hours. After 17 hours, the reaction was cooled to room temperature and $15 \mathrm{~mL}$ of saturated aqueous ammonium chloride was added. The reaction was diluted with ether $(30 \mathrm{~mL})$, the layers were shaken, and separated. The aqueous phase was extracted once with ether $(30 \mathrm{~mL})$. The combined organics were washed with water ( $3 \times 30 \mathrm{~mL}$ ), dried over $\mathrm{MgSO}_{4}$, filtered, and concentrated. Purification by silica gel chromatography (7:1 hexanes:EtOAc) gave $N$ - ((E)-4-chlorobut-2-en-1-yl)- $N$ cinnamyl-2-methylpropane-2-sulfonamide $5 \mathbf{a}$ as a white solid (1.18 g , $3.45 \mathrm{mmol}, 58 \%$ yield). [ $\mathrm{R}_{\mathrm{f}}=0.3$ (5:1 hexanes:EtOAc)]; IR (thin film): 2976, 1496, 1479, 1448, 1366, 1312, 1250, 1124, 1045, 967, 908, 844, 809, 756, 728, 691, 669, 642, 559, $510 \mathrm{~cm}^{-1} ;{ }^{1} \mathrm{H}-\mathrm{NMR}\left(400 \mathrm{MHz} ; \mathrm{CDCl}_{3}\right): \delta 7.40(\mathrm{~d}, J=7.4 \mathrm{~Hz}, 2 \mathrm{H})$, $7.33(\mathrm{t}, J=7.4 \mathrm{~Hz}, 2 \mathrm{H}), 7.28-7.25(\mathrm{~m}, 1 \mathrm{H}), 6.52(\mathrm{~d}, J=15.8 \mathrm{~Hz}, 1 \mathrm{H}), 6.14(\mathrm{dt}, J=15.8,6.8 \mathrm{~Hz}, 1 \mathrm{H}), 5.84-$ $5.74(\mathrm{~m}, 2 \mathrm{H}), 4.06(\mathrm{~d}, J=4.5 \mathrm{~Hz}, 2 \mathrm{H}), 4.02(\mathrm{~d}, J=6.8 \mathrm{~Hz}, 2 \mathrm{H}), 3.91(\mathrm{~d}, J=3.2 \mathrm{~Hz}, 2 \mathrm{H}), 1.42(\mathrm{~s}, 9 \mathrm{H}) ;{ }^{13} \mathrm{C}-\mathrm{NMR}$ (101 MHz, $\mathrm{CDCl}_{3}$ ): $\delta 136.35,134.88,130.86,130.42,128.90,128.31,126.76,124.70,61.61,50.32,48.93$, 44.33, 24.85; HR-MS (m/z): [M + Na+ $]$ calcd for $\mathrm{C}_{17} \mathrm{H}_{24} \mathrm{ClNNaO}_{2} \mathrm{~S}$ : 364.1114; found: 364.1114. 
$N$-(E)-4-chlorobut-2-en-1-yl)- $N$-((E)-3-(4-chlorophenyl)allyl)-2-methylpropane-2-sulfonamide (5b)

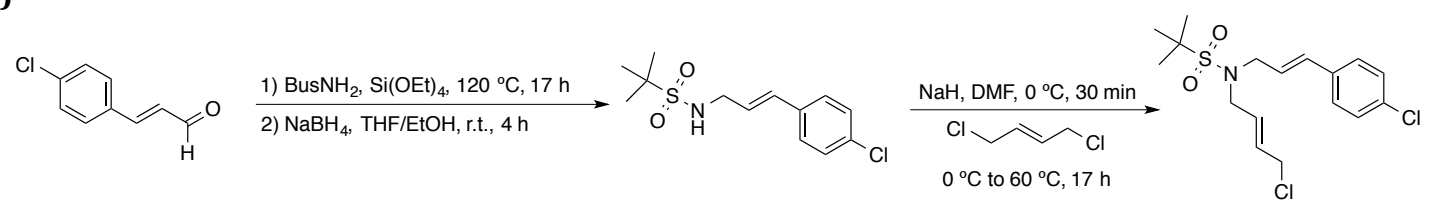

S3

$5 b$

tert-butylsulfonamide (412 mg, $3 \mathrm{mmol}, 1$ eq.),] and (E)-4-chlorocinnamaldehyde (500 mg, 3 mmol, 1 eq.) were added to an oven-dried microwave vial with stir bar and placed under argon. Tetraethyl orthosilicate $(0.7 \mathrm{~mL}, 3.15 \mathrm{mmol}, 1.05 \mathrm{eq}$.) was added via syringe and the reaction was heated to 120 degrees for 17 hours. After 17 hours, the reaction was cooled to room temperature, diluted with 9:1 hexanes:EtOAc and collected via filtration. The imine was dissolved in $26 \mathrm{~mL}$ of 7:1 EtOH/THF and $\mathrm{NaBH}_{4}$ was added $(340 \mathrm{mg}, 9 \mathrm{mmol}, 3$ eq.). The reaction was allowed to stir at room temperature for 4 hours. The reaction was quenched with saturated aqueous ammonium chloride $(10 \mathrm{~mL})$ and the reaction was concentrated in vacuo. The reaction was dissolved in ether $(15 \mathrm{~mL})$ and water $(15 \mathrm{~mL})$. The layers were shaken and separated and the aqueous phase was extracted twice more with ether (5 $\mathrm{mL}$ ). The combined organics were dried over $\mathrm{MgSO}_{4}$, filtered, and concentrated. The crude product was purified via silica gel chromatography (3:1 hexanes:EtOAc) to yield $(E)-N$-(3-(4-chlorophenyl)allyl)-2methylpropane-2-sulfonamide $\mathbf{S} 3$ as a yellow-white solid (374 mg, $1.3 \mathrm{mmol}, 43 \%$ yield). $\left[\mathrm{R}_{\mathrm{f}}=0.19\right.$ (3:1 hexanes:EtOAc)]; IR (thin film): 3282, 2976, 2941, 1489, 1428, 1402, 1366, 1295, 1204, 1129, 1114, 1091, 1058, 1026, 1011, 968, 944, 874, 843, 793, 775, 734, 659, 633, 574, $508 \mathrm{~cm}^{-1}$; ${ }^{1} \mathrm{H}-\mathrm{NMR}$ (400 MHz; $\mathrm{CDCl}_{3}$ ): $\delta 7.27$ (app. s, 4H), $6.50(\mathrm{~d}, J=15.9 \mathrm{~Hz}, 1 \mathrm{H}), 6.23-6.16(\mathrm{~m}, 1 \mathrm{H}), 4.38-4.22(\mathrm{br} \mathrm{s}, 1 \mathrm{H}), 3.95-3.93(\mathrm{~m}$, 2H), 1.41 (s, 9H); ${ }^{13} \mathrm{C}-\mathrm{NMR}\left(101 \mathrm{MHz}, \mathrm{CDCl}_{3}\right): \delta$ 134.93, 133.73, 131.43, 129.00, 127.92, 126.79, 60.24, 46.91, 24.54; HR-MS (m/z): [M + Na+] calcd for $\mathrm{C}_{13} \mathrm{H}_{18} \mathrm{ClNNaO}_{2} \mathrm{~S}$ : 310.0645; found: 310.0645 .

A flame-dried $25 \mathrm{~mL}$ round-bottomed flask with stir bar was charged with $\mathbf{S} 3$ (288 mg, $1 \mathrm{mmol}$, 1 eq.) and placed under argon. $5 \mathrm{~mL}$ of dry DMF was added via syringe and the solution was cooled to 0 degrees with an ice/water bath. Sodium hydride (60 wt\% dispersion in mineral oil, $43 \mathrm{mg}, 1.1 \mathrm{mmol}, 1.1$ eq.) was added in one portion and the reaction was allowed to stir at 0 degrees for 30 minutes. trans-1,4dichloro-2-butene $(0.21 \mathrm{~mL}, 2 \mathrm{mmol}, 2$ eq.) was added rapidly via syringe at 0 degrees. The reaction was taken out of the ice bath and placed in a 60 degree oil bath where it was allowed to stir for 17 hours. After 17 hours, the reaction was cooled to room temperature and $3 \mathrm{~mL}$ of saturated aqueous ammonium chloride was added. The reaction was diluted with ether $(5 \mathrm{~mL})$, the layers were shaken, and separated. The aqueous phase was extracted once with ether $(5 \mathrm{~mL})$. The combined organics were washed with water ( $3 \times 5 \mathrm{~mL}$ ), dried over $\mathrm{MgSO}_{4}$, filtered, and concentrated. Purification by silica gel chromatography (9:1 hexanes:EtOAc) gave $\quad N$-((E)-4-chlorobut-2-en-1-yl)- $N$ - $((E)-3$-(4-chlorophenyl)allyl)-2methylpropane-2-sulfonamide $\mathbf{5 b}$ as a white solid $(233 \mathrm{mg}, 0.62 \mathrm{mmol}, 62 \%$ yield $)$. $\left[\mathrm{R}_{\mathrm{f}}=0.3(5: 1\right.$ hexanes:EtOAc)]; IR (thin film): 2976, 1490, 1442, 1405, 1395, 1365, 1312, 1250, 1204, 1123, 1092, $1012,968,911,854,836,808,748,730,677,639,561,509 \mathrm{~cm}^{-1} ;{ }^{1} \mathrm{H}-\mathrm{NMR}\left(400 \mathrm{MHz} ; \mathrm{CDCl}_{3}\right): \delta 7.29$ 
(app. q, $J=6.7 \mathrm{~Hz}, 4 \mathrm{H}), 6.46(\mathrm{~d}, J=15.8 \mathrm{~Hz}, 1 \mathrm{H}), 6.11(\mathrm{dt}, J=15.8,6.7 \mathrm{~Hz}, 1 \mathrm{H}), 5.82-5.72(\mathrm{~m}, 2 \mathrm{H}), 4.05(\mathrm{~d}, J$ $=4.1 \mathrm{~Hz}, 2 \mathrm{H}), 3.99(\mathrm{~d}, J=6.7 \mathrm{~Hz}, 2 \mathrm{H}), 3.89(\mathrm{~d}, J=3.1 \mathrm{~Hz}, 2 \mathrm{H}), 1.40(\mathrm{~s}, 9 \mathrm{H}) ;{ }^{13} \mathrm{C}-\mathrm{NMR}\left(101 \mathrm{MHz}, \mathrm{CDCl}_{3}\right): \delta$ $134.84,133.88,133.52,130.85,130.38,129.03,127.97,125.53,61.65,50.31,49.07,44.29,24.83$; HR-MS $(\mathrm{m} / \mathrm{z}):\left[\mathrm{M}+\mathrm{Na}^{+}\right]$calcd for $\mathrm{C}_{17} \mathrm{H}_{23} \mathrm{Cl}_{2} \mathrm{NNaO}_{2} \mathrm{~S}: 398.0725$; found: 398.0724 .

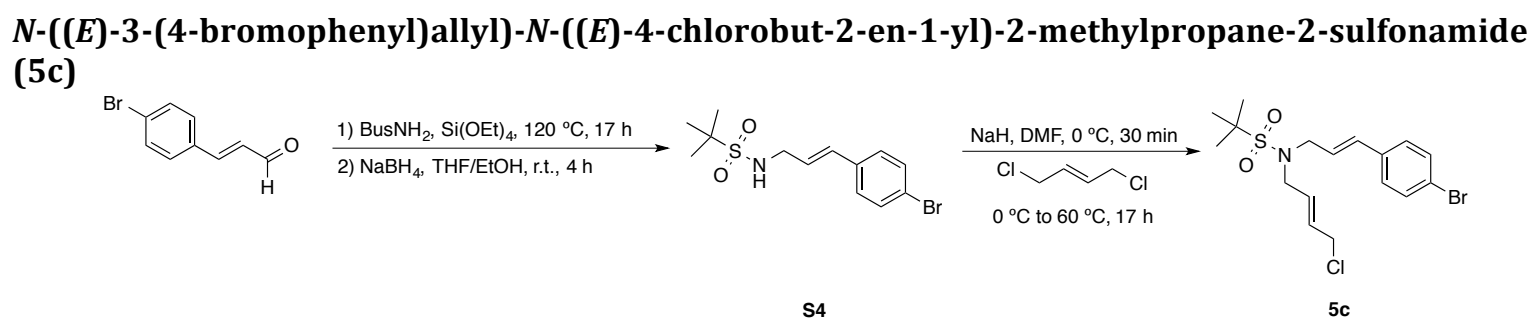

tert-butylsulfonamide (412 mg, $3 \mathrm{mmol}, 1$ eq.),] and (E)-4-bromocinnamaldehyde (633 mg, 3 mmol, 1 eq.) were added to an oven-dried microwave vial with stir bar and placed under argon. Tetraethyl orthosilicate ( $0.7 \mathrm{~mL}, 3.15 \mathrm{mmol}, 1.05$ eq.) was added via syringe and the reaction was heated to 120 degrees for 17 hours. After 17 hours, the reaction was cooled to room temperature, diluted with 9:1 hexanes:EtOAc and collected via filtration. The imine was dissolved in $26 \mathrm{~mL}$ of 7:1 EtOH/THF and $\mathrm{NaBH}_{4}$ was added (340 mg, $9 \mathrm{mmol}, 3$ eq.). The reaction was allowed to stir at room temperature for 4 hours. The reaction was quenched with saturated aqueous ammonium chloride $(10 \mathrm{~mL})$ and the reaction was concentrated in vacuo. The reaction was dissolved in ether (15 mL) and water (15 mL). The layers were shaken and separated and the aqueous phase was extracted twice more with ether (5 $\mathrm{mL}$ ). The combined organics were dried over $\mathrm{MgSO}_{4}$, filtered, and concentrated. The crude product was purified via silica gel chromatography (3:1 hexanes:EtOAc) to yield $(E)-N$-(3-(4-bromophenyl)allyl)-2methylpropane-2-sulfonamide S4 as a yellow-white solid (487 mg, $1.47 \mathrm{mmol}, 49 \%$ yield). [ $\mathrm{R}_{\mathrm{f}}=0.18$ (3:1 hexanes:EtOAc)]; IR (thin film): 3285, 2974, 1485, 1425, 1397, 1365, 1295, 1204, 1113, 1129, 1071, 1058, 1026, 1007, 968, 944, 907, 882, 841, 823, 772, 732, 689, 655, 564, $509 \mathrm{~cm}^{-1}$; ${ }^{1} \mathrm{H}-\mathrm{NMR}$ (400 MHz; $\mathrm{CDCl}_{3}$ ): $\delta 7.43(\mathrm{~d}, J=8.3 \mathrm{~Hz}, 2 \mathrm{H}), 7.22(\mathrm{~d}, J=8.3 \mathrm{~Hz}, 2 \mathrm{H}), 6.49(\mathrm{~d}, J=15.8 \mathrm{~Hz}, 1 \mathrm{H}), 6.21(\mathrm{dt}, J=15.8,6.1$ $\mathrm{Hz}, 1 \mathrm{H}), 4.22(\mathrm{~s}, 1 \mathrm{H}), 3.93(\mathrm{t}, J=6.1 \mathrm{~Hz}, 2 \mathrm{H}), 1.41(\mathrm{~s}, 9 \mathrm{H}) ;{ }^{13} \mathrm{C}-\mathrm{NMR}\left(101 \mathrm{MHz}, \mathrm{CDCl}_{3}\right): \delta$ 135.37, 131.96, 131.53, 128.24, 126.90, 121.95, 60.26, 46.94, 24.54; HR-MS (m/z): $\left[\mathrm{M}+\mathrm{Na}^{+}\right]$calcd for $\mathrm{C}_{13} \mathrm{H}_{18} \mathrm{BrNNaO}_{2} \mathrm{~S}$ : 354.0140; found: 354.0139 .

A flame-dried $25 \mathrm{~mL}$ round-bottomed flask with stir bar was charged with $\mathbf{S 4}(332 \mathrm{mg}, 1 \mathrm{mmol}$, 1 eq.) and placed under argon. $5 \mathrm{~mL}$ of dry DMF was added via syringe and the solution was cooled to 0 degrees with an ice/water bath. Sodium hydride (60 wt\% dispersion in mineral oil, $43 \mathrm{mg}, 1.1 \mathrm{mmol}, 1.1$ eq.) was added in one portion and the reaction was allowed to stir at 0 degrees for 30 minutes. trans-1,4dichloro-2-butene ( $0.21 \mathrm{~mL}, 2 \mathrm{mmol}, 2 \mathrm{eq}$.) was added rapidly via syringe at 0 degrees. The reaction was taken out of the ice bath and placed in a 60 degree oil bath where it was allowed to stir for 17 hours. After 17 hours, the reaction was cooled to room temperature and $3 \mathrm{~mL}$ of saturated aqueous ammonium chloride was added. The reaction was diluted with ether $(5 \mathrm{~mL})$, the layers were shaken, and separated. The aqueous phase was extracted once with ether $(5 \mathrm{~mL})$. The combined organics were washed with 
water ( 3 x $5 \mathrm{~mL}$ ), dried over $\mathrm{MgSO}_{4}$, filtered, and concentrated. Purification by silica gel chromatography (9:1 hexanes:EtOAc) gave $N$-((E)-3-(4-bromophenyl)allyl)- $N$-((E)-4-chlorobut-2-en-1-yl)-2methylpropane-2-sulfonamide $\mathbf{5 c}$ as a white solid $(272 \mathrm{mg}, 0.65 \mathrm{mmol}, 65 \%$ yield $) .\left[\mathrm{R}_{\mathrm{f}}=0.4(3: 1\right.$ hexanes:EtOAc)]; IR (thin film): 2976, 1486, 1442, 1395, 1365, 1312, 1250, 1123, 1071, 1008, 968, 910, 853, 833, 808, 792, 729, 681, 655, 638, 559, $509 \mathrm{~cm}^{-1} ;{ }^{1} \mathrm{H}-\mathrm{NMR}\left(400 \mathrm{MHz} ; \mathrm{CDCl}_{3}\right): \delta 7.44$ (d, $J=8.5 \mathrm{~Hz}$, 2H), $7.25(\mathrm{~d}, J=8.5 \mathrm{~Hz}, 2 \mathrm{H}), 6.45(\mathrm{~d}, J=15.9 \mathrm{~Hz}, 1 \mathrm{H}), 6.13(\mathrm{dt}, J=15.9,6.7 \mathrm{~Hz}, 1 \mathrm{H}), 5.82-5.72(\mathrm{~m}, 2 \mathrm{H})$, $4.06(\mathrm{~d}, J=3.9 \mathrm{~Hz}, 2 \mathrm{H}), 3.99$ (d, $J=6.7 \mathrm{~Hz}, 2 \mathrm{H}), 3.89$ (d, $J=3.1 \mathrm{~Hz}, 2 \mathrm{H}), 1.41(\mathrm{~s}, 9 \mathrm{H}) ;{ }^{13} \mathrm{C}-\mathrm{NMR}(101 \mathrm{MHz}$, $\mathrm{CDCl}_{3}$ ): $\delta$ 135.26, 133.57, 131.98, 130.87, 130.37, 128.27, 125.67, 122.08, 61.66, 50.32, 49.08, 44.29, 24.84; $\mathrm{HR}-\mathrm{MS}(\mathrm{m} / \mathrm{z}):\left[\mathrm{M}+\mathrm{Na}^{+}\right]$calcd for $\mathrm{C}_{17} \mathrm{H}_{23} \mathrm{BrClNNaO}_{2} \mathrm{~S}: 442.0219$; found: 442.0219 .

\section{$N$-((E)-4-chlorobut-2-en-1-yl)- $N$-((E)-3-(4-methoxyphenyl)allyl)-2-methylpropane-2-sulfonamide} (5d)

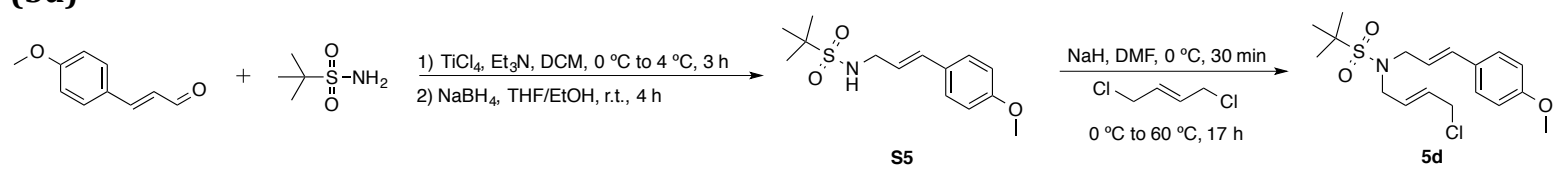

tert-butylsulfonamide (274 mg, $3 \mathrm{mmol}, 1$ eq.), (E)-4-methoxycinnamaldehyde (487 mg, 3 mmol, 1 eq.) were added to a flame dried $25 \mathrm{~mL}$ r.b. flask with stir bar and argon balloon. $9 \mathrm{~mL}$ of DCM and $\mathrm{Et}_{3} \mathrm{~N}$ (0.84 mL, $6 \mathrm{mmol}, 2$ eq.) were added via syringe and the mixture was cooled to 0 degrees with an ice/water bath. $\mathrm{TiCl}_{4}(0.33 \mathrm{~mL}, 3 \mathrm{mmol}, 1 \mathrm{eq}$.) was added and the reaction was allowed to stir at 4 degrees in a cold room for 3 hours. The reaction was then filtered through celite and concentrated. The crude residue was purified via silica gel chromatography (3:1 hex:EtOAc) and reduced directly. The purified product was dissolved in $75 \mathrm{~mL}$ of 7:1 EtOH/THF and $\mathrm{NaBH}_{4}(340 \mathrm{mg}, 9 \mathrm{mmol}, 3 \mathrm{eq}$.) was added. The reaction stirred at room temperature for 4 hours. . The reaction was quenched with saturated aqueous ammonium chloride $(10 \mathrm{~mL})$ and the reaction was concentrated in vacuo. The reaction was dissolved in ether $(15 \mathrm{~mL})$ and water $(15 \mathrm{~mL})$. The layers were shaken and separated and the aqueous phase was extracted twice more with ether $(5 \mathrm{~mL})$. The combined organics were dried over $\mathrm{MgSO}_{4}$, filtered, and concentrated. The crude product was purified via silica gel chromatography (3:1 hexanes:EtOAc) to yield (E)-N-(3-(4-methoxyphenyl)allyl)-2-methylpropane-2-sulfonamide $\mathbf{S 5}$ as a white solid (303 mg, $1.07 \mathrm{mmol}, 36 \%$ yield) [ $\mathrm{R}_{\mathrm{f}}=0.24$ (3:1 Hexanes:EtOAc)]; IR (thin film): 3292, 2959, 2936, 2840, 2360, 2342, 1605, 1575, 1509, 1445, 1397, 1368, 1300, 1270, 1244, 1189, 1174, 1113, $1102,1055,1028,968,909,871,841,828,807,783,758,732,661,601,544,512 \mathrm{~cm}^{-1}$; ${ }^{1} \mathrm{H}-\mathrm{NMR}$ (400 MHz; $\left.\mathrm{CDCl}_{3}\right): \delta 7.29(\mathrm{~d}, J=8.7 \mathrm{~Hz}, 2 \mathrm{H}), 6.84(\mathrm{~d}, J=8.7 \mathrm{~Hz}, 2 \mathrm{H}), 6.49(\mathrm{~d}, J=15.8 \mathrm{~Hz}, 1 \mathrm{H}), 6.07(\mathrm{dt}, J=15.8$, $6.3 \mathrm{~Hz}, 1 \mathrm{H}), 4.19(\mathrm{br} \mathrm{s}, 1 \mathrm{H}), 3.91(\mathrm{t}, J=6.3 \mathrm{~Hz}, 2 \mathrm{H}), 3.80(\mathrm{~s}, 3 \mathrm{H}), 1.41(\mathrm{~s}, 9 \mathrm{H}) ;{ }^{13} \mathrm{C}-\mathrm{NMR}\left(101 \mathrm{MHz}, \mathrm{CDCl}_{3}\right): \delta$ 159.64, 132.38, 129.17, 127.93, 123.64, 114.24, 60.17, 55.53, 47.22, 24.56. HR-MS (m/z): [M + Na+] calcd for $\mathrm{C}_{14} \mathrm{H}_{21} \mathrm{NNaO}_{3} \mathrm{~S}: 306.1140$; found: 306.1140 .

A flame-dried $25 \mathrm{~mL}$ round-bottomed flask with stir bar was charged with $\mathbf{S 5}$ (213 mg, 0.75 mmol, 1 eq.) and placed under argon. $3.75 \mathrm{~mL}$ of dry DMF was added via syringe and the solution was 
cooled to 0 degrees with an ice/water bath. Sodium hydride (60 wt $\%$ dispersion in mineral oil, $33 \mathrm{mg}$, $0.83 \mathrm{mmol}, 1.1 \mathrm{eq}$.) was added in one portion and the reaction was allowed to stir at 0 degrees for 30 minutes. trans-1,4-dichloro-2-butene $(0.16 \mathrm{~mL}, 1.5 \mathrm{mmol}, 2$ eq.) was added rapidly via syringe at 0 degrees. The reaction was taken out of the ice bath and placed in a 60 degree oil bath where it was allowed to stir for 17 hours. After 17 hours, the reaction was cooled to room temperature and $2 \mathrm{~mL}$ of saturated aqueous ammonium chloride was added. The reaction was diluted with ether $(5 \mathrm{~mL})$, the layers were shaken, and separated. The aqueous phase was extracted once with ether $(5 \mathrm{~mL})$. The combined organics were washed with water ( $3 \times 5 \mathrm{~mL}$ ), dried over $\mathrm{MgSO}_{4}$, filtered, and concentrated. Purification by silica gel chromatography (5:1 hexanes:EtOAc) $N-((E)-4$-chlorobut-2-en-1-yl)- $N-((E)-3$ (4-methoxyphenyl)allyl)-2-methylpropane-2-sulfonamide $\mathbf{5 d}$ as a pale yellow oil (179 $\mathrm{mg}, 0.48 \mathrm{mmol}$, $64 \%$ yield). $\left[\mathrm{R}_{\mathrm{f}}=0.36\right.$ (3:1 hexanes:EtOAc)]; IR (thin film): 2972, 2837, 1607, 1510, 1479, 1463, 1442, $1312,1216,1206,1175,1123,1033,967,913,855,839,809,764,740,715,680,642,557,511 \mathrm{~cm}^{-1} ;{ }^{1} \mathrm{H}-$ NMR (400 MHz; $\left.\mathrm{CDCl}_{3}\right): \delta 7.33(\mathrm{~d}, J=8.7 \mathrm{~Hz}, 2 \mathrm{H}), 6.87(\mathrm{~d}, J=8.7 \mathrm{~Hz}, 2 \mathrm{H}), 6.46(\mathrm{~d}, J=15.8 \mathrm{~Hz}, 1 \mathrm{H}), 5.99$ $(\mathrm{dt}, J=15.8,6.9 \mathrm{~Hz}, 1 \mathrm{H}), 5.83-5.73(\mathrm{~m}, 2 \mathrm{H}), 4.07(\mathrm{~d}, J=4.6 \mathrm{~Hz}, 2 \mathrm{H}), 3.99(\mathrm{~d}, J=6.9 \mathrm{~Hz}, 2 \mathrm{H}), 3.90(\mathrm{~d}, J=3.5$ $\mathrm{Hz}, 2 \mathrm{H}), 3.81(\mathrm{~s}, 3 \mathrm{H}), 1.41$ (s, 9H); ${ }^{13} \mathrm{C}-\mathrm{NMR}\left(101 \mathrm{MHz}, \mathrm{CDCl}_{3}\right): \delta$ 159.76, 130.75, 130.50, 129.11, 128.56, 127.97, 122.28, 114.26, 61.57, 55.56, 50.42, 48.79, 44.36, 24.85; HR-MS (m/z): [M + $\left.\mathrm{Na}^{+}\right]$calcd for $\mathrm{C}_{18} \mathrm{H}_{26} \mathrm{ClNNaO}_{3} \mathrm{~S}$ : 394.1220; found: 394.1219 .

\section{$N$-((E)-4-chlorobut-2-en-1-yl)-2-methyl- $N$-((E)-3-(o-tolyl)allyl)propane-2-sulfonamide (5e)}
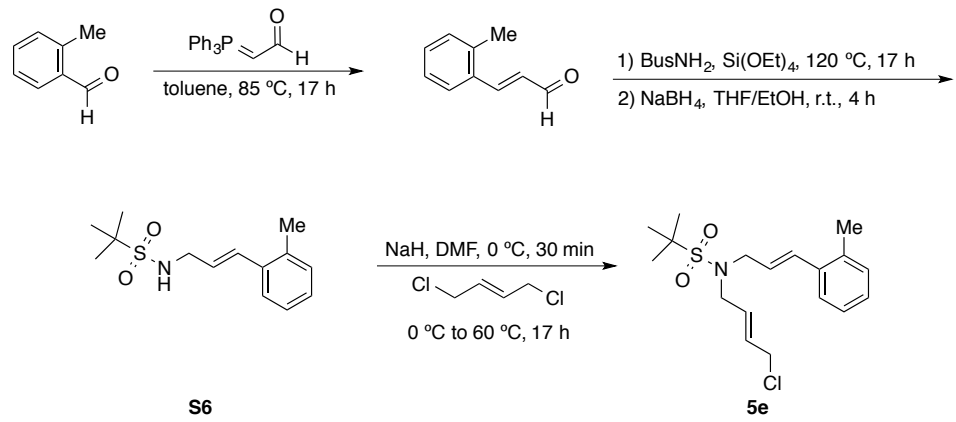

(Triphenylphosphoranylidene)acetaldehyde (1.5 g, $5 \mathrm{mmol}, 1$ eq.), toluene (25 mL), and 2methylbenzaldehyde ( $7.5 \mathrm{mmol}, 1.5$ eq.) were added to a $100 \mathrm{~mL}$ r.b. flask with stir bar. The reaction was heated to 85 degrees for 17 hours. After 15 hours the reaction was cooled, concentrated, and purified via silica gel chromatography (2:1 hex:DCM) to yield (E)-2-methylcinnamaldehyde as a yellow oil (225 mg, $1.54 \mathrm{mmol}, 31 \%$ yield). Spectral data for this compound was consistent with the published literature..$^{\mathrm{iii}}$

tert-butylsulfonamide (211 mg, $1.54 \mathrm{mmol}, 1$ eq.),] and (E)-2-methylcinnamaldehyde (225 mg, $1.54 \mathrm{mmol}, 1$ eq.) were added to an oven-dried microwave vial with stir bar and placed under argon. Tetraethyl orthosilicate $(0.36 \mathrm{~mL}, 1.62 \mathrm{mmol}, 1.05$ eq.) was added via syringe and the reaction was heated to 120 degrees for 17 hours. After 17 hours, the reaction was cooled to room temperature, 
diluted with 9:1 hexanes:EtOAc and collected via filtration. The imine was dissolved in $16 \mathrm{~mL}$ of 7:1 EtOH/THF and $\mathrm{NaBH}_{4}$ was added (171 mg, $4.62 \mathrm{mmol}, 3$ eq.). The reaction was allowed to stir at room temperature for 4 hours. The reaction was quenched with saturated aqueous ammonium chloride 5 $\mathrm{mL})$ and the reaction was concentrated in vacuo. The reaction was dissolved in ether (10 $\mathrm{mL})$ and water $(10 \mathrm{~mL})$. The layers were shaken and separated and the aqueous phase was extracted twice more with ether $(5 \mathrm{~mL})$. The combined organics were dried over $\mathrm{MgSO}_{4}$, filtered, and concentrated. The crude product was purified via silica gel chromatography (3:1 hexanes:EtOAc) to yield $(E)-2$-methyl- $N$ - $(3-(O-$ tolyl)allyl)propane-2-sulfonamide $\mathbf{S} 6$ as a yellow-white solid (209 $\mathrm{mg}, 0.78 \mathrm{mmol}, 51 \%$ yield). [ $\mathrm{R}_{\mathrm{f}}=0.38$ (3:1 hexanes:EtOAc)]; IR (thin film): 3283, 2974, 2359, 2342, 1480, 1456, 1431, 1396, 1365, 1299, 1208, 1122, 1090, 1058 1021, 965, 866, 830, 745, 662, $512 \mathrm{~cm}^{-1}$; ${ }^{1} \mathrm{H}-\mathrm{NMR}\left(400 \mathrm{MHz} ; \mathrm{CDCl}_{3}\right): \delta$ 7.43-7.40 (m, 1H), 7.18-7.13 (m, 3H), $6.79(\mathrm{~d}, J=15.7 \mathrm{~Hz}, 1 \mathrm{H}), 6.11(\mathrm{dt}, J=15.7,5.9 \mathrm{~Hz}, 1 \mathrm{H}), 4.07(\mathrm{br} \mathrm{s}, 1 \mathrm{H}), 3.98(\mathrm{t}, J=$ $5.9 \mathrm{~Hz}, 2 \mathrm{H}), 2.34$ (s, 3H), 1.43 (s, 9H); ${ }^{13} \mathrm{C}-\mathrm{NMR}\left(101 \mathrm{MHz}, \mathrm{CDCl}_{3}\right): \delta$ 135.73, 135.53, 130.73, 130.56, 128.09, 127.20, 126.41, 125.97, 60.21, 47.30, 24.57, 20.04; HR-MS (m/z): $\left[\mathrm{M}+\mathrm{Na}^{+}\right]$calcd for $\mathrm{C}_{14} \mathrm{H}_{21} \mathrm{NNaO}_{2} \mathrm{~S}: 290.1191$; found: 290.1191.

A flame-dried $25 \mathrm{~mL}$ round-bottomed flask with stir bar was charged with $\mathbf{S 6}$ (160 mg, 0.6 mmol, 1 eq.) and placed under argon. $3 \mathrm{~mL}$ of dry DMF was added via syringe and the solution was cooled to 0 degrees with an ice/water bath. Sodium hydride (60 wt\% dispersion in mineral oil, $27 \mathrm{mg}$, $0.66 \mathrm{mmol}, 1.1 \mathrm{eq}$.) was added in one portion and the reaction was allowed to stir at 0 degrees for 30 minutes. trans-1,4-dichloro-2-butene $(0.127 \mathrm{~mL}, 1.2 \mathrm{mmol}, 2$ eq. $)$ was added rapidly via syringe at 0 degrees. The reaction was taken out of the ice bath and placed in a 60 degree oil bath where it was allowed to stir for 17 hours. After 17 hours, the reaction was cooled to room temperature and $3 \mathrm{~mL}$ of saturated aqueous ammonium chloride was added. The reaction was diluted with ether $(5 \mathrm{~mL})$, the layers were shaken, and separated. The aqueous phase was extracted once with ether $(5 \mathrm{~mL})$. The combined organics were washed with water ( $3 \times 5 \mathrm{~mL}$ ), dried over $\mathrm{MgSO}_{4}$, filtered, and concentrated. Purification by silica gel chromatography (9:1 hexanes:EtOAc) gave $N$ - $((E)-4$-chlorobut-2-en-1-yl)-2methyl- $N$ - $((E)$-3-(o-tolyl)allyl)propane-2-sulfonamide $\mathbf{5 e}$ as a yellow oil $(138 \mathrm{mg}, 0.39 \mathrm{mmol}, 65 \%$ yield). [ $\mathrm{R}_{\mathrm{f}}=0.5$ (3:1 hexanes:EtOAc)]; IR (thin film): 2975, 1725, 1480, 1458, 1395, 1365, 1312, 1123, 968, 912, 849, 810, 731, 669, 643, 546, $510 \mathrm{~cm}^{-1} ;{ }^{1} \mathrm{H}-\mathrm{NMR}\left(400 \mathrm{MHz} ; \mathrm{CDCl}_{3}\right): \delta 7.45(\mathrm{t}, J=4.4 \mathrm{~Hz}, 1 \mathrm{H})$, 7.22-7.12 (m, 3H), 6.75 (d, $J=15.4 \mathrm{~Hz}, 1 \mathrm{H}), 6.01(\mathrm{dt}, J=15.4,7.3 \mathrm{~Hz}, 1 \mathrm{H}), 5.85-5.75(\mathrm{~m}, 2 \mathrm{H}), 4.06$ (app. $\mathrm{dd}, J=10.8,5.9 \mathrm{~Hz}, 4 \mathrm{H}), 3.92(\mathrm{~d}, J=3.5 \mathrm{~Hz}, 2 \mathrm{H}), 2.35(\mathrm{~s}, 3 \mathrm{H}), 1.42(\mathrm{~s}, 9 \mathrm{H}) ;{ }^{13} \mathrm{C}-\mathrm{NMR}\left(101 \mathrm{MHz}, \mathrm{CDCl}_{3}\right): \delta$ 135.70, 135.52, 132.69, 130.86, 130.61, 130.49, 128.19, 126.43, 126.01, 125.93, 61.60, 50.31, 48.83, 44.28, 24.83, 20.13; HR-MS (m/z): [M + Na+] calcd for $\mathrm{C}_{18} \mathrm{H}_{26} \mathrm{ClNNaO}_{2} \mathrm{~S}: 378.1271$; found: 378.1270 . 
$N$-((E)-4-chlorobut-2-en-1-yl)-2-methyl- $N$-((E)-3-phenylbut-2-en-1-yl)propane-2-sulfonamide (5f)

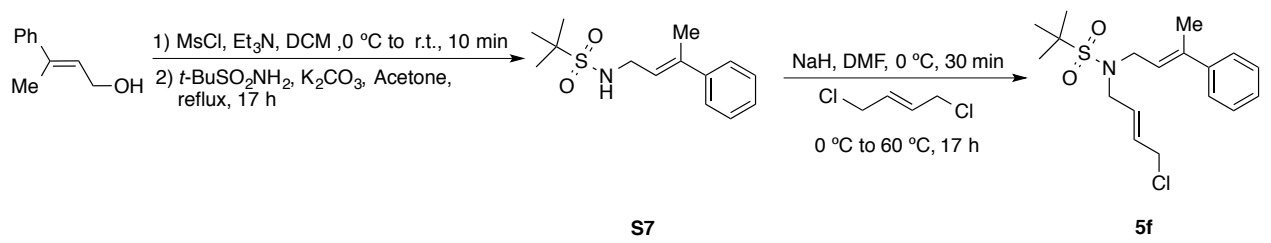

A flame-dried $25 \mathrm{~mL}$ round bottom flask with stir bar was charged with alcohol $(445 \mathrm{mg}, 3$ mmol, 1 eq.) and placed under argon. $7.7 \mathrm{~mL}$ of DCM and $\mathrm{Et}_{3} \mathrm{~N}(0.63 \mathrm{~mL}, 4.5 \mathrm{mmol}, 1.5$ eq.) was added and the reaction was cooled to 0 degrees. $\mathrm{MsCl}(0.28 \mathrm{~mL}, 3.6 \mathrm{mmol}, 1.2 \mathrm{eq}$.) was added dropwise and the reaction was warmed to room temperature. After $10 \mathrm{~min}$, the reaction was quenched with sat. aq. ammonium chloride $(5 \mathrm{~mL})$, the layers were shaken, and separated. The aqueous phase was washed with DCM $(5 \mathrm{~mL})$ and the combined organics were washed with water $(5 \mathrm{~mL})$, dried over $\mathrm{MgSO}_{4}$, filtered, and concentrated. The crude material was used without purification. The crude mesylate was dissolved in $20 \mathrm{~mL}$ of acetone and $\mathrm{K}_{2} \mathrm{CO}_{3}$ (829 mg, $6 \mathrm{mmol}, 2$ eq.) and tert-butylsulfonamide (494 mg, $3.5 \mathrm{mmol}$, 1.2 eq.) was added. The reaction was brought to reflux and stirred overnight. The reaction was then concentrated in vacuo and purified by silica gel chromatography (3:1 hex:EtOAc) to yield (E)-2-methyl$\mathrm{N}$-(3-phenylbut-2-en-1-yl)propane-2-sulfonamide $\mathbf{S 7}$ as a white solid (157 mg, $0.58 \mathrm{mmol}, 19 \%$ yield). $\left[\mathrm{R}_{\mathrm{f}}=0.36\right.$ (3:1 hexanes:EtOAc)]; IR (thin film): 3289, 2983, 1598, 1494, 1476, 1429, 1397, 1366, 1295, 1116, 1090, 1043, 1026, 994, 942, 909, 868, 837, 756, 744, 693, 661, 547, $512 \mathrm{~cm}^{-1}$; ${ }^{1} \mathrm{H}-\mathrm{NMR}$ (400 MHz; $\left.\mathrm{CDCl}_{3}\right): \delta$ 7.39-7.25 (m, 5H), $5.81(\mathrm{t}, J=6.7 \mathrm{~Hz}, 1 \mathrm{H}), 4.17(\mathrm{br} \mathrm{s}, 1 \mathrm{H}), 3.98(\mathrm{t}, J=6.7 \mathrm{~Hz}, 2 \mathrm{H}), 2.08(\mathrm{~s}, 3 \mathrm{H})$, 1.42 (s, 9H); ${ }^{13} \mathrm{C}-\mathrm{NMR}\left(101 \mathrm{MHz}, \mathrm{CDCl}_{3}\right): \delta$ 142.79, 139.03, 128.56, 127.70, 126.02, 123.75, 60.15, 43.12, 24.56, 16.33; HR-MS (m/z): [M + Na+] calcd for $\mathrm{C}_{14} \mathrm{H}_{21} \mathrm{NNaO}_{2} \mathrm{~S}: 290.1191$; found: 290.1191 .

A flame-dried $25 \mathrm{~mL}$ round-bottomed flask with stir bar was charged with $\mathbf{S 7}$ (107 mg, 0.4 mmol, 1 eq.) and placed under argon. $2 \mathrm{~mL}$ of dry DMF was added via syringe and the solution was cooled to 0 degrees with an ice/water bath. Sodium hydride $(60 \mathrm{wt} \%$ dispersion in mineral oil, $18 \mathrm{mg}$, $0.44 \mathrm{mmol}, 1.1 \mathrm{eq}$.) was added in one portion and the reaction was allowed to stir at 0 degrees for 30 minutes. trans-1,4-dichloro-2-butene $(0.085 \mathrm{~mL}, 0.8 \mathrm{mmol}, 2$ eq. $)$ was added rapidly via syringe at 0 degrees. The reaction was taken out of the ice bath and placed in a 60 degree oil bath where it was allowed to stir for 17 hours. After 17 hours, the reaction was cooled to room temperature and $3 \mathrm{~mL}$ of saturated aqueous ammonium chloride was added. The reaction was diluted with ether $(5 \mathrm{~mL})$, the layers were shaken, and separated. The aqueous phase was extracted once with ether $(5 \mathrm{~mL})$. The combined organics were washed with water ( $3 \times 5 \mathrm{~mL}$ ), dried over $\mathrm{MgSO}_{4}$, filtered, and concentrated. Purification by silica gel chromatography (5:1 hexanes:EtOAc) yielded $N$ - $((E)$-4-chlorobut-2-en-1-yl)-2methyl- $N$ - $((E)$-3-phenylbut-2-en-1-yl)propane-2-sulfonamide $\mathbf{5 f}$ as a pale yellow oil (100 $\mathrm{mg}, 0.28$ mmol, 70\% yield). [ $\mathrm{R}_{\mathrm{f}}=0.49$ (3:1 hexanes:EtOAc)]; IR (thin film): 2982, 1494, 1480, 1445, 1394, 1365, 1312, 1125, 1045, 1025, 971, 915, 810, 752, 735, 698, 645, 595, 546, $511 \mathrm{~cm}^{-1}$; ${ }^{1} \mathrm{H}-\mathrm{NMR}$ (400 MHz; $\mathrm{CDCl}_{3}$ ): $\delta$ 7.40-7.28 (m, 5H), 5.83-5.75 (m, 3H), 4.06 (app. t, $\left.J=6.3 \mathrm{~Hz}, 4 \mathrm{H}\right), 3.90(\mathrm{~d}, J=4.8 \mathrm{~Hz}, 2 \mathrm{H}), 2.04$ 
(s, 3H), 1.41 (s, 9H); ${ }^{13} \mathrm{C}-\mathrm{NMR}\left(101 \mathrm{MHz}, \mathrm{CDCl}_{3}\right): \delta$ 142.98, 139.40, 130.79, 130.45, 128.59, 127.70, 126.01, 123.43, 61.59, 49.36, 46.27, 44.24, 24.82, 16.52; HR-MS (m/z): $\left[\mathrm{M}+\mathrm{Na}^{+}\right]$calcd for $\mathrm{C}_{18} \mathrm{H}_{26} \mathrm{ClNNaO}_{2} \mathrm{~S}$ : 378.1271; found: 378.1270 .

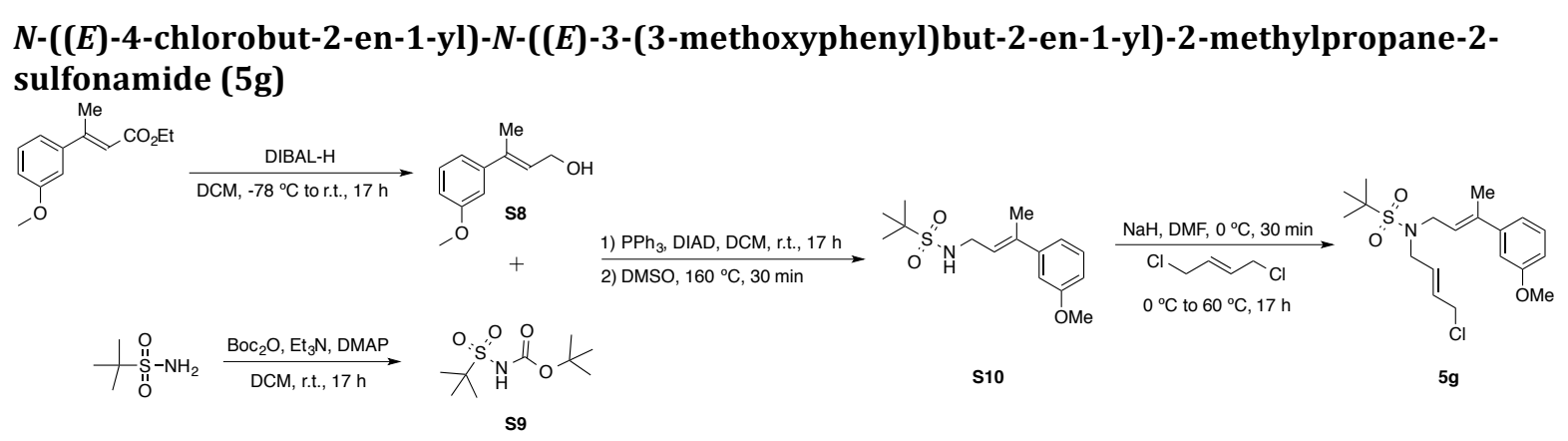

ethyl (E)-3-(3-methoxyphenyl)but-2-enoate ${ }^{\text {iv }}(1.21 \mathrm{~g}, 5.5 \mathrm{mmol}, 1 \mathrm{eq}$.) was added to a flame dried $100 \mathrm{~mL}$ round bottom flask with stir bar and placed under argon. $18 \mathrm{~mL}$ of DCM was added and the reaction was cooled to -78 degrees. $11.46 \mathrm{~mL}$ of DIBAL (13.75 mmol, 2.5 eq.) was added dropwise and the reaction was allowed to warm to rom temperature over 17 hours. After 17 hours, $1 \mathrm{~mL}$ of water, $2 \mathrm{~mL}$ of $\mathrm{NaOH}$, and $1 \mathrm{~mL}$ of water was added successively and the reaction was allowed to stir for 30 minutes. Magnesium sulfate was added to dry and the reaction was filtered over celite. The reaction was concentrated in vacuo and determined to be sufficiently pure for the next reaction. (E)-3-(3methoxyphenyl)but-2-en-1-ol S8 (872 mg, 4.9 mmol, 89\% yield). [ $\mathrm{R}_{\mathrm{f}}=0.13$ (3:1 hexanes:EtOAc)]; IR (thin film): 3324, 2920, 1648, 1598, 1577, 1484, 1450, 1428, 1378, 1320, 1287, 1207, 1172, 1104, 1041, 995, 856, 776, 693, $568 \mathrm{~cm}^{-1}$; ${ }^{1} \mathrm{H}-\mathrm{NMR}\left(400 \mathrm{MHz}^{\left.-C_{D C l}\right)}\right): \delta .23(\mathrm{t}, J=8.1 \mathrm{~Hz}, 1 \mathrm{H}), 7.00(\mathrm{~d}, J=7.7 \mathrm{~Hz}, 1 \mathrm{H})$, $6.95(\mathrm{t}, J=2.3 \mathrm{~Hz}, 1 \mathrm{H}), 6.81(\mathrm{dd}, J=8.1,2.3 \mathrm{~Hz}, 1 \mathrm{H}), 5.97(\mathrm{t}, J=6.6 \mathrm{~Hz}, 1 \mathrm{H}), 4.34(\mathrm{~d}, J=6.6 \mathrm{~Hz}, 2 \mathrm{H}), 3.80(\mathrm{~s}$, 3H), 2.57-2.54 (br, 1H), 2.04 (s, 3H); ${ }^{13} \mathrm{C}-\mathrm{NMR}\left(101 \mathrm{MHz}, \mathrm{CDCl}_{3}\right): \delta$ 159.69, 144.66, 137.58, 129.46, 127.03, 118.58, 112.74, 111.90, 60.02, 55.45, 16.30; HR-MS (m/z): [M] calcd for $\mathrm{C}_{11} \mathrm{H}_{14} \mathrm{O}_{2}$ : 178.0994; found: 178.0994.

tert-butylsulfonamide ( $1 \mathrm{~g}, 7.29 \mathrm{mmol}, 1$ eq.) was added to a $25 \mathrm{~mL}$ round bottom flask with stir bar and dissolved in $9 \mathrm{~mL}$ of dichloromethane. di-tert-butyl-dicarbonate (1.91 g, $8.75 \mathrm{mmol}, 1.2 \mathrm{eq}$.), $\mathrm{Et}_{3} \mathrm{~N}$ (1.52 mL, $10.94 \mathrm{mmol}, 1.5 \mathrm{eq}$.), and dimethylaminopyridine (a chip) were added successively. The resulting solution was stirred at room temperature for 17 hours and subsequently evaporated to near dryness. The residue was diluted with EtOAc $(20 \mathrm{~mL})$, washed with $1 \mathrm{~N}$ aq. $\mathrm{HCl}(3 \times 5 \mathrm{~mL})$ and brine (1x 5 $\mathrm{mL}$ ), dried over $\mathrm{MgSO}_{4}$, filtered, and concentrated in vacuo to provide tert-butyl (tertbutylsulfonyl)carbamate $\mathbf{S 9}$ (1.61 g, $6.78 \mathrm{mmol}$, 93\% yield). IR (thin film): 3166, 3081, 2981, 2940, 1699, 1474, 1455, 1432, 1394, 1369, 1350, 1327, 1260, 1154, 1127, 1067, 1021, 894, 831, 778, 734, 669, 636, 576, $513 \mathrm{~cm}^{-1} ;{ }^{1} \mathrm{H}-\mathrm{NMR}\left(400 \mathrm{MHz} ; \mathrm{CDCl}_{3}\right.$ ): $\delta$ 7.12-7.02 (br, $\left.1 \mathrm{H}\right), 1.48(\mathrm{~s}, 9 \mathrm{H}), 1.47(\mathrm{~s}, 9 \mathrm{H}) ;{ }^{13} \mathrm{C}-\mathrm{NMR}(101$ $\mathrm{MHz}, \mathrm{CDCl}_{3}$ ): $\delta$ 84.04, 62.29, 28.14, 24.67; HR-MS (m/z): [M+ Na+] calcd for $\mathrm{C}_{9} \mathrm{H}_{19} \mathrm{NNaO}_{4} \mathrm{~S}: 260.0933$; found: 260.0933 . 
S8 (356 mg, 2 mmol, 1 eq.), $\mathrm{PPh}_{3}$ (525 mg, 2 mmol, 1 eq.), $\mathbf{S 9}$ (475 mg, 2 mmol, 1 eq.), and DCM (4 $\mathrm{mL}$ ) were added to a $25 \mathrm{~mL}$ flask with stir bar and argon balloon. DIAD (0.39 mL, $2 \mathrm{mmol}, 1$ eq.) was added dropwise via syringe and the reaction stirred at r.t. for 17 hours. After 17 hours, the reaction was concentrated and purified via silica gel chromatography (5:1 hexanes:EtOAc). A portion of the purified product (358 mg, $0.9 \mathrm{mmol}, 1$ eq.) was added to a flame dried $25 \mathrm{~mL}$ round bottom flask with stir bar where it was dissolved in $4.5 \mathrm{~mL}$ of anhydrous DMSO and heated to 160 degrees in a preheated oil bath for 30 minutes. The reaction was cooled to room temperature, diluted with ether $(10 \mathrm{~mL})$ and water $(10$ $\mathrm{mL})$. The layers were shaken, separated, and the organic phase was washed with water $(3 \times 10 \mathrm{~mL})$. The organic layer was dried over $\mathrm{MgSO}_{4}$, filtered, and concentrated. The crude material was purified via silica gel chromatography (3:1 hex:EtOAc) to yield (E)- $N$-(3-(3-methoxyphenyl)but-2-en-1-yl)-2methylpropane-2-sulfonamide $\mathbf{S 1 0}$ as a clear oil $\left(132 \mathrm{mg}, 0.44 \mathrm{mmol}, 24 \%\right.$ yield). [ $\mathrm{R}_{\mathrm{f}}=0.28$ (3:1 hexanes:EtOAc)]; IR (thin film): 3282, 2972, 1737, 1599, 1578, 1483, 1453, 1428, 1396, 1365, 1289, 1208, 1176, 1123, 1041, 847, 779, 696, 651, 567, $512 \mathrm{~cm}^{-1} ;{ }^{1} \mathrm{H}-\mathrm{NMR}\left(400 \mathrm{MHz} ; \mathrm{CDCl}_{3}\right): \delta 7.25$ (t, J = 7.8 $\mathrm{Hz}, 2 \mathrm{H}), 6.97(\mathrm{~d}, J=7.8 \mathrm{~Hz}, 1 \mathrm{H}), 6.90(\mathrm{t}, J=2.0 \mathrm{~Hz}, 1 \mathrm{H}), 6.82(\mathrm{dd}, J=7.9,2.0 \mathrm{~Hz}, 1 \mathrm{H}), 5.81(\mathrm{t}, J=6.8 \mathrm{~Hz}$, $1 \mathrm{H}), 3.97(\mathrm{~m}, J=6.5 \mathrm{~Hz}, 3 \mathrm{H}), 3.82(\mathrm{~s}, 3 \mathrm{H}), 2.06(\mathrm{~s}, 3 \mathrm{H}), 1.41(\mathrm{~s}, 9 \mathrm{H}) ;{ }^{13} \mathrm{C}-\mathrm{NMR}\left(101 \mathrm{MHz}, \mathrm{CDCl}_{3}\right): \delta 159.75$, $144.33,139.05,129.53,123.81,118.55,112.87,112.02$, 60.18, 55.50, 43.11, 24.56, 16.42; HR-MS (m/z): $\left[\mathrm{M}+\mathrm{Na}^{+}\right]$calcd for $\mathrm{C}_{15} \mathrm{H}_{23} \mathrm{NNaO}_{3} \mathrm{~S}: 320.1297$; found: 320.1296 .

A flame-dried $25 \mathrm{~mL}$ round-bottomed flask with stir bar was charged with $\mathbf{S 1 0}$ (253 $\mathrm{mg}, 0.4$ mmol, 1 eq.) and placed under argon. $2 \mathrm{~mL}$ of dry DMF was added via syringe and the solution was cooled to 0 degrees with an ice/water bath. Sodium hydride $(60 \mathrm{wt} \%$ dispersion in mineral oil, $18 \mathrm{mg}$, $0.44 \mathrm{mmol}, 1.1$ eq.) was added in one portion and the reaction was allowed to stir at 0 degrees for 30 minutes. trans-1,4-dichloro-2-butene $(0.085 \mathrm{~mL}, 0.8 \mathrm{mmol}, 2$ eq.) was added rapidly via syringe at 0 degrees. The reaction was taken out of the ice bath and placed in a 60 degree oil bath where it was allowed to stir for 17 hours. After 17 hours, the reaction was cooled to room temperature and $3 \mathrm{~mL}$ of saturated aqueous ammonium chloride was added. The reaction was diluted with ether $(5 \mathrm{~mL})$, the layers were shaken, and separated. The aqueous phase was extracted once with ether $(5 \mathrm{~mL})$. The combined organics were washed with water ( $3 \times 5 \mathrm{~mL}$ ), dried over $\mathrm{MgSO}_{4}$, filtered, and concentrated. Purification by silica gel chromatography (4:1 hexanes:EtOAc) yielded $N$ - ( (E)-4-chlorobut-2-en-1-yl)- $N$ ((E)-3-(3-methoxyphenyl)but-2-en-1-yl)-2-methylpropane-2-sulfonamide $\mathbf{5 g}$ as a clear oil (50 $\mathrm{mg}, 0.13$ mmol, 33\% yield). [ $\mathrm{R}_{\mathrm{f}}=0.28$ (3:1 hexanes:EtOAc)]; IR (thin film): 2916, 1599, 1578, 1483, 1430, 1394, $1365,1312,1288,1210,1176,1125,1042,970,917,874,810,780,758,695,645,547,511 \mathrm{~cm}^{-1} ;{ }^{1} \mathrm{H}-$ $\operatorname{NMR}\left(400 \mathrm{MHz} ; \mathrm{CDCl}_{3}\right): \delta 7.28-7.24(\mathrm{~m}, 1 \mathrm{H}), 6.98(\mathrm{~d}, J=8.4 \mathrm{~Hz}, 1 \mathrm{H}), 6.91(\mathrm{t}, J=2.1 \mathrm{~Hz}, 1 \mathrm{H}), 6.83(\mathrm{dd}, J=$ 8.0, $2.1 \mathrm{~Hz}, 1 \mathrm{H}$ ), 5.85-5.74 (m, 3H), 4.06 (app. dd, J = 6.0, 3.9 Hz, 4H), 3.89 (d, J = 4.7 Hz, 2H), 3.83 (s, 3H), 2.03 (s, 3H), 1.41 (s, 9H); ${ }^{13} \mathrm{C}-\mathrm{NMR}\left(101 \mathrm{MHz}, \mathrm{CDCl}_{3}\right): \delta$ 159.76, 144.58, 139.25, 130.75, 130.48, 129.55, $123.61,118.55,112.56,112.24,61.59,55.53,49.37,46.22,44.22,24.81,16.60 ; \mathrm{HR}-\mathrm{MS}(\mathrm{m} / \mathrm{z}):\left[\mathrm{M}+\mathrm{Na}^{+}\right]$ calcd for $\mathrm{C}_{19} \mathrm{H}_{28} \mathrm{ClNNaO}_{3} \mathrm{~S}: 408.1376$; found: 408.1376 . 


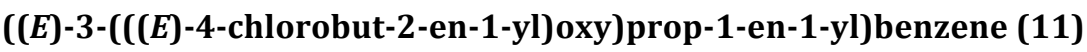

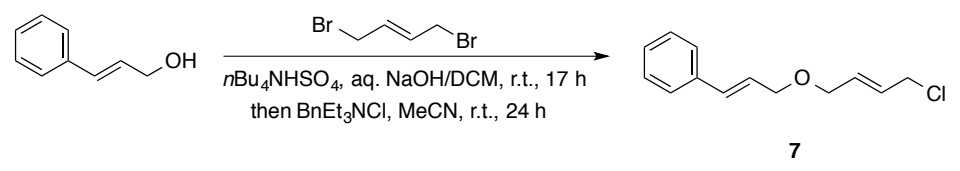

A $2.0 \mathrm{M}$ aqueous solution of $\mathrm{NaOH}(0.9 \mathrm{~mL}, 1.8 \mathrm{mmol}, 0.9$ eq. $)$ was added to a solution of trans1,4- dibromo-2-butene (385 mg, $1.8 \mathrm{mmol}, 0.9$ eq.) and $\mathrm{NBu}_{4} \mathrm{HSO}_{4}\left(61 \mathrm{mg}, 0.18 \mathrm{mmol}, 0.1\right.$ eq.) in $\mathrm{CH}_{2} \mathrm{Cl}_{2}$ (1.5 mL). (E)-cinnamyl alcohol $(0.256 \mathrm{~mL}, 2 \mathrm{mmol}, 1$ eq.) was added dropwise over a period of 5 minutes and the reaction mixture was stirred for 16 hours. The mixture was diluted with distilled water $(10 \mathrm{~mL})$, shaken, and separated. The aqueous layer was extracted with $\mathrm{CH}_{2} \mathrm{Cl}_{2}(3 \times 10 \mathrm{~mL})$ and the combined organics were dried over $\mathrm{MgSO}_{4}$, filtered, and concentrated in vacuo. The, the crude mixture was dissolved in $4 \mathrm{~mL}$ of MeCN and benzyltriethylammonium chloride (2.05 g, $9 \mathrm{mmol}, 5 \mathrm{eq}$.) was added and the reaction was stirred at room temperature for $24 \mathrm{~h}$. After 24 hours, the reaction was concentrated in vacuo, diluted with ether, and filtered. The crude oil was purified via silica gel chromatography (15:1 hex:EtOAc) to yield ((E)-3-(((E)-4-chlorobut-2-en-1-yl)oxy)prop-1-en-1-yl)benzene 7 as a light yellow oil (163 mg, $0.73 \mathrm{mmol}, 37 \%$ yield). [ $\mathrm{R}_{\mathrm{f}}=0.45$ (3:1 hexanes:EtOAc)]; IR (thin film): 3025, 2848, 1674, 1598, 1578, 1494, 1359, 1294, 1249, 1110, 1054, 963, 735, 691, 546, $495 \mathrm{~cm}^{-1} ;{ }^{1} \mathrm{H}-\mathrm{NMR}\left(400 \mathrm{MHz} ; \mathrm{CDCl}_{3}\right): \delta$ $7.41(\mathrm{~d}, J=7.2 \mathrm{~Hz}, 2 \mathrm{H}), 7.33(\mathrm{t}, J=7.4 \mathrm{~Hz}, 2 \mathrm{H}), 7.26(\mathrm{t}, J=7.2 \mathrm{~Hz}, 1 \mathrm{H}), 6.63(\mathrm{~d}, J=15.9 \mathrm{~Hz}, 1 \mathrm{H}), 6.30(\mathrm{dt}, J=$ 15.9, $6.1 \mathrm{~Hz}, 1 \mathrm{H}), 5.96-5.91(\mathrm{~m}, 2 \mathrm{H}), 4.17(\mathrm{dd}, J=6.1,1.3 \mathrm{~Hz}, 2 \mathrm{H}), 4.10-4.08(\mathrm{~m}, 2 \mathrm{H}), 4.06(\mathrm{~d}, J=3.3 \mathrm{~Hz}$, 2H); ${ }^{13} \mathrm{C}-\mathrm{NMR}\left(101 \mathrm{MHz}, \mathrm{CDCl}_{3}\right): \delta 136.82,132.92,131.41,128.83,128.65,128.00,126.74,125.96$, 71.21, 69.67, 44.66; HR-MS (m/z): $\left[\mathrm{M}+\mathrm{NH}_{4}^{+}\right]$calcd for $\mathrm{C}_{13} \mathrm{H}_{14} \mathrm{NClO}: 240.1155$; found: 240.1155 .

\section{dibenzyl (E)-2-(4-chlorobut-2-en-1-yl)-2-(3-methylbut-2-en-1-yl)malonate (9)}

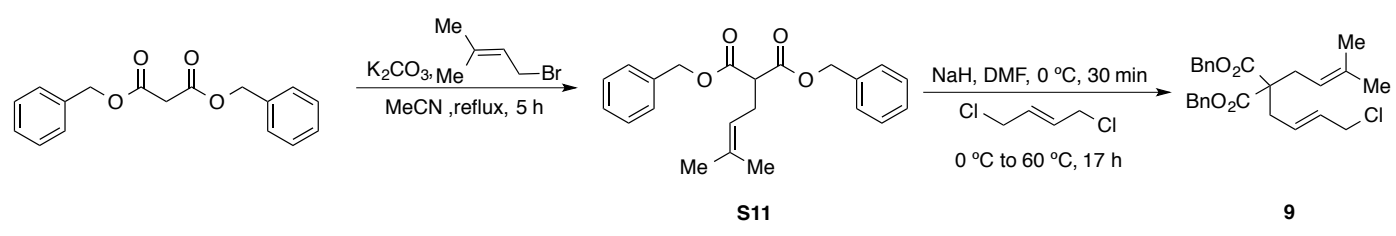

1-bromo-3-methyl-2-butene (2.1 mL, $18.17 \mathrm{mmol}, 1.2 \mathrm{eq}$.) was added to a $100 \mathrm{~mL}$ round bottom flask with stir bar and reflux condenser containing dibenzyl malonate $(3.79 \mathrm{~mL}, 15.14 \mathrm{mmol}, 1$ eq.), $\mathrm{K}_{2} \mathrm{CO}_{3}$ (4.18 g, $30.28 \mathrm{mmol}$, 2 eq.), and MeCN (30 mL). The mixture was stirred at reflux for $5 \mathrm{~h}$. The reaction was cooled to room temperature, the $\mathrm{K}_{2} \mathrm{CO}_{3}$ was filtered off, and the solvent was removed in vacuo. The residue was submitted to flash chromatography (9:1 hexanes:EtOAc) to give dibenzyl 2-(3methylbut-2-en-1-yl)malonate $\mathbf{S 1 1}$ as a yellow oil $\left(2.67 \mathrm{~g}, 7.57 \mathrm{mmol}, 50 \%\right.$ yield). $\left[\mathrm{R}_{\mathrm{f}}=0.45\right.$ (3:1 hexanes:EtOAc)]; IR (thin film): 3034, 2965, 1731, 1498, 1455, 1377, 1331, 1266, 1211, 1141, 1027, 909, 825, 781, 732, 695, $599 \mathrm{~cm}^{-1} ;{ }^{1} \mathrm{H}-\mathrm{NMR}\left(400 \mathrm{MHz} ; \mathrm{CDCl}_{3}\right): \delta$ 7.37-7.30 (m, 10H), $5.18(\mathrm{~s}, 4 \mathrm{H}), 5.08(\mathrm{t}, J=7.3 \mathrm{~Hz}$, 
1H), 3.50 (t, $J=7.7 \mathrm{~Hz}, 1 \mathrm{H}$ ), 2.68 (app. t, $J=7.4 \mathrm{~Hz}, 2 \mathrm{H}$ ), $1.68(\mathrm{~s}, 3 \mathrm{H}), 1.61(\mathrm{~s}, 3 \mathrm{H}) ;{ }^{13} \mathrm{C}-\mathrm{NMR}(101 \mathrm{MHz}$, $\left.\mathrm{CDCl}_{3}\right): \delta 169.20,135.71,135.40,128.80,128.55,128.42,119.71,67.27,52.43,27.89,26.03,18.03$; HRMS (m/z): $\left[\mathrm{M}+\mathrm{Na}^{+}\right]$calcd for $\mathrm{C}_{22} \mathrm{H}_{24} \mathrm{NaO}_{4}: 375.1573$; found: 375.1572 .

A flame-dried $25 \mathrm{~mL}$ round-bottomed flask with stir bar was charged with $\mathbf{S 1 1}$ (352 mg, 1 mmol, 1 eq.) and placed under argon. $5 \mathrm{~mL}$ of dry DMF was added via syringe and the solution was cooled to 0 degrees with an ice/water bath. Sodium hydride $(60 \mathrm{wt} \%$ dispersion in mineral oil, $43 \mathrm{mg}$, $1.1 \mathrm{mmol}, 1.1 \mathrm{eq}$.) was added in one portion and the reaction was allowed to stir at 0 degrees for 30 minutes. trans-1,4-dichloro-2-butene $(0.211 \mathrm{~mL}, 2 \mathrm{mmol}, 2$ eq. $)$ was added rapidly via syringe at 0 degrees. The reaction was taken out of the ice bath and placed in a 60 degree oil bath where it was allowed to stir for 17 hours. After 17 hours, the reaction was cooled to room temperature and $3 \mathrm{~mL}$ of saturated aqueous ammonium chloride was added. The reaction was diluted with ether (5 mL), the layers were shaken, and separated. The aqueous phase was extracted once with ether $(5 \mathrm{~mL})$. The combined organics were washed with water ( $3 \times 5 \mathrm{~mL}$ ), dried over $\mathrm{MgSO}_{4}$, filtered, and concentrated. Purification by silica gel chromatography (15:1 hexanes:EtOAc) yielded dibenzyl (E)-2-(4-chlorobut-2en-1-yl)-2-(3-methylbut-2-en-1-yl)malonate 9 as a clear liquid $\left(277 \mathrm{mg}, 0.63 \mathrm{mmol}, 63 \%\right.$ yield). [ $\mathrm{R}_{\mathrm{f}}=$ 0.3 (3:1 hexanes:EtOAc)]; IR (thin film): 3034, 2963, 1729, 1498, 1455, 1376, 1278, 1255, 1215, 1193, 1158, 1093, 1055, 1029, 1003, 969, 905, 748, 696, $602 \mathrm{~cm}^{-1}$; ${ }^{1} \mathrm{H}-\mathrm{NMR}\left(400 \mathrm{MHz}\right.$; $\left.\mathrm{CDCl}_{3}\right): \delta$ 7.34-7.26 (m, $10 \mathrm{H}), 5.59-5.49(\mathrm{~m}, 2 \mathrm{H}), 5.11(\mathrm{q}, J=10.1 \mathrm{~Hz}, 4 \mathrm{H}), 4.88(\mathrm{t}, J=7.4 \mathrm{~Hz}, 1 \mathrm{H}), 3.87(\mathrm{~d}, J=5.5 \mathrm{~Hz}, 2 \mathrm{H}), 2.63$ (app. t, $J=5.5 \mathrm{~Hz}, 4 \mathrm{H}), 1.64(\mathrm{~s}, 3 \mathrm{H}), 1.55$ (s, 3H); ${ }^{13} \mathrm{C}-\mathrm{NMR}\left(101 \mathrm{MHz}, \mathrm{CDCl}_{3}\right): \delta 170.84,136.32,135.60$, $130.54,129.45,128.75,128.62,128.58,117.33,67.29,58.00,44.89,35.39,31.51,26.25,18.29$; HR-MS $(\mathrm{m} / \mathrm{z}):\left[\mathrm{M}+\mathrm{Na}^{+}\right]$calcd for $\mathrm{C}_{26} \mathrm{H}_{29} \mathrm{ClNaO}_{4}: 463.1652$; found: 463.1652 .

\section{(E)-(1-chloro-8-methylnona-2,7-diene-5,5-diyldisulfonyl)dibenzene (11a)}

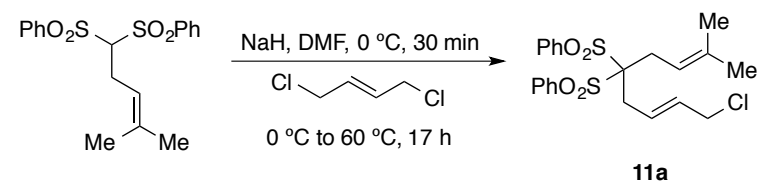

A flame-dried $25 \mathrm{~mL}$ round-bottomed flask with stir bar was charged with (4-methylpent-3ene-1,1-diyldisulfonyl)dibenzene ${ }^{v}(364 \mathrm{mg}, 1 \mathrm{mmol}, 1$ eq.) and placed under argon. $5 \mathrm{~mL}$ of dry DMF was added via syringe and the solution was cooled to 0 degrees with an ice/water bath. Sodium hydride ( $60 \mathrm{wt} \%$ dispersion in mineral oil, $43 \mathrm{mg}, 1.1 \mathrm{mmol}, 1.1 \mathrm{eq}$ ) was added in one portion and the reaction was allowed to stir at 0 degrees for 30 minutes. trans-1,4-dichloro-2-butene $(0.211 \mathrm{~mL}, 2 \mathrm{mmol}, 2 \mathrm{eq}$.) was added rapidly via syringe at 0 degrees. The reaction was taken out of the ice bath and placed in a 60 degree oil bath where it was allowed to stir for 17 hours. After 17 hours, the reaction was cooled to room temperature and $3 \mathrm{~mL}$ of saturated aqueous ammonium chloride was added. The reaction was diluted with ether $(5 \mathrm{~mL})$, the layers were shaken, and separated. The aqueous phase was extracted once with ether $(5 \mathrm{~mL})$. The combined organics were washed with water ( $3 \times 5 \mathrm{~mL}$ ), dried over $\mathrm{MgSO}_{4}$, 
filtered, and concentrated. Purification by silica gel chromatography (5:1 hexanes:EtOAc) yielded (E)-(1chloro-8-methylnona-2,7-diene-5,5-diyldisulfonyl)dibenzene 11a as a white solid (231 $\mathrm{mg}, 0.51 \mathrm{mmol}$, $51 \%$ yield). $\left[\mathrm{R}_{\mathrm{f}}=0.13\right.$ (3:1 hexanes:EtOAc)]; IR (thin film): 3065, 2913, 1583, 1478, 1446, 1328, 1308, $1140,1076,1024,999,968,909,859,756,723,685,648,562,517 \mathrm{~cm}^{-1} ;{ }^{1} \mathrm{H}-\mathrm{NMR}\left(400 \mathrm{MHz} ; \mathrm{CDCl}_{3}\right): \delta$ $8.04(\mathrm{~d}, J=7.6 \mathrm{~Hz}, 4 \mathrm{H}), 7.70(\mathrm{t}, J=7.4 \mathrm{~Hz}, 2 \mathrm{H}), 7.58(\mathrm{t}, J=7.8 \mathrm{~Hz}, 4 \mathrm{H}), 5.94(\mathrm{dt}, J=14.8,7.1 \mathrm{~Hz}, 1 \mathrm{H}), 5.69$ $(\mathrm{dt}, J=14.8,7.0 \mathrm{~Hz}, 1 \mathrm{H}), 5.29(\mathrm{t}, J=4.7 \mathrm{~Hz}, 1 \mathrm{H}), 4.03(\mathrm{~d}, J=7.1 \mathrm{~Hz}, 2 \mathrm{H}), 3.02(\mathrm{~d}, J=7.0 \mathrm{~Hz}, 2 \mathrm{H}), 2.91(\mathrm{~d}, J=$ $6.2 \mathrm{~Hz}, 2 \mathrm{H}), 1.71(\mathrm{~s}, 3 \mathrm{H}), 1.52(\mathrm{~s}, 3 \mathrm{H}) ;{ }^{13} \mathrm{C}-\mathrm{NMR}\left(101 \mathrm{MHz}, \mathrm{CDCl}_{3}\right): \delta$ 137.14, 136.88, 134.84, 131.72, 131.42, 128.76, 127.13, 115.09, 90.56, 44.76, 31.86, 28.31, 26.31, 18.41; HR-MS (m/z): [M + $\left.\mathrm{Na}^{+}\right]$calcd for $\mathrm{C}_{22} \mathrm{H}_{25} \mathrm{ClNaO}_{4} \mathrm{~S}_{2}$ : 475.0781; found: 475.0781 .

\section{((1E,6E)-8-chloro-1-phenylocta-1,6-diene-4,4-diyldisulfonyl)dibenzene (11b)}

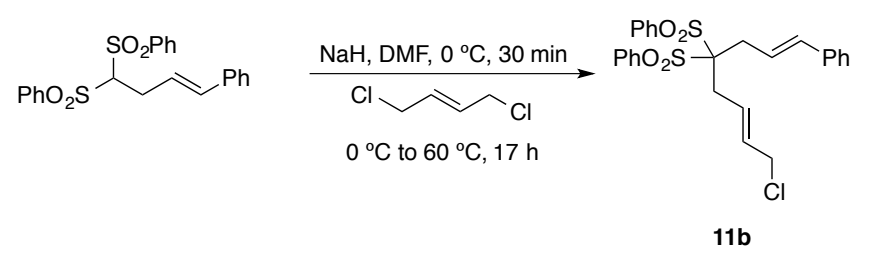

A flame-dried $25 \mathrm{~mL}$ round-bottomed flask with stir bar was charged with $(E)$-(4-phenylbut-3ene-1,1-diyldisulfonyl)dibenzene ${ }^{\text {vi }}$ (500 mg, $1.2 \mathrm{mmol}, 1$ eq.) and placed under argon. $6 \mathrm{~mL}$ of dry DMF was added via syringe and the solution was cooled to 0 degrees with an ice/water bath. Sodium hydride ( $60 \mathrm{wt} \%$ dispersion in mineral oil, $53 \mathrm{mg}, 1.3 \mathrm{mmol}, 1.1 \mathrm{eq}$.) was added in one portion and the reaction was allowed to stir at 0 degrees for 30 minutes. trans-1,4-dichloro-2-butene $(0.25 \mathrm{~mL}, 2.4 \mathrm{mmol}, 2 \mathrm{eq}$.) was added rapidly via syringe at 0 degrees. The reaction was taken out of the ice bath and placed in a 60 degree oil bath where it was allowed to stir for 17 hours. After 17 hours, the reaction was cooled to room temperature and $3 \mathrm{~mL}$ of saturated aqueous ammonium chloride was added. The reaction was diluted with ether $(5 \mathrm{~mL})$, the layers were shaken, and separated. The aqueous phase was extracted once with ether ( $5 \mathrm{~mL}$ ). The combined organics were washed with water ( $3 \mathrm{x} 5 \mathrm{~mL}$ ), dried over $\mathrm{MgSO}_{4}$, filtered, and concentrated. Purification by silica gel chromatography (3:1 hexanes:EtOAc) yielded $((1 E, 6 E)$-8-chloro-1-phenylocta-1,6-diene-4,4-diyldisulfonyl)dibenzene $\mathbf{1 1 b}$ as a white solid (248 $\mathrm{mg}$, $0.49 \mathrm{mmol}, 41 \%$ yield). [ $\mathrm{R}_{\mathrm{f}}=0.2$ (3:1 hexanes:EtOAc)]; IR (thin film): 3062, 3026, 2954, 2361, 2342, 1598, 1583, 1496, 1478, 1447, 1329, 1309, 1255, 1141, 1076, 1024, 999, 966, 910, 753, 724, 686, 649, 615, 593, 574, $566 \mathrm{~cm}^{-1} ;{ }^{1} \mathrm{H}-\mathrm{NMR}\left(400 \mathrm{MHz} ; \mathrm{CDCl}_{3}\right): \delta 8.07(\mathrm{~d}, J=7.4 \mathrm{~Hz}, 4 \mathrm{H}), 7.71(\mathrm{t}, J=7.4 \mathrm{~Hz}, 2 \mathrm{H}), 7.58$ $(\mathrm{t}, J=7.8 \mathrm{~Hz}, 4 \mathrm{H}), 7.32-7.27(\mathrm{~m}, 5 \mathrm{H}), 6.47(\mathrm{~d}, J=15.7 \mathrm{~Hz}, 1 \mathrm{H}), 6.27(\mathrm{dt}, J=15.7,7.0 \mathrm{~Hz}, 1 \mathrm{H}), 6.03(\mathrm{dt}, J=$ 14.8, 7.2 Hz, 1H), $5.71(\mathrm{dt}, J=14.8,7.3 \mathrm{~Hz}, 1 \mathrm{H}), 4.03(\mathrm{~d}, J=7.0 \mathrm{~Hz}, 2 \mathrm{H}), 3.16(\mathrm{~d}, J=6.9 \mathrm{~Hz}, 2 \mathrm{H}), 3.06$ (d, $J=$ $6.7 \mathrm{~Hz}, 2 \mathrm{H}) ;{ }^{13} \mathrm{C}-\mathrm{NMR}\left(101 \mathrm{MHz}, \mathrm{CDCl}_{3}\right): \delta 136.90,136.64,136.08,134.99,131.86,131.82,128.92$, 128.86, 128.16, 126.94, 126.64, 121.07, 90.38, 44.66, 33.79, 32.90; HR-MS (m/z): [M+ $\left.\mathrm{Na}^{+}\right]$calcd for $\mathrm{C}_{27} \mathrm{H}_{34} \mathrm{NaO}_{5} \mathrm{~S}_{2}$ : 523.0781; found: 523.0781 . 


\section{$((2 E, 7 E)-1$-chloro-8,12-dimethyltrideca-2,7,11-triene-5,5-diyldisulfonyl)dibenzene (13)}

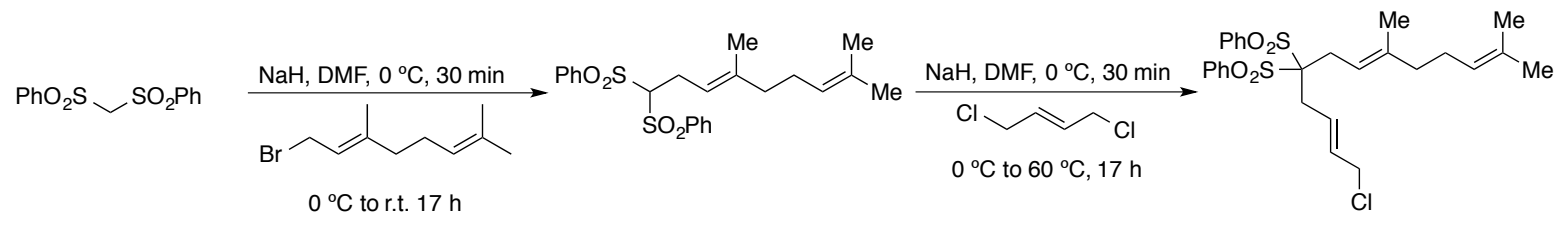

S12

13

A flame-dried $50 \mathrm{~mL}$ round-bottomed flask with stir bar was charged with bis(phenylsulfonyl)methane (889 mg, $3 \mathrm{mmol}, 1 \mathrm{eq}$.$) and placed under argon. 5 \mathrm{~mL}$ of dry DMF was added via syringe and the solution was cooled to 0 degrees with an ice/water bath. Sodium hydride (60 $\mathrm{wt} \%$ dispersion in mineral oil, $132 \mathrm{mg}, 1.1 \mathrm{mmol}, 1.1 \mathrm{eq}$.$) was added in one portion and the reaction was$ allowed to stir at 0 degrees for 30 minutes. Geranyl bromide (0.628 mL, $3.15 \mathrm{mmol}, 1.05$ eq.) was added rapidly via syringe at 0 degrees. The reaction was taken out of the ice bath and warmed to room temperature where it was allowed to stir for 17 hours. After 17 hours, the reaction was cooled to room temperature and $15 \mathrm{~mL}$ of saturated aqueous ammonium chloride was added. The reaction was diluted with ether $(15 \mathrm{~mL})$, the layers were shaken, and separated. The aqueous phase was extracted once with ether (15 mL). The combined organics were washed with water (3x $15 \mathrm{~mL})$, dried over $\mathrm{MgSO}_{4}$, filtered, and concentrated. Purification by silica gel chromatography (5:1 hexanes:EtOAc) yielded $(E)-(4,8-$ dimethylnona-3,7-diene-1,1-diyldisulfonyl)dibenzene $\mathbf{S 1 2}$ as a white solid (1.03 g , 2.38 mmol, 79\% yield). $\left[\mathrm{R}_{\mathrm{f}}=0.29\right.$ (3:1 hexanes:EtOAc)]; IR (thin film): 3065, 2914, 1584, 1478, 1447, 1376, 1328, 1310, $1147,1078,1024,998,912,727,685,647,610,551,519 \mathrm{~cm}^{-1} ;{ }^{1} \mathrm{H}-\mathrm{NMR}\left(400 \mathrm{MHz} ; \mathrm{CDCl}_{3}\right): \delta 7.95(\mathrm{~d}, J=$ $7.4 \mathrm{~Hz}, 4 \mathrm{H}), 7.68(\mathrm{t}, J=7.5 \mathrm{~Hz}, 2 \mathrm{H}), 7.56(\mathrm{t}, J=7.8 \mathrm{~Hz}, 4 \mathrm{H}), 5.03(\mathrm{t}, J=6.8 \mathrm{~Hz}, 2 \mathrm{H}), 4.43(\mathrm{t}, J=6.3 \mathrm{~Hz}, 1 \mathrm{H})$, $2.87(\mathrm{t}, J=6.3 \mathrm{~Hz}, 2 \mathrm{H}), 1.95(\mathrm{~m}, J=7.0 \mathrm{~Hz}, 2 \mathrm{H}), 1.87(\mathrm{t}, J=7.5 \mathrm{~Hz}, 2 \mathrm{H}), 1.67(\mathrm{~s}, 3 \mathrm{H}), 1.58(\mathrm{~s}, 3 \mathrm{H}), 1.45(\mathrm{~s}$, 3H); ${ }^{13} \mathrm{C}-\mathrm{NMR}\left(101 \mathrm{MHz}, \mathrm{CDCl}_{3}\right): \delta$ 139.80, 138.30, 134.79, 131.97, 129.81, 129.30, 124.00, 118.18, 84.39, 39.66, 26.47, 25.97, 24.84, 17.99, 16.37; HR-MS (m/z): [M + $\left.\mathrm{Na}^{+}\right]$calcd for $\mathrm{C}_{23} \mathrm{H}_{28} \mathrm{NaO}_{4} \mathrm{~S}_{2}$ : 455.1327; found: 455.1327.

A flame-dried $25 \mathrm{~mL}$ round-bottomed flask with stir bar was charged with $\mathbf{S 1 2}$ (649 mg, 1.5 mmol, 1 eq.) and placed under argon. $7.5 \mathrm{~mL}$ of dry DMF was added via syringe and the solution was cooled to 0 degrees with an ice/water bath. Sodium hydride (60 wt\% dispersion in mineral oil, $67 \mathrm{mg}$, $1.1 \mathrm{mmol}, 1.1 \mathrm{eq.}$ ) was added in one portion and the reaction was allowed to stir at 0 degrees for 30 minutes. trans-1,4-dichloro-2-butene $(0.318 \mathrm{~mL}, 3 \mathrm{mmol}, 2$ eq.) was added rapidly via syringe at 0 degrees. The reaction was taken out of the ice bath and placed in a 60 degree oil bath where it was allowed to stir for 17 hours. After 17 hours, the reaction was cooled to room temperature and $5 \mathrm{~mL}$ of saturated aqueous ammonium chloride was added. The reaction was diluted with ether (10 $\mathrm{mL})$, the layers were shaken, and separated. The aqueous phase was extracted once with ether (10 mL). The combined organics were washed with water (3x $10 \mathrm{~mL})$, dried over $\mathrm{MgSO}_{4}$, filtered, and concentrated. Purification by silica gel chromatography $(5: 1$ hexanes:EtOAc) yielded $((2 E, 7 E)-1$-chloro-8,12dimethyltrideca-2,7,11-triene-5,5-diyldisulfonyl)dibenzene 13 as a light yellow oil (357 mg, $0.69 \mathrm{mmol}$, 
$46 \%$ yield). [ $\mathrm{R}_{\mathrm{f}}=0.36$ (3:1 hexanes:EtOAc)]; IR (thin film): 2915, 1583, 1478, 1446, 1376, 1328, 1309, $1254,1141,1076,1024,999,968,911,755,724,685,562,529 \mathrm{~cm}^{-1} ;{ }^{1} \mathrm{H}-\mathrm{NMR}\left(400 \mathrm{MHz} ; \mathrm{CDCl}_{3}\right): \delta 8.06$ (d, $J=7.4 \mathrm{~Hz}, 4 \mathrm{H}), 7.70(\mathrm{t}, J=7.4 \mathrm{~Hz}, 2 \mathrm{H}), 7.57(\mathrm{t}, J=7.8 \mathrm{~Hz}, 4 \mathrm{H}), 5.96-5.92(\mathrm{~m}, 1 \mathrm{H}), 5.72-5.68(\mathrm{~m}, 1 \mathrm{H})$, $5.34-5.31(\mathrm{~m}, 1 \mathrm{H}), 5.07(\mathrm{t}, J=5.7 \mathrm{~Hz}, 1 \mathrm{H}), 4.03(\mathrm{~d}, J=7.0 \mathrm{~Hz}, 2 \mathrm{H}), 3.04(\mathrm{~d}, J=6.7 \mathrm{~Hz}, 2 \mathrm{H}), 2.92(\mathrm{~d}, J=6.2$ $\mathrm{Hz}, 2 \mathrm{H}), 2.08-1.98(\mathrm{~m}, 4 \mathrm{H}), 1.69(\mathrm{~s}, 3 \mathrm{H}), 1.61(\mathrm{~s}, 3 \mathrm{H}), 1.53(\mathrm{~s}, 3 \mathrm{H}) ;{ }^{13} \mathrm{C}-\mathrm{NMR}\left(101 \mathrm{MHz}, \mathrm{CDCl}_{3}\right): \delta 140.53$, 136.86, 134.84, 131.72, 131.44, 128.77, 128.57, 127.12, 124.08, 114.97, 90.62, 44.77, 40.01, 31.67, 28.09, 26.44, 26.01, 18.06, 16.83; HR-MS (m/z): $\left[\mathrm{M}+\mathrm{Na}^{+}\right]$calcd for $\mathrm{C}_{27} \mathrm{H}_{33} \mathrm{ClNaO}_{4} \mathrm{~S}_{2}$ : 543.1407; found: 543.1406 .

\section{$((2 E, 7 Z)-1$-chloro-8,12-dimethyltrideca-2,7,11-triene-5,5-diyldisulfonyl)dibenzene (15)}

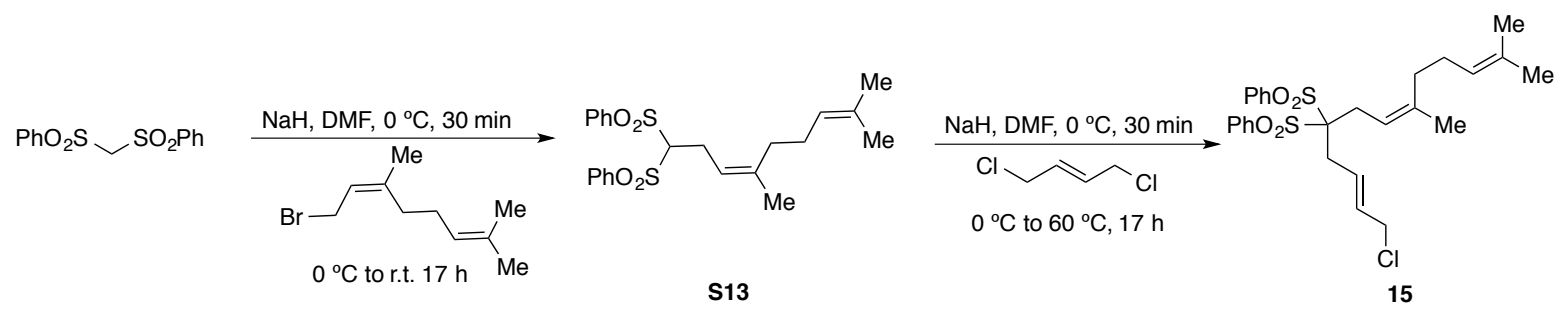

A flame-dried $50 \mathrm{~mL}$ round-bottomed flask with stir bar was charged with bis(phenylsulfonyl)methane (889 mg, $3 \mathrm{mmol}, 1$ eq.) and placed under argon. $5 \mathrm{~mL}$ of dry DMF was added via syringe and the solution was cooled to 0 degrees with an ice/water bath. Sodium hydride (60 wt $\%$ dispersion in mineral oil, $132 \mathrm{mg}, 1.1 \mathrm{mmol}, 1.1 \mathrm{eq}$.) was added in one portion and the reaction was allowed to stir at 0 degrees for 30 minutes. Neryl bromide (684 mg, $3.15 \mathrm{mmol}, 1.05$ eq.) was added rapidly via syringe at 0 degrees. The reaction was taken out of the ice bath and warmed to room temperature where it was allowed to stir for 17 hours. After 17 hours, the reaction was cooled to room temperature and $15 \mathrm{~mL}$ of saturated aqueous ammonium chloride was added. The reaction was diluted with ether $(15 \mathrm{~mL})$, the layers were shaken, and separated. The aqueous phase was extracted once with ether $(15 \mathrm{~mL})$. The combined organics were washed with water $(3 \times 15 \mathrm{~mL})$, dried over $\mathrm{MgSO}_{4}$, filtered, and concentrated. Purification by silica gel chromatography (5:1 hexanes:EtOAc) yielded $(Z)-(4,8-$ dimethylnona-3,7-diene-1,1-diyldisulfonyl)dibenzene $\mathbf{S 1 3}$ as a white solid (931 $\mathrm{mg}, 2.15 \mathrm{mmol}, 72 \%$ yield). [ $R_{\mathrm{f}}=0.29$ (3:1 hexanes:EtOAc)]; IR (thin film): 2925, 1583, 1446, 1376, 1322, 1311, 1145, 1078, 1023, 998, 909, 832, 751, 727, 685, 647, 622, 610, 570, 554, $516 \mathrm{~cm}^{-1} ;{ }^{1} \mathrm{H}-\mathrm{NMR}\left(400 \mathrm{MHz} ; \mathrm{CDCl}_{3}\right): \delta 7.94$ $(\mathrm{d}, J=8.1 \mathrm{~Hz}, 4 \mathrm{H}), 7.67(\mathrm{t}, J=7.4 \mathrm{~Hz}, 2 \mathrm{H}), 7.55(\mathrm{t}, J=7.7 \mathrm{~Hz}, 4 \mathrm{H}), 5.02(\mathrm{~m}, 2 \mathrm{H}), 4.43(\mathrm{t}, J=6.1 \mathrm{~Hz}, 1 \mathrm{H}), 2.87$ $(\mathrm{t}, J=6.4 \mathrm{~Hz}, 2 \mathrm{H}), 1.99-1.90(\mathrm{~m}, 2 \mathrm{H}), 1.90-1.81(\mathrm{~m}, 2 \mathrm{H}), 1.66(\mathrm{~s}, 3 \mathrm{H}), 1.57(\mathrm{~s}, 6 \mathrm{H}) ;{ }^{13} \mathrm{C}-\mathrm{NMR}(101 \mathrm{MHz}$, $\left.\mathrm{CDCl}_{3}\right): \delta$ 139.95, 138.34, 134.78, 132.37, 129.81, 129.29, 123.86, 118.93, 84.44, 32.00, 26.23, 26.00, 24.62, 23.56, 17.96; HR-MS (m/z): [M + $\left.\mathrm{H}^{+}\right]$calcd for $\mathrm{C}_{23} \mathrm{H}_{28} \mathrm{NaO}_{4} \mathrm{~S}_{2}: 455.1327$; found: 455.1327 .

A flame-dried $25 \mathrm{~mL}$ round-bottomed flask with stir bar was charged with $\mathbf{S 1 3}$ (649 mg, 1.5 mmol, 1 eq.) and placed under argon. $7.5 \mathrm{~mL}$ of dry DMF was added via syringe and the solution was cooled to 0 degrees with an ice/water bath. Sodium hydride (60 wt\% dispersion in mineral oil, $67 \mathrm{mg}$, 
$1.1 \mathrm{mmol}, 1.1 \mathrm{eq}$.) was added in one portion and the reaction was allowed to stir at 0 degrees for 30 minutes. trans-1,4-dichloro-2-butene $(0.318 \mathrm{~mL}, 3 \mathrm{mmol}, 2$ eq.) was added rapidly via syringe at 0 degrees. The reaction was taken out of the ice bath and placed in a 60 degree oil bath where it was allowed to stir for 17 hours. After 17 hours, the reaction was cooled to room temperature and $5 \mathrm{~mL}$ of saturated aqueous ammonium chloride was added. The reaction was diluted with ether $(10 \mathrm{~mL})$, the layers were shaken, and separated. The aqueous phase was extracted once with ether $(10 \mathrm{~mL})$. The combined organics were washed with water (3x $10 \mathrm{~mL}$ ), dried over $\mathrm{MgSO}_{4}$, filtered, and concentrated. Purification by silica gel chromatography (5:1 hexanes:EtOAc) yielded ((2E,7Z)-1-chloro-8,12dimethyltrideca-2,7,11-triene-5,5-diyldisulfonyl)dibenzene 15 as a light yellow oil (437 $\mathrm{mg}, 0.84 \mathrm{mmol}$, $56 \%$ yield). $\left[\mathrm{R}_{\mathrm{f}}=0.36\right.$ (3:1 hexanes: EtOAc)]; IR (thin film): 2915, 1583, 1478, 1447, 1375, 1329, 1309, 1253, 1140, 1076, 999, 968, 908, 756, 724, 685, 648, 562, $518 \mathrm{~cm}^{-1} ;{ }^{1} \mathrm{H}-\mathrm{NMR}\left(400 \mathrm{MHz} ; \mathrm{CDCl}_{3}\right): \delta 8.06$ $(\mathrm{d}, J=7.4 \mathrm{~Hz}, 4 \mathrm{H}), 7.70(\mathrm{t}, J=7.4 \mathrm{~Hz}, 2 \mathrm{H}), 7.58(\mathrm{t}, J=7.7 \mathrm{~Hz}, 4 \mathrm{H}), 5.96(\mathrm{dt}, J=14.8,7.2 \mathrm{~Hz}, 1 \mathrm{H}), 5.70(\mathrm{dt}, J=$ 14.8, 7.2 Hz, 1H), $5.32(\mathrm{t}, J=6.1 \mathrm{~Hz}, 1 \mathrm{H}), 5.03(\mathrm{t}, J=7.0 \mathrm{~Hz}, 1 \mathrm{H}), 4.03(\mathrm{~d}, J=7.0 \mathrm{~Hz}, 2 \mathrm{H}), 3.03(\mathrm{~d}, J=6.8 \mathrm{~Hz}$, 2H), $2.94(\mathrm{~d}, J=6.1 \mathrm{~Hz}, 2 \mathrm{H}), 2.04(\mathrm{~m}, 2 \mathrm{H}), 1.93(\mathrm{t}, J=7.3 \mathrm{~Hz}, 2 \mathrm{H}), 1.72(\mathrm{~s}, 3 \mathrm{H}), 1.67(\mathrm{~s}, 3 \mathrm{H}), 1.59(\mathrm{~s}, 3 \mathrm{H})$; ${ }^{13} \mathrm{C}-\mathrm{NMR}\left(101 \mathrm{MHz}, \mathrm{CDCl}_{3}\right): \delta$ 140.77, 136.98, 134.86, 131.76, 131.42, 128.78, 128.59, 127.25, 123.88, 115.66, 90.46, 44.77, 32.47, 32.11, 28.28, 26.18, 26.02, 24.10, 17.97; HR-MS (m/z): [M + $\left.\mathrm{Na}^{+}\right]$calcd for $\mathrm{C}_{27} \mathrm{H}_{33} \mathrm{ClNaO}_{4} \mathrm{~S}_{2}$ : 543.1407; found: 543.1406 .

\section{$N$-((E)-4-chlorobut-2-en-1-yl)-2-methyl- $N$-((E)-4-phenylbut-3-en-1-yl)propane-2-sulfonamide} (17)

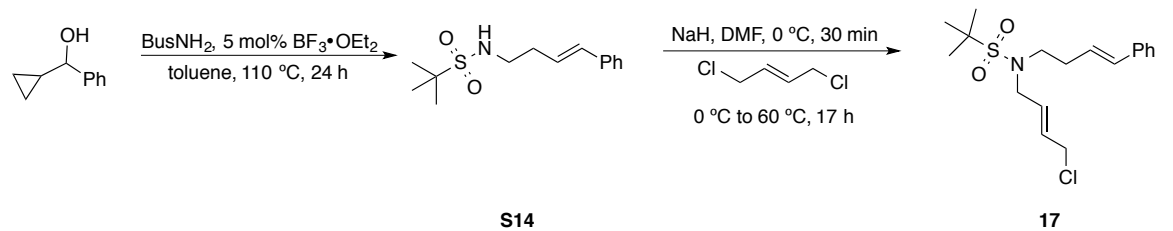

tert-butylsulfonamide ( $686 \mathrm{mg}, 5 \mathrm{mmol}, 2$ eq.) was added to a flame-dried $50 \mathrm{~mL}$ round bottom flask with stir bar. $17 \mathrm{~mL}$ of toluene was added via syringe followed by cyclopropyl(phenyl)methanolvii (371 mg, $2.5 \mathrm{mmol}, 1$ eq.). $\mathrm{BF}_{3} \bullet \mathrm{OEt}_{2}(0.015 \mathrm{~mL}, 0.12 \mathrm{mmol}, 0.05 \mathrm{eq}$.) was added via syringe and the reaction was heated to 110 degrees in a pre-heated oil bath for 24 hours. After cooling to room temperature, the reaction mixture was subjected to silica gel chromatography (3:1 hexanes:EtOAc) to yield (E)-2-methyl- $N$-(4-phenylbut-3-en-1-yl)propane-2-sulfonamide $\mathbf{S 1 4}$ as a white solid (130 mg, 0.49 mmol, 20\% yield). [ $\mathrm{R}_{\mathrm{f}}=0.29$ (3:1 hexanes:EtOAc)]; IR (thin film): 3290, 3025, 2976, 2931, 1494, 1478, $1448,1395,1365,1300,1207,1123,1079,1021,965,873,828,741,693,661,537,512 \mathrm{~cm}^{-1}$; ${ }^{1} \mathrm{H}-\mathrm{NMR}$ (400 MHz; $\left.\mathrm{CDCl}_{3}\right): \delta 7.36-7.21(\mathrm{~m}, 5 \mathrm{H}), 6.50(\mathrm{~d}, J=15.6 \mathrm{~Hz}, 1 \mathrm{H}), 6.14(\mathrm{dt}, J=15.6,7.5 \mathrm{~Hz}, 1 \mathrm{H}), 4.17(\mathrm{br} \mathrm{s}$, $1 \mathrm{H}), 3.32(\mathrm{q}, J=6.5 \mathrm{~Hz}, 2 \mathrm{H}), 2.48(\mathrm{q}, J=6.8 \mathrm{~Hz}, 2 \mathrm{H}), 1.39(\mathrm{~s}, 9 \mathrm{H}) ;{ }^{13} \mathrm{C}-\mathrm{NMR}\left(101 \mathrm{MHz}, \mathrm{CDCl}_{3}\right): \delta 137.14$, 133.39, 128.81, 127.70, 126.38, 126.04, 60.14, 44.48, 35.00, 24.58; HR-MS (m/z): [M + $\left.\mathrm{Na}^{+}\right]$calcd for $\mathrm{C}_{14} \mathrm{H}_{21} \mathrm{NNaO}_{2} \mathrm{~S}: 290.1191$; found: 290.1191. 
A flame-dried $25 \mathrm{~mL}$ round-bottomed flask with stir bar was charged with $\mathbf{S 1 4}$ (107 mg, 0.4 mmol, 1 eq.) and placed under argon. $2 \mathrm{~mL}$ of dry DMF was added via syringe and the solution was cooled to 0 degrees with an ice/water bath. Sodium hydride (60 wt\% dispersion in mineral oil, $18 \mathrm{mg}$, $0.44 \mathrm{mmol}, 1.1$ eq.) was added in one portion and the reaction was allowed to stir at 0 degrees for 30 minutes. trans-1,4-dichloro-2-butene $(0.085 \mathrm{~mL}, 0.8 \mathrm{mmol}, 2 \mathrm{eq}$.) was added rapidly via syringe at 0 degrees. The reaction was taken out of the ice bath and placed in a 60 degree oil bath where it was allowed to stir for 17 hours. After 17 hours, the reaction was cooled to room temperature and $2 \mathrm{~mL}$ of saturated aqueous ammonium chloride was added. The reaction was diluted with ether (5 mL), the layers were shaken, and separated. The aqueous phase was extracted once with ether (5 mL). The combined organics were washed with water $(3 \times 5 \mathrm{~mL})$, dried over $\mathrm{MgSO}_{4}$, filtered, and concentrated. Purification by silica gel chromatography (5:1 hexanes:EtOAc) $N$ - ((E)-4-chlorobut-2-en-1-yl)-2-methyl$\mathrm{N}$-((E)-4-phenylbut-3-en-1-yl)propane-2-sulfonamide 17 as a light yellow oil (74 $\mathrm{mg}, 0.21 \mathrm{mmol}, 53 \%$ yield). $\left[\mathrm{R}_{\mathrm{f}}=0.5\right.$ (3:1 hexanes:EtOAc)]; IR (thin film): 3025, 2974, 2931, 1479, 1448, 1394, 1363, 1313, $1204,1124,1072,1026,967,925,810,742,693,643,550,512 \mathrm{~cm}^{-1} ;{ }^{1} \mathrm{H}-\mathrm{NMR}\left(400 \mathrm{MHz} ; \mathrm{CDCl}_{3}\right): \delta 7.35-$ $7.28(\mathrm{~m}, 4 \mathrm{H}), 7.21(\mathrm{t}, J=7.0 \mathrm{~Hz}, 1 \mathrm{H}), 6.45(\mathrm{~d}, J=15.6 \mathrm{~Hz}, 1 \mathrm{H}), 6.13(\mathrm{dt}, J=15.6,7.5 \mathrm{~Hz}, 1 \mathrm{H}), 5.91-5.80(\mathrm{~m}$, 2H), $4.08(\mathrm{~d}, J=5.5 \mathrm{~Hz}, 2 \mathrm{H}), 3.96(\mathrm{~d}, J=5.0 \mathrm{~Hz}, 2 \mathrm{H}), 3.37(\mathrm{t}, J=7.6 \mathrm{~Hz}, 2 \mathrm{H}), 2.51(\mathrm{q}, J=7.5 \mathrm{~Hz}, 2 \mathrm{H}), 1.39(\mathrm{~s}$, 9H); ${ }^{13} \mathrm{C}-\mathrm{NMR}\left(101 \mathrm{MHz}, \mathrm{CDCl}_{3}\right): \delta$ 137.34, 132.59, 130.91, 130.33, 128.79, 127.55, 126.29, 126.28, 61.82, 49.63, 48.05, 44.20, 32.61, 24.95; HR-MS (m/z): [M + $\left.\mathrm{Na}^{+}\right]$calcd for $\mathrm{C}_{18} \mathrm{H}_{26} \mathrm{ClNNaO}_{2} \mathrm{~S}: 378.1271$; found: 378.1270

\section{Asymmetric Interrupted Metallo-ene reaction}

\section{General Procedure A}

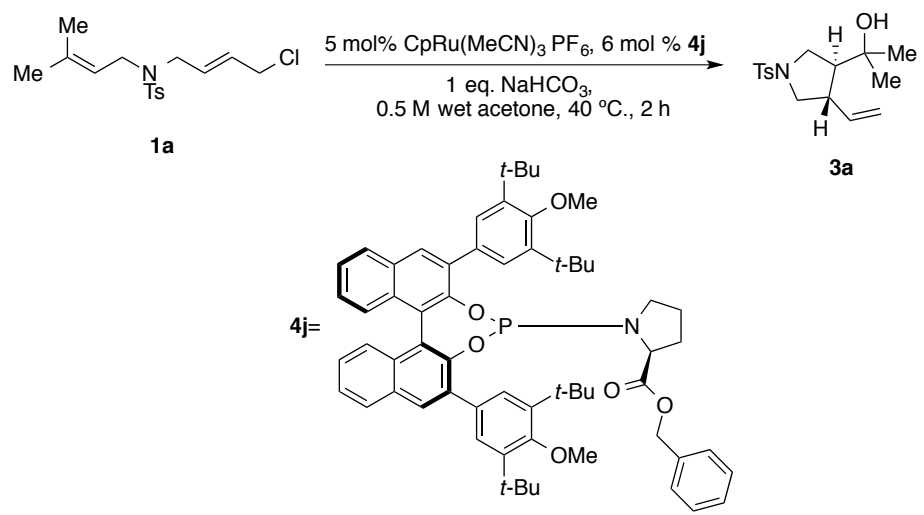

A microwave vial with stir bar was charged with allyl chloride 1a (33 mg, $0.1 \mathrm{mmol}, 1$ eq.) and $8.4 \mathrm{mg}$ of sodium bicarbonate $(0.1 \mathrm{mmol}, 1$ eq.). A separate vial with stir bar was charged with $\mathrm{CpRu}(\mathrm{MeCN})_{3} \mathrm{PF}_{6}$ (2.2 mg, $0.005 \mathrm{mmol}, 0.05$ eq.), 4j (5.7 mg, $0.006 \mathrm{mmol}, 0.06$ eq.), and $0.2 \mathrm{~mL}$ of acetone. This solution was allowed to stir at room temperature for 5 minutes before being added to the 
substrate vial where it was heated to 40 degrees for 5 hours. After 5 hours, the reaction was cooled to room temperature, diluted with ether, filtered through a plug celite, and concentrated in vacuo. The crude product was purified via silica gel chromatography $(3: 1$ hexanes:EtOAc) to yield $2-((3 S, 4 S)-1$ tosyl-4-vinylpyrrolidin-3-yl)propan-2-ol 3a as a clear liquid (24 mg, $0.078 \mathrm{mmol}, 78 \%$ yield). [ $\mathrm{R}_{\mathrm{f}}=0.2$ (3:1 hexanes:EtOAc)]; $[\alpha]_{\mathrm{D}^{25}}=-23.46^{\circ}\left(1.0, \mathrm{CHCl}_{3}\right)$; IR (thin film): 3395, 2934, 1619, 1576, 1449, 1321, 1146, 1093, 1016, 908, 804, 699, 655, 587, $542 \mathrm{~cm}^{-1} ;{ }^{1} \mathrm{H}-\mathrm{NMR}\left(400 \mathrm{MHz} ; \mathrm{CDCl}_{3}\right): \delta 7.70$ (d, $J=8.3 \mathrm{~Hz}$, 2H), $7.33(\mathrm{~d}, J=8.5 \mathrm{~Hz}, 2 \mathrm{H}), 5.64(\mathrm{ddd}, J=17.5,10.1,8.8 \mathrm{~Hz}, 1 \mathrm{H}), 5.08(\mathrm{~d}, J=17.5 \mathrm{~Hz}, 1 \mathrm{H}), 5.01(\mathrm{~d}, J=10.1$ $\mathrm{Hz}, 1 \mathrm{H}$ ), 3.44 (dd, $J=9.7,7.8 \mathrm{~Hz}, 1 \mathrm{H}$ ), 3.34 (dd, $J=10.0,8.6 \mathrm{~Hz}, 1 \mathrm{H}$ ), 3.14 (dd, $J=10.0,8.7 \mathrm{~Hz}, 1 \mathrm{H}$ ), 2.89 (t, $J=9.2 \mathrm{~Hz}, 1 \mathrm{H}$ ), 2.71 (quintet, $J=8.5 \mathrm{~Hz}, 1 \mathrm{H}), 2.44(\mathrm{~s}, 3 \mathrm{H}), 2.00(\mathrm{q}, J=8.7 \mathrm{~Hz}, 1 \mathrm{H}), 1.14(\mathrm{~s}, 6 \mathrm{H}) ;{ }^{13} \mathrm{C}-\mathrm{NMR}$ $\left(101 \mathrm{MHz}, \mathrm{CDCl}_{3}\right): \delta 143.83,139.52,133.18,129.91,127.96,116.95,71.82,54.47,53.93,49.75,44.54$, 28.30, 28.20, 21.80; [Chiracel ${ }^{\circledR}$ AD column, eluting with 60:40 heptane $/ \mathrm{IPA}, 0.8 \mathrm{~mL} / \mathrm{min}, 254 \mathrm{~nm}$; $\mathrm{t}_{\mathrm{r}}=$ 17.1 and $28.5 \mathrm{~min}, 94: 6$ e.r.]; HR-MS (m/z): $\left[\mathrm{M}+\mathrm{Na}^{+}\right]$calcd for $\mathrm{C}_{16} \mathrm{H}_{23} \mathrm{NNaO}_{3} \mathrm{~S}$ : 332.1297; found: 332.1296 .

\section{(S)-phenyl((3S,4S)-1-tosyl-4-vinylpyrrolidin-3-yl)methanol (3b)}

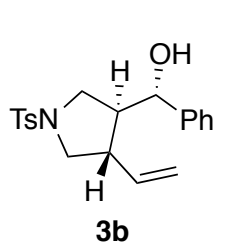

General procedure A was followed with allylic chloride $\mathbf{1 b}(75 \mathrm{mg}, 0.2 \mathrm{mmol}, 1$ eq.), $\mathrm{NaHCO}_{3}$ (16.8 mg, $0.2 \mathrm{mmol}, 1$ eq.), $\mathrm{CpRu}(\mathrm{MeCN})_{3} \mathrm{PF}_{6}$ (4.4 mg, $0.01 \mathrm{mmol}, 0.05$ eq.), 4j (16.4 mg, $0.012 \mathrm{mmol}, 0.06 \mathrm{eq}$.$) , and acetone (0.4 \mathrm{~mL})$. Purification by silica gel chromatography (4:1 hexanes:EtOAc) yielded $\mathbf{3 b}$ as a colorless liquid $(40 \mathrm{mg}, 0.11$ mmol, $55 \%$ yield). $\left[\mathrm{R}_{\mathrm{f}}=0.2\left(3: 1\right.\right.$ hexanes:EtOAc)]; $[\alpha]_{\mathrm{D}}{ }^{25}=-28.52^{\circ}\left(1.0, \mathrm{CHCl}_{3}\right) ; \mathrm{IR}$ (thin film): 3450, 2879, 1620, 1576, 1473, 1432, 1380, 1320, 1146, 1075, 1015, 906, 804, 750, 723, 695, 655, 583, $541 \mathrm{~cm}^{-1} ;{ }^{1} \mathrm{H}-\mathrm{NMR}\left(400 \mathrm{MHz} ; \mathrm{CDCl}_{3}\right): \delta 7.69(\mathrm{~d}, J=8.2 \mathrm{~Hz}, 2 \mathrm{H}), 7.33-7.21(\mathrm{~m}, 7 \mathrm{H}), 5.39$ (ddd, $J=$ 17.0, 10.2, $8.3 \mathrm{~Hz}, 1 \mathrm{H}$ ), 4.88 (app. t, $J=12.7 \mathrm{~Hz}, 2 \mathrm{H}$ ), 4.56 (d, $J=5.4 \mathrm{~Hz}, 1 \mathrm{H}$ ), 3.49 (dd, $J=9.9,7.9 \mathrm{~Hz}, 1 \mathrm{H}$ ), $3.43(\mathrm{dd}, J=9.9,8.2 \mathrm{~Hz}, 1 \mathrm{H}), 3.21(\mathrm{dd}, J=9.9,7.9 \mathrm{~Hz}, 1 \mathrm{H}), 2.93(\mathrm{t}, J=9.3 \mathrm{~Hz}, 1 \mathrm{H}), 2.63$ (quintet, $J=8.5 \mathrm{~Hz}$, $1 \mathrm{H}), 2.44$ (s, 3H), 2.13 (qd, J = 8.4, $5.4 \mathrm{~Hz}, 1 \mathrm{H}), 1.79$ (br s, $1 \mathrm{H}) ;{ }^{13} \mathrm{C}-\mathrm{NMR}\left(101 \mathrm{MHz}, \mathrm{CDCl}_{3}\right.$ ): $\delta 143.42$, 142.59, 136.71, 133.39, 129.61, 128.54, 127.91, 127.61, 125.83, 117.03, 72.82, 52.74, 51.22, 48.32, 44.50, 21.53; [Chiracel ${ }^{\circledR} \mathrm{AD}$ column, eluting with $80: 20$ heptane/IPA, $0.8 \mathrm{~mL} / \mathrm{min}, 254 \mathrm{~nm}$; $\mathrm{t}_{\mathrm{r}}=40.0$ and 64.9 min, 95:5 e.r.]; HR-MS (m/z): [M + Na+] calcd for $\mathrm{C}_{20} \mathrm{H}_{23} \mathrm{NNaO}_{3} \mathrm{~S}$ : 380.1297; found: 380.1296 .

\section{(S)-((3S,4S)-1-(tert-butylsulfonyl)-4-vinylpyrrolidin-3-yl)(phenyl)methanol (6a)}

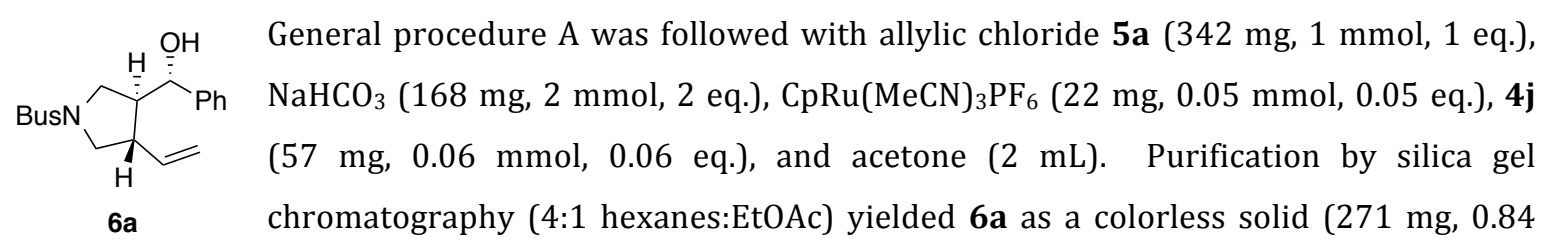
mmol, 84\% yield). $\left[\mathrm{R}_{\mathrm{f}}=0.19\right.$ (3:1 hexanes:EtOAc)]; $[\alpha]_{\mathrm{D}}{ }^{25}=-21.91^{\circ}\left(1.0, \mathrm{CHCl}_{3}\right)$; IR (thin film): 3497, 2980, 2901, 1479, 1454, 1395, 1365, 1307, 1197, 1128, 1110, 1019, 920, 814, 760, 703, 671, 621, 581, $513 \mathrm{~cm}^{-1}$; ${ }^{1} \mathrm{H}-\mathrm{NMR}\left(400 \mathrm{MHz} ; \mathrm{CDCl}_{3}\right): \delta$ 7.34-7.27 (m, 5H), 5.60-5.51 (m, 1H), 5.05-5.00 (m, 2H), $4.73(\mathrm{~d}, J$ 
$=5.1 \mathrm{~Hz}, 1 \mathrm{H}$ ), $3.69(\mathrm{dt}, J=15.9,8.3 \mathrm{~Hz}, 2 \mathrm{H}), 3.44(\mathrm{t}, J=9.0 \mathrm{~Hz}, 1 \mathrm{H}), 3.24(\mathrm{t}, J=9.5 \mathrm{~Hz}, 1 \mathrm{H}$ ), 2.84 (quintet, $J$ $=8.6 \mathrm{~Hz}, 1 \mathrm{H}), 2.30(\mathrm{qd}, J=8.4,5.1 \mathrm{~Hz}, 1 \mathrm{H}), 1.79(\mathrm{br} \mathrm{s}, 1 \mathrm{H}), 1.37(\mathrm{~s}, 9 \mathrm{H}) ;{ }^{13} \mathrm{C}-\mathrm{NMR}\left(101 \mathrm{MHz}, \mathrm{CDCl}_{3}\right): \delta$ 143.08, 137.05, 128.84, 128.12, 126.07, 117.54, 72.76, 61.43, 54.67, 52.09, 49.88, 45.71, 24.72; [Chiracel ${ }^{\circledR}$ AD column, eluting with 95:5 heptane/IPA, $0.8 \mathrm{~mL} / \mathrm{min}, 220 \mathrm{~nm}$; $\mathrm{t}_{\mathrm{r}}=30.1$ and $43.7 \mathrm{~min}, 98: 2$ e.r.]; HR-MS (m/z): [M + Na+] calcd for $\mathrm{C}_{17} \mathrm{H}_{25} \mathrm{NNaO}_{3} \mathrm{~S}$ : 346.1453; found: 346.1453 .

(S)-((3S,4S)-1-(tert-butylsulfonyl)-4-vinylpyrrolidin-3-yl)(4-chlorophenyl)methanol (6b) General

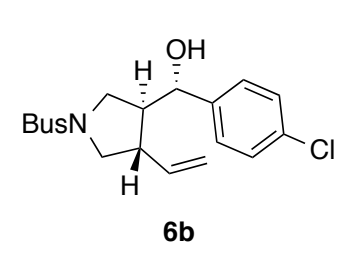

procedure A was followed with allylic chloride $5 \mathbf{b}$ (38 $\mathrm{mg}, 0.1 \mathrm{mmol}, 1$ eq.), $\mathrm{NaHCO}_{3}$ (8.4 mg, $0.1 \mathrm{mmol}, 1$ eq.), $\mathrm{CpRu}(\mathrm{MeCN})_{3} \mathrm{PF}_{6}(2.2 \mathrm{mg}, 0.005 \mathrm{mmol}, 0.05$ eq.), $4 \mathbf{j}$ (5.7 mg, $0.006 \mathrm{mmol}, 0.06$ eq.), and acetone ( $0.2 \mathrm{~mL}$ ). Purification by silica gel chromatography (9:1 hexanes:EtOAc) yielded $\mathbf{6 b}$ as a yellow-white solid (23 mg, $0.064 \mathrm{mmol}, 64 \%$ yield). [ $\mathrm{R}_{\mathrm{f}}=0.19$ (3:1 hexanes:EtOAc)]; $[\alpha]_{\mathrm{D}}{ }^{25}=$

$-17.85^{\circ}$ (1.0, $\mathrm{CHCl}_{3}$ ); IR (thin film): 3494, 2924, 1489, 1395, 1365, 1304, 1203, 1124, 1109, 1089, 1013, $918,810,792,731,670,581,552,512 \mathrm{~cm}^{-1} ;{ }^{1} \mathrm{H}-\mathrm{NMR}\left(400 \mathrm{MHz}\right.$; $\left.\mathrm{CDCl}_{3}\right): \delta$ 7.33-7.22 (m, 5H), $5.53(\mathrm{dt}, J=$ 17.4, 8.9 Hz, 1H), 5.05-5.00 (m, 2H), 4.69 (d, J = 4.9 Hz, 1H), $3.70(\mathrm{t}, J=8.6 \mathrm{~Hz}, 1 \mathrm{H}), 3.62(\mathrm{t}, J=9.4 \mathrm{~Hz}, 1 \mathrm{H})$, $3.38(\mathrm{t}, J=8.9 \mathrm{~Hz}, 1 \mathrm{H}), 3.20(\mathrm{t}, J=9.6 \mathrm{~Hz}, 1 \mathrm{H}), 2.80$ (quintet, $J=8.5 \mathrm{~Hz}, 1 \mathrm{H}), 2.24(\mathrm{~m}, 1 \mathrm{H}), 1.35(\mathrm{~s}, 9 \mathrm{H})$; ${ }^{13} \mathrm{C}-\mathrm{NMR}\left(101 \mathrm{MHz}, \mathrm{CDCl}_{3}\right): \delta 141.67,136.86,129.09,128.93,127.49,117.77,72.01,61.43,54.67,52.09$, 49.82, 45.72, 24.68; [Chiracel@ AD column, eluting with 95:5 heptane $/ \mathrm{IPA}, 0.8 \mathrm{~mL} / \mathrm{min}, 220 \mathrm{~nm}$; $\mathrm{t}_{\mathrm{r}}=$ 93.0 and $97.11 \mathrm{~min}, 98: 2$ e.r.]; HR-MS (m/z): $\left[\mathrm{M}+\mathrm{Na}^{+}\right]$calcd for $\mathrm{C}_{17} \mathrm{H}_{24} \mathrm{ClNNaO}_{3} \mathrm{~S}: 380.1063$; found: 380.1063 .

\section{(S)-(4-bromophenyl)((3S,4S)-1-(tert-butylsulfonyl)-4-vinylpyrrolidin-3-yl)methanol (6c)}

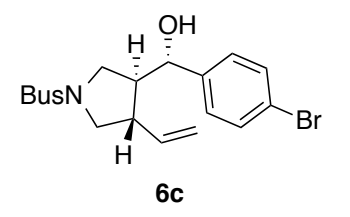

General procedure A was followed with allylic chloride 5c (42 mg, $0.1 \mathrm{mmol}, 1$ eq.), $\mathrm{NaHCO}_{3}$ (8.4 mg, $0.1 \mathrm{mmol}, 1$ eq.), $\mathrm{CpRu}(\mathrm{MeCN})_{3} \mathrm{PF}_{6}(2.2 \mathrm{mg}, 0.005 \mathrm{mmol}$, 0.05 eq.), 4 j (5.7 mg, $0.006 \mathrm{mmol}, 0.06$ eq.), and acetone (0.2 mL). Purification by silica gel chromatography (9:1 hexanes:EtOAc) yielded $\mathbf{6 c}$ as a yellow-white solid (17 mg, $0.042 \mathrm{mmol}, 42 \%$ yield). [ $\mathrm{R}_{\mathrm{f}}=0.19$ (3:1 hexanes:EtOAc)]; $[\alpha]_{\mathrm{D}}{ }^{25}=-15.44^{\circ}\left(1.0, \mathrm{CHCl}_{3}\right) ; \mathrm{IR}$ (thin film): 3483, 2924, 1485, 1395, 1365, 1304, 1205, 1125, 1109, 1070, 1009, 918, 811, 791, 732, 670, 581, 549, $512 \mathrm{~cm}^{-1} ;{ }^{1} \mathrm{H}-\mathrm{NMR}\left(400 \mathrm{MHz} ; \mathrm{CDCl}_{3}\right): \delta 7.46(\mathrm{~d}, J=8.3 \mathrm{~Hz}, 2 \mathrm{H}), 7.18(\mathrm{~d}, J=8.3 \mathrm{~Hz}, 2 \mathrm{H}), 5.54$ (ddd, $J=17.1,10.1,8.4 \mathrm{~Hz}, 1 \mathrm{H}), 5.06-5.02(\mathrm{~m}, 2 \mathrm{H}), 4.69(\mathrm{~d}, J=5.0 \mathrm{~Hz}, 1 \mathrm{H}), 3.71(\mathrm{t}, J=8.9 \mathrm{~Hz}, 1 \mathrm{H}), 3.63(\mathrm{t}, J$ $=9.2 \mathrm{~Hz}, 1 \mathrm{H}), 3.38(\mathrm{t}, J=8.9 \mathrm{~Hz}, 1 \mathrm{H}), 3.21(\mathrm{t}, J=9.6 \mathrm{~Hz}, 1 \mathrm{H}), 2.81$ (quintet, $J=8.6 \mathrm{~Hz}, 1 \mathrm{H}), 2.25(\mathrm{qd}, J=8.5$, $5.0 \mathrm{~Hz}, 1 \mathrm{H}), 1.62$ (br s, 1H), 1.36 (s, 9H); ${ }^{13} \mathrm{C}-\mathrm{NMR}\left(101 \mathrm{MHz}, \mathrm{CDCl}_{3}\right): \delta$ 142.15, 136.85, 132.04, 131.90, 127.81, 117.82, 72.05, 61.42, 54.67, 52.05, 49.76, 45.74, 24.69; [Chiracel ${ }^{\circledR}$ AD column, eluting with 95:5 heptane/IPA, $0.8 \mathrm{~mL} / \mathrm{min}, 220 \mathrm{~nm}$; $\mathrm{t}_{\mathrm{r}}=101.8$ and $106.2 \mathrm{~min}, 98: 2$ e.r.]; HR-MS (m/z): [M + $\left.\mathrm{Na}^{+}\right]$calcd for $\mathrm{C}_{17} \mathrm{H}_{24} \mathrm{BrNNaO}_{3} \mathrm{~S}$ : 424.0558; found: 424.0558 . 


\section{(S)-((3S,4S)-1-(tert-butylsulfonyl)-4-vinylpyrrolidin-3-yl)(4-methoxyphenyl)methanol (6d)}

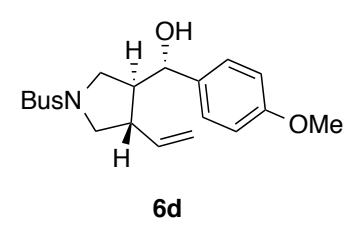

General procedure A was followed with allylic chloride $\mathbf{5 d}(37 \mathrm{mg}, 0.1 \mathrm{mmol}, 1$ eq.), $\mathrm{NaHCO}_{3}$ (8.4 mg, $0.1 \mathrm{mmol}, 1$ eq.), $\mathrm{CpRu}(\mathrm{MeCN})_{3} \mathrm{PF}_{6}(2.2 \mathrm{mg}, 0.005 \mathrm{mmol}$, 0.05 eq.), 4 j ( $5.7 \mathrm{mg}, 0.006 \mathrm{mmol}, 0.06$ eq.), and acetone $/ \mathrm{H}_{2} \mathrm{O}(0.2 \mathrm{~mL}, 95: 5$ v/v). Purification by silica gel chromatography (4:1 hexanes:EtOAc) yielded $\mathbf{6 d}$ as a clear oil (30 mg, $0.085 \mathrm{mmol}, 85 \%$ yield). $\left[\mathrm{R}_{\mathrm{f}}=0.1\right.$ (3:1 hexanes:EtOAc)]; $[\alpha]_{\mathrm{D}}^{25}=-26.71^{\circ}\left(1.0, \mathrm{CHCl}_{3}\right)$; IR (thin film): 3498, 2976, 1643, 1612, 1511, 1479, 1464, 1394, 1365, 1303, 1245, 1174, 1127, 1109, 1031, 918, 831, 812, 794, 766, 732, 671, 581, $513 \mathrm{~cm}^{-1} ;{ }^{1} \mathrm{H}-\mathrm{NMR}\left(400 \mathrm{MHz} ; \mathrm{CDCl}_{3}\right): \delta 7.21(\mathrm{~d}, J=8.6 \mathrm{~Hz}$, $2 \mathrm{H}), 6.86(\mathrm{~d}, J=8.6 \mathrm{~Hz}, 2 \mathrm{H}), 5.52(\mathrm{ddd}, J=17.4,9.7,8.1 \mathrm{~Hz}, 1 \mathrm{H}), 5.02-4.97(\mathrm{~m}, 2 \mathrm{H}), 4.65(\mathrm{~d}, J=5.5 \mathrm{~Hz}, 1 \mathrm{H})$, $3.80(\mathrm{~s}, 3 \mathrm{H}), 3.67(\mathrm{q}, J=9.5 \mathrm{~Hz}, 2 \mathrm{H}), 3.47(\mathrm{t}, J=8.9 \mathrm{~Hz}, 1 \mathrm{H}), 3.22(\mathrm{t}, J=9.5 \mathrm{~Hz}, 1 \mathrm{H}), 2.77$ (quintet, $J=8.4$ $\mathrm{Hz}, 1 \mathrm{H}), 2.28(\mathrm{dt}, J=14.6,7.6 \mathrm{~Hz}, 1 \mathrm{H}), 1.99(\mathrm{br} \mathrm{s}, 1 \mathrm{H}), 1.37$ (s, 9H); ${ }^{13} \mathrm{C}-\mathrm{NMR}\left(101 \mathrm{MHz}, \mathrm{CDCl}_{3}\right): \delta 159.42$, 137.16, 135.21, 127.38, 117.29, 114.13, 72.72, 61.42, 55.54, 54.62, 52.18, 50.24, 45.69, 24.73; [Chiracel@ AD column, eluting with 70:30 heptane/IPA, $0.8 \mathrm{~mL} / \mathrm{min}, 254 \mathrm{~nm}$; $\mathrm{t}_{\mathrm{r}}=16.5$ and $17.8 \mathrm{~min}, 94: 6$ e.r.]; HRMS (m/z): [M + Na+] calcd for $\mathrm{C}_{18} \mathrm{H}_{27} \mathrm{NNaO}_{4} \mathrm{~S}$ : 376.1559; found: 376.1559 .

\section{(S)-((3S,4S)-1-(tert-butylsulfonyl)-4-vinylpyrrolidin-3-yl)(o-tolyl)methanol (6e)}

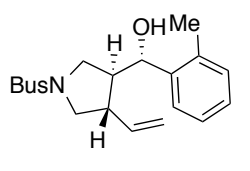

$6 e$ General procedure A was followed with allylic chloride $\mathbf{5 e}$ (36 mg, $0.1 \mathrm{mmol}, 1 \mathrm{eq}$.$) ,$ $\mathrm{NaHCO}_{3}$ (8.4 mg, $0.1 \mathrm{mmol}, 1$ eq.), $\mathrm{CpRu}(\mathrm{MeCN})_{3} \mathrm{PF}_{6}$ (2.2 mg, $0.005 \mathrm{mmol}, 0.05$ eq.), 4j (5.7 mg, $0.006 \mathrm{mmol}, 0.06$ eq.), and acetone (0.2 mL). Purification by silica gel chromatography (9:1 hexanes:EtOAc) yielded $\mathbf{6 e}$ as a yellow-white solid $(21 \mathrm{mg}$, $0.062 \mathrm{mmol}, 62 \%$ yield). $\left[\mathrm{R}_{\mathrm{f}}=0.24\right.$ (3:1 hexanes:EtOAc)]; $[\alpha]_{\mathrm{D}}{ }^{25}=-29.36^{\circ}\left(1.0, \mathrm{CHCl}_{3}\right) ; \mathrm{IR}$ (thin film): 3496, 2923, 1737, 1643, 1480, 1460, 1394, 1365, 1305, 1207, 1128, 1109, 1018, 917, 815, 782, 758, 730, 670, 621, 581, $512 \mathrm{~cm}^{-1} ;{ }^{1} \mathrm{H}-\mathrm{NMR}\left(400 \mathrm{MHz} ; \mathrm{CDCl}_{3}\right.$ ): $\delta$ 7.42-7.40 (m, 1H), 7.22-7.10 (m, 3H), 5.59 (ddd, $J$ $=17.1,10.1,8.5 \mathrm{~Hz}, 1 \mathrm{H}), 5.13(\mathrm{~d}, J=17.1 \mathrm{~Hz}, 1 \mathrm{H}), 5.07(\mathrm{~d}, J=10.1 \mathrm{~Hz}, 1 \mathrm{H}), 5.02(\mathrm{~d}, J=4.0 \mathrm{~Hz}, 1 \mathrm{H}), 3.74-$ $3.68(\mathrm{~m}, 2 \mathrm{H}), 3.38(\mathrm{t}, J=8.9 \mathrm{~Hz}, 1 \mathrm{H}), 3.25(\mathrm{t}, J=9.8 \mathrm{~Hz}, 1 \mathrm{H}), 2.91$ (quintet, $J=8.8 \mathrm{~Hz}, 1 \mathrm{H}), 2.25-2.23(\mathrm{~m}$, 4H), 1.37 (s, 9H); ${ }^{13} \mathrm{C}-\mathrm{NMR}\left(101 \mathrm{MHz}, \mathrm{CDCl}_{3}\right): \delta$ 141.36, 136.84, 134.19, 130.77, 127.71, 126.62, 125.33, 117.91, 68.14, 61.44, 54.76, 50.23, 49.39, 45.94, 24.73, 19.21; [Chiracel@ IB column, eluting with 98:2 heptane/IPA, $0.8 \mathrm{~mL} / \mathrm{min}, 220 \mathrm{~nm}$; $\mathrm{t}_{\mathrm{r}}=39.0$ and $44.3 \mathrm{~min}, 97: 3$ e.r.]; HR-MS (m/z): [M+ $\left.\mathrm{Na}^{+}\right]$calcd for $\mathrm{C}_{18} \mathrm{H}_{27} \mathrm{NNaO}_{3} \mathrm{~S}: 360.1610$; found: 360.1609 .

\section{(S)-1-((3S,4S)-1-(tert-butylsulfonyl)-4-vinylpyrrolidin-3-yl)-1-phenylethan-1-ol (6f)}

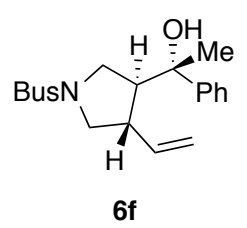

General procedure A was followed with allylic chloride $5 \mathbf{f}$ (36 mg, $0.1 \mathrm{mmol}, 1 \mathrm{eq}$.$) ,$ $\mathrm{NaHCO}_{3}$ (8.4 mg, 0.1 mmol, 1 eq.), $\mathrm{CpRu}(\mathrm{MeCN})_{3} \mathrm{PF}_{6}$ (2.2 mg, 0.005 mmol, 0.05 eq.), $4 \mathbf{j}$ (5.7 mg, $0.006 \mathrm{mmol}, 0.06$ eq.), and acetone $(0.2 \mathrm{~mL})$. Purification by silica gel chromatography (7:1 hexanes:EtOAc) yielded $\mathbf{6 f}$ as a white solid (23 $\mathrm{mg}, 0.071 \mathrm{mmol}$, $71 \%$ yield). $\left[\mathrm{R}_{\mathrm{f}}=0.25\right.$ (3:1 hexanes:EtOAc)]; $[\alpha]_{\mathrm{D}} 25=-9.87^{\circ}\left(1.0, \mathrm{CHCl}_{3}\right) ;$ IR (thin film): 3500, 2977, 2929, $1641,1479,1446,1394,1365,1306,1208,1116,1068,1019,917,814,765,702,672,639,589,512 \mathrm{~cm}^{-}$ 
1; ${ }^{1} \mathrm{H}-\mathrm{NMR}\left(400 \mathrm{MHz} ; \mathrm{CDCl}_{3}\right): \delta$ 7.41-7.39 (m, 2H), 7.35-7.31 (m, 2H), 7.26-7.21 (m, 1H), 5.82 (ddd, $J=$ 17.1, 10.2, 8.4 Hz, 1H), 5.17 (d, $J=17.1 \mathrm{~Hz}, 1 \mathrm{H}), 5.08(\mathrm{~d}, J=10.2 \mathrm{~Hz}, 1 \mathrm{H}), 3.68(\mathrm{t}, J=9.1 \mathrm{~Hz}, 1 \mathrm{H}), 3.30-3.18$ (m, 3H), 3.08 (quintet, $J=8.4 \mathrm{~Hz}, 1 \mathrm{H}), 2.55$ (q, $J=8.1 \mathrm{~Hz}, 1 \mathrm{H}), 2.23(\mathrm{br} \mathrm{s}, 1 \mathrm{H}), 1.55(\mathrm{~s}, 3 \mathrm{H}), 1.30(\mathrm{~s}, 9 \mathrm{H})$; ${ }^{13} \mathrm{C}-\mathrm{NMR}\left(101 \mathrm{MHz}, \mathrm{CDCl}_{3}\right): \delta$ 139.91, 128.62, 127.16, 124.97, 124.88, 116.61, 75.54, 61.22, 55.80, 54.99,

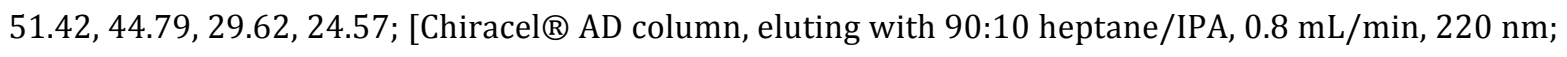
$\mathrm{t}_{\mathrm{r}}=26.8$ and $31.9 \mathrm{~min}, 96: 4$ e.r.]; HR-MS (m/z): [M + $\left.\mathrm{Na}^{+}\right]$calcd for $\mathrm{C}_{18} \mathrm{H}_{27} \mathrm{NNaO}_{3} \mathrm{~S}: 360.1610$; found: 360.1609 .

(S)-1-((3S,4S)-1-(tert-butylsulfonyl)-4-vinylpyrrolidin-3-yl)-1-(3-methoxyphenyl)ethan-1-ol (6g) General procedure A was followed with allylic chloride $\mathbf{5 g}(17 \mathrm{mg}, 0.05 \mathrm{mmol}, 1$

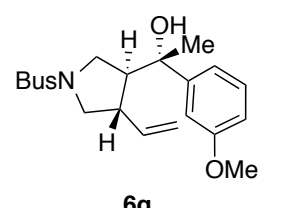
eq.), $\mathrm{NaHCO}_{3}$ (4.2 mg, $0.05 \mathrm{mmol}, 1$ eq.), $\mathrm{CpRu}(\mathrm{MeCN})_{3} \mathrm{PF}_{6}(1.1 \mathrm{mg}, 0.0025 \mathrm{mmol}$, 0.05 eq.), $4 \mathbf{j}$ ( $2.8 \mathrm{mg}, 0.003 \mathrm{mmol}, 0.06$ eq.), and acetone (0.1 mL). Purification by silica gel chromatography (4:1 hexanes:EtOAc) yielded $\mathbf{6 g}$ as a white solid $(11 \mathrm{mg}$, $0.060 \mathrm{mmol}, 60 \%$ yield). [ $\mathrm{R}_{\mathrm{f}}=0.19$ (3:1 hexanes:EtOAc)]; $[\alpha]_{\mathrm{D}} 25=-16.51^{\circ} \quad(1.0$, $\mathrm{CHCl}_{3}$ ); IR (thin film): 3500, 2975, 2932, 1738, 1641, 1600, 1582, 1485, 1455, 1432, 1394, 1365, 1305, 1256, 1117, 1037, 917, 869, 811, 783, 732, 704, 671, 582, $512 \mathrm{~cm}^{-1}$; ${ }^{1} \mathrm{H}-\mathrm{NMR}\left(400 \mathrm{MHz}\right.$; $\left.\mathrm{CDCl}_{3}\right): \delta 7.25(\mathrm{t}$, $J=7.9 \mathrm{~Hz}, 1 \mathrm{H}), 6.98-6.93(\mathrm{~m}, 2 \mathrm{H}), 6.78(\mathrm{dd}, J=7.9,2.2 \mathrm{~Hz}, 1 \mathrm{H}), 5.83(\mathrm{ddd}, J=17.1,10.8,8.4 \mathrm{~Hz}, 1 \mathrm{H}), 5.18$ (d, $J=17.1 \mathrm{~Hz}, 1 \mathrm{H}), 5.08(\mathrm{~d}, J=10.8 \mathrm{~Hz}, 1 \mathrm{H}), 3.81(\mathrm{~s}, 3 \mathrm{H}), 3.69(\mathrm{dd}, J=10.2,7.9 \mathrm{~Hz}, 1 \mathrm{H}), 3.30-3.18(\mathrm{~m}$, 3H), 3.09 (quintet, $J=8.4 \mathrm{~Hz}, 1 \mathrm{H}$ ), $2.53(\mathrm{q}, J=8.1 \mathrm{~Hz}, 1 \mathrm{H}), 2.19$ (br s, $1 \mathrm{H}), 1.54(\mathrm{~s}, 3 \mathrm{H}), 1.31(\mathrm{~s}, 9 \mathrm{H})$; ${ }^{13} \mathrm{C}-$ $\operatorname{NMR}\left(101 \mathrm{MHz}, \mathrm{CDCl}_{3}\right): \delta$ 159.85, 149.22, 140.02, 139.94, 129.68, 117.27, 116.61, 112.01, 111.18, 75.51, 61.22, 55.81, 55.47, 54.87, 51.41, 44.78, 29.67, 24.57; [Chiracel ${ }^{\circ}$ AD column, eluting with 90:10 heptane/IPA, $0.8 \mathrm{~mL} / \mathrm{min}, 220 \mathrm{~nm}$; $\mathrm{t}_{\mathrm{r}}=26.6$ and $38.5 \mathrm{~min}, 97: 3$ e.r.]; HR-MS (m/z): [M + Na+] calcd for $\mathrm{C}_{19} \mathrm{H}_{29} \mathrm{NNaO}_{4} \mathrm{~S}$ : 390.1715 ; found: 390.1715 .

\section{(S)-phenyl((3S,4S)-4-vinyltetrahydrofuran-3-yl)methanol (8)}

General procedure $\mathrm{A}$ was followed with allylic chloride 7 (22 mg, $0.1 \mathrm{mmol}, 1 \mathrm{eq})$,
$\mathbf{8}$ $\begin{aligned} & \mathrm{NaHCO}_{3}(8.4 \mathrm{mg}, 0.1 \mathrm{mmol}, 1 \mathrm{eq} .), \mathrm{CpRu}\left(\mathrm{MeCN}_{3} \mathrm{PF}_{6}(2.2 \mathrm{mg}, 0.005 \mathrm{mmol}, 0.05 \mathrm{eq} .), 4 \mathbf{j}(5.7\right. \\ & \text { chromatography }(3: 1 \text { hexanes:EtOAc) yielded } 8 \text { as a clear liquid }(15 \mathrm{mg}, 0.073 \mathrm{mmol}, 73 \%\end{aligned}$ yield). $\left[\mathrm{R}_{\mathrm{f}}=0.19\right.$ (3:1 hexanes:EtOAc)]; $[\alpha]_{\mathrm{D}} 25=-21.40^{\circ}\left(1.0, \mathrm{CHCl}_{3}\right) ; \mathrm{IR}$ (thin film): 3399, 3063, 3028, 2929, 1738, 1641, 1494, 1454, 1421, 1204, 1055, 993, 916, 765, 702, 623, $544 \mathrm{~cm}^{-1}$; ${ }^{1} \mathrm{H}-\mathrm{NMR}$ (400 MHz; $\left.\mathrm{CDCl}_{3}\right): \delta 7.36-7.27(\mathrm{~m}, 5 \mathrm{H}), 5.49(\mathrm{ddd}, J=17.0,10.2,8.5 \mathrm{~Hz}, 1 \mathrm{H}), 4.79(\mathrm{~d}, J=10.2 \mathrm{~Hz}, 1 \mathrm{H}), 4.72(\mathrm{~d}, J=$ $17.0 \mathrm{~Hz}, 1 \mathrm{H}), 4.64(\mathrm{~d}, J=6.9 \mathrm{~Hz}, 1 \mathrm{H}), 4.00(\mathrm{~m}, 2 \mathrm{H}), 3.88(\mathrm{t}, J=8.3 \mathrm{~Hz}, 1 \mathrm{H}), 3.47(\mathrm{t}, J=8.3 \mathrm{~Hz}, 1 \mathrm{H}), 2.63$ (quintet, $J=7.8 \mathrm{~Hz}, 1 \mathrm{H}$ ), 2.36 (quintet, $J=6.9 \mathrm{~Hz}, 1 \mathrm{H}) ;{ }^{13} \mathrm{C}-\mathrm{NMR}\left(101 \mathrm{MHz}, \mathrm{CDCl}_{3}\right): \delta 138.09,128.72$, $128.14,126.76,126.65,115.92,75.47,73.48,70.46,53.07,46.78$; HR-MS (m/z): $\left[\mathrm{M}+\mathrm{Na}^{+}\right]$calcd for $\mathrm{C}_{13} \mathrm{H}_{16} \mathrm{NaO}_{2}$ : 227.1048; found: 227.1048. 


\section{O-Methylmandelate Analysis of 8 viii}

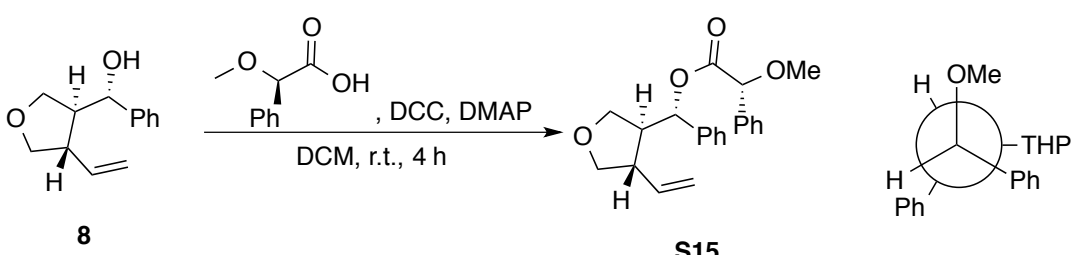

A vial with stir bar was charged with a $0.2 \mathrm{~mL}$ solution of 8 (3 mg, $0.015 \mathrm{mmol}, 1 \mathrm{eq}$.) in DCM. (R)-0methylmendelic acid (2.5 mg, $0.015 \mathrm{mmol}, 1$ eq.), DCC ( $3 \mathrm{mg}, 0.015 \mathrm{mmol}, 1$ eq.), and DMAP (0.2 mg, $0.0015 \mathrm{mmol}, 0.1 \mathrm{eq}$.) were added sequentially and the reaction was allowed to stir at r.t. for 4 hours. TLC analysis indicated completion, so the reaction was diluted with ether, filtered, and concentrated. Purified via prep. TLC (3:1 hex:EtOAc); ${ }^{1} \mathrm{H}-\mathrm{NMR}\left(400 \mathrm{MHz} ; \mathrm{CDCl}_{3}\right): \delta$ 7.47-7.21 (m, 10H), $5.72(\mathrm{~d}, J=7.0$ $\mathrm{Hz}, 1 \mathrm{H}), 5.34(\mathrm{dt}, J=17.0,8.9 \mathrm{~Hz}, 1 \mathrm{H}), 4.77(\mathrm{~s}, 1 \mathrm{H}), 4.74(\mathrm{~d}, J=10.3 \mathrm{~Hz}, 1 \mathrm{H}), 4.53(\mathrm{~d}, J=17.0 \mathrm{~Hz}, 1 \mathrm{H}), 3.71$ $(\mathrm{t}, J=8.2 \mathrm{~Hz}, 1 \mathrm{H}), 3.56(\mathrm{t}, J=8.3 \mathrm{~Hz}, 1 \mathrm{H}), 3.42(\mathrm{t}, J=8.2 \mathrm{~Hz}, 1 \mathrm{H}), 3.36(\mathrm{~m}, 4 \mathrm{H}), 2.37(\mathrm{dt}, J=15.1,7.6 \mathrm{~Hz}$, $1 \mathrm{H}), 2.15(\mathrm{dt}, J=16.2,8.0 \mathrm{~Hz}, 1 \mathrm{H})$.
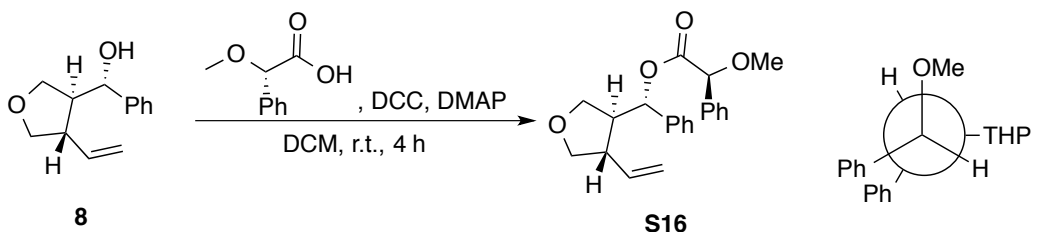

A vial with stir bar was charged with a $0.2 \mathrm{~mL}$ solution of 8 ( $3 \mathrm{mg}, 0.015 \mathrm{mmol}, 1 \mathrm{eq}$.) in DCM. (S)-Omethylmendelic acid (2.5 mg, $0.015 \mathrm{mmol}, 1$ eq.), DCC ( $3 \mathrm{mg}, 0.015 \mathrm{mmol}, 1 \mathrm{eq}$.), and DMAP (0.2 mg, $0.0015 \mathrm{mmol}, 0.1 \mathrm{eq}$.) were added sequentially and the reaction was allowed to stir at r.t. for 8 hours (reaction more sluggish than when performed with the $R$ enantiomer of $O$-methylmendelic acid). TLC analysis indicated completion, so the reaction was diluted with ether, filtered, and concentrated. Purified via prep. TLC (3:1 hex:EtOAc) ${ }^{1} \mathrm{H}$ NMR ( $\left.\mathrm{MHz}, \mathrm{CDCl}_{3}\right): \delta{ }^{1} \mathrm{H}-\mathrm{NMR}\left(400 \mathrm{MHz} ; \mathrm{CDCl}_{3}\right): \delta$ 7.38-7.32 (m, 5H), 7.18-7.14 (m, 3H), 6.96-6.93 (m, 2H), $5.73(\mathrm{~d}, J=6.3 \mathrm{~Hz}, 1 \mathrm{H}), 5.44(\mathrm{dt}, J=16.3,9.0 \mathrm{~Hz}, 1 \mathrm{H}), 4.82-$ $4.80(\mathrm{~m}, 2 \mathrm{H}), 4.69(\mathrm{~d}, J=17.3 \mathrm{~Hz}, 1 \mathrm{H}), 3.93(\mathrm{t}, J=7.8 \mathrm{~Hz}, 1 \mathrm{H}), 3.80(\mathrm{t}, J=7.9 \mathrm{~Hz}, 1 \mathrm{H}), 3.72(\mathrm{t}, J=7.4 \mathrm{~Hz}$, $1 \mathrm{H}), 3.46(\mathrm{t}, J=8.2 \mathrm{~Hz}, 1 \mathrm{H}), 3.39(\mathrm{~s}, 3 \mathrm{H}), 2.52-2.42(\mathrm{~m}, 2 \mathrm{H})$.

The $(R)$-methylmendelic ester shifts the THP ring protons on $\mathbf{S 1 5}$ upfield by $\sim 0.3 \mathrm{ppm}$ compared to the (S)-methylmendelic ester, indicating that the phenyl group on the $(R)$ ester is shielding these protons. Additionally, the $(S)$-methylmendelic ester shifts the phenyl ring protons on $\mathbf{S 1 6}$ by $\sim 0.2$ ppm upfield compared to the phenyl ring protons on S15, reinforcing the assignment of the alcohol of 8 as $(S)$. 


\section{dibenzyl (3R,4S)-3-(2-hydroxypropan-2-yl)-4-vinylcyclopentane-1,1-dicarboxylate (10)}

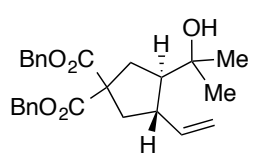

10

General procedure A was followed with allylic chloride 9 (44 mg, 0.1 mmol, 1 eq.), $\mathrm{NaHCO}_{3}$ (8.4 mg, $0.1 \mathrm{mmol}, 1$ eq.), $\mathrm{CpRu}(\mathrm{MeCN})_{3} \mathrm{PF}_{6}$ (3.3 mg, $0.0075 \mathrm{mmol}, 0.075$ eq.), 4j (8.6 mg, $0.009 \mathrm{mmol}, 0.09$ eq.), and acetone (0.2 mL). Purification by silica gel chromatography (9:1 hexanes:EtOAc) yielded $\mathbf{1 0}$ as a clear liquid (22 mg, 0.052 mmol, $52 \%$ yield). $\left[\mathrm{R}_{\mathrm{f}}=0.28\right.$ (3:1 hexanes:EtOAc)]; $[\alpha]_{\mathrm{D}}{ }^{25}=-11.10^{\circ}\left(1.0, \mathrm{CHCl}_{3}\right)$; IR (thin film): 3544 , $3034,2970,1728,1639,1498,1456,1374,1244,1172,1098,1029,1002,911,737,697,598 \mathrm{~cm}^{-1} ;{ }^{1} \mathrm{H}-$ NMR (400 MHz; $\left.\mathrm{CDCl}_{3}\right): \delta$ 7.32-7.29 (m, 5H), 7.26-7.22 (m, 5H), $5.74(\mathrm{dt}, J=17.2,9.4 \mathrm{~Hz}, 1 \mathrm{H}), 5.11-5.06$ $(\mathrm{m}, 5 \mathrm{H}), 4.97(\mathrm{~d}, J=10.1 \mathrm{~Hz}, 1 \mathrm{H}), 2.64(\mathrm{dt}, J=17.6,9.1 \mathrm{~Hz}, 1 \mathrm{H}), 2.51-2.43(\mathrm{~m}, 2 \mathrm{H}), 2.14-1.96(\mathrm{~m}, 3 \mathrm{H}), 1.16$ $(\mathrm{d}, J=8.4 \mathrm{~Hz}, 6 \mathrm{H}) ;{ }^{13} \mathrm{C}-\mathrm{NMR}\left(101 \mathrm{MHz}, \mathrm{CDCl}_{3}\right): \delta 172.36,172.06,142.74,135.59,128.75,128.53,128.30$, 128.26, 115.56, 72.58, 67.54, 67.47, 58.60, 55.36, 45.49, 41.63, 36.44, 28.91, 27.61; [Chiracel® AD column, eluting with 80:20 heptane/IPA, $0.8 \mathrm{~mL} / \mathrm{min}, 254 \mathrm{~nm}$; $\mathrm{t}_{\mathrm{r}}=19.0$ and $22.0 \mathrm{~min}, 94: 6$ e.r.]; HR-MS (m/z): $\left[\mathrm{M}+\mathrm{Na}^{+}\right]$calcd for $\mathrm{C}_{26} \mathrm{H}_{30} \mathrm{NaO}_{5}: 445.1991$; found: 445.1991.

\section{2-((1R,2S)-4,4-bis(phenylsulfonyl)-2-vinylcyclopentyl)propan-2-ol (12a)}

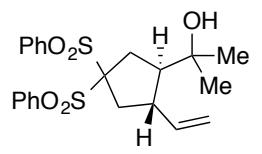

$12 a$

General procedure A was followed with allylic chloride 11a (45 mg, $0.1 \mathrm{mmol}, 1$ eq.), $\mathrm{NaHCO}_{3}$ (8.4 mg, 0.1 mmol, 1 eq.), $\mathrm{CpRu}(\mathrm{MeCN})_{3} \mathrm{PF}_{6}(2.2 \mathrm{mg}, 0.005 \mathrm{mmol}, 0.05$ eq.), 4j ( $5.7 \mathrm{mg}, 0.006 \mathrm{mmol}, 0.06 \mathrm{eq}$.$) , and acetone (0.2 \mathrm{~mL}$ ). Purification by silica gel chromatography (first by 2:1 hexanes:EtOAc, then a 2 nd column by 30:1 DCM:Et 20 ) yielded 12a as a white solid (31 mg, $0.071 \mathrm{mmol}, 71 \%$ yield). $\left[\mathrm{R}_{\mathrm{f}}=0.07\right.$ (3:1 hexanes:EtOAc)]; $[\alpha]_{\mathrm{D}}{ }^{25}=-$ $15.56^{\circ}\left(1.0, \mathrm{CHCl}_{3}\right.$ ); IR (thin film): 3546, 3070, 2972, 1640, 1583, 1447, 1375, 1324, 1308, 1213, 1140, $1077,1024,998,912,831,758,727,687,667,649,695,589,570,560 \mathrm{~cm}^{-1} ;{ }^{1} \mathrm{H}-\mathrm{NMR}$ (400 MHz; $\mathrm{CDCl}_{3}$ ): $\delta$ 8.09-8.05 (m, 3H), 8.09-8.05 (m, 4H), $7.73(\mathrm{t}, J=7.4 \mathrm{~Hz}, 2 \mathrm{H}), 7.73(\mathrm{t}, J=7.4 \mathrm{~Hz}, 2 \mathrm{H}), 7.61(\mathrm{t}, J=7.8 \mathrm{~Hz}$, $3 \mathrm{H}), 7.61(\mathrm{t}, J=7.8 \mathrm{~Hz}, 4 \mathrm{H}), 5.71-5.62(\mathrm{~m}, 1 \mathrm{H}), 5.71-5.62(\mathrm{~m}, 1 \mathrm{H}), 5.05(\mathrm{t}, J=14.5 \mathrm{~Hz}, 2 \mathrm{H}), 5.05(\mathrm{app} . \mathrm{t}, J=$ $14.5 \mathrm{~Hz}, 2 \mathrm{H}), 2.66-2.35(\mathrm{~m}, 4 \mathrm{H}), 2.66-2.35(\mathrm{~m}, 5 \mathrm{H}), 1.93$ (td, $J=11.3,7.5 \mathrm{~Hz}, 1 \mathrm{H}), 1.93(\mathrm{td}, J=11.3,7.5 \mathrm{~Hz}$, 1H), $1.67(\mathrm{~s}, 1 \mathrm{H}), 1.67(\mathrm{~s}, 1 \mathrm{H}), 1.14(\mathrm{~d}, J=12.3 \mathrm{~Hz}, 5 \mathrm{H}), 1.14(\mathrm{~d}, J=12.3 \mathrm{~Hz}, 6 \mathrm{H}) ;{ }^{13} \mathrm{C}-\mathrm{NMR}(101 \mathrm{MHz}$, $\left.\mathrm{CDCl}_{3}\right): \delta 140.77,136.44,136.36,134.97,134.96,131.67,131.57,129.05,117.23,90.80,71.87,55.50$, 46.13, 39.49, 34.57, 28.74, 27.82; [Chiracel ${ }^{\circledR}$ AD column, eluting with 60:40 heptane/IPA, $0.8 \mathrm{~mL} / \mathrm{min}$, $254 \mathrm{~nm} ; \mathrm{t}_{\mathrm{r}}=22.8$ and $26.8 \mathrm{~min}, 94: 6$ e.r.]; HR-MS (m/z): $\left[\mathrm{M}+\mathrm{Na}^{+}\right]$calcd for $\mathrm{C}_{22} \mathrm{H}_{26} \mathrm{NaO}_{5} \mathrm{~S}_{2}: 457.1120$; found: 457.1119 .

\section{(S)-((1R,2S)-4,4-bis(phenylsulfonyl)-2-vinylcyclopentyl)(phenyl)methanol (12b)}

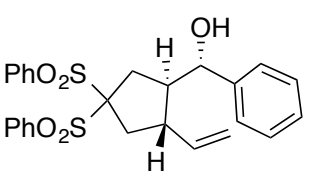

$12 b$

General procedure A was followed with allylic chloride 11b $(200 \mathrm{mg}, 0.4$ mmol, 1 eq.), $\mathrm{NaHCO}_{3}$ (34 mg, 0.4 mmol, 1 eq.), $\mathrm{CpRu}(\mathrm{MeCN})_{3} \mathrm{PF}_{6}$ (8.8 mg, 0.02 mmol, 0.05 eq.), $4 \mathbf{j}$ (23 mg, $0.024 \mathrm{mmol}, 0.06$ eq.), and acetone (0.8 mL). Purification by silica gel chromatography (3:1 hexanes:EtOAc) yielded 12a as a white solid $\left(140 \mathrm{mg}, 0.28 \mathrm{mmol}, 76 \%\right.$ yield). $\left[\mathrm{R}_{\mathrm{f}}=0.12\right.$ (3:1 hexanes:EtOAc)]; $[\alpha]_{\mathrm{D}}{ }^{25}=-36.93^{\circ}(1.0$, 
$\mathrm{CHCl}_{3}$ ); IR (thin film): 3539, 3064, 3029, 2924, 1642, 1583, 1494, 1478, 1447, 1325, 1309, 1204, 1181, $1142,1104,1076,1025,999,912,730,688,650,609,572,559,541 \mathrm{~cm}^{-1} ;{ }^{1} \mathrm{H}-\mathrm{NMR}\left(400 \mathrm{MHz} ; \mathrm{CDCl}_{3}\right): \delta$ 8.09 (d, $J=8.1 \mathrm{~Hz}, 2 \mathrm{H}), 7.89$ (d, $J=7.5 \mathrm{~Hz}, 2 \mathrm{H}), 7.69(\mathrm{~m}, 2 \mathrm{H}), 7.60(\mathrm{t}, J=7.5 \mathrm{~Hz}, 2 \mathrm{H}), 7.48$ (t, $J=7.8 \mathrm{~Hz}$, 2H), 7.32-7.23 (m, 3H), 7.17 (d, $J=7.1 \mathrm{~Hz}, 2 \mathrm{H}), 5.51(\mathrm{dt}, J=17.4,8.8 \mathrm{~Hz}, 1 \mathrm{H}), 5.04(\mathrm{~d}, J=12.8 \mathrm{~Hz}, 2 \mathrm{H})$, $4.68(\mathrm{~s}, 1 \mathrm{H}), 2.81-2.60(\mathrm{~m}, 4 \mathrm{H}), 2.41-2.35(\mathrm{~m}, 1 \mathrm{H}), 2.25$ (dd, $J=15.5,7.1 \mathrm{~Hz}, 1 \mathrm{H}) ;{ }^{13} \mathrm{C}-\mathrm{NMR}(101 \mathrm{MHz}$, $\left.\mathrm{CDCl}_{3}\right): \delta 143.37,138.18,136.49,136.36,134.86,134.74,131.72,131.43,128.98,128.95,128.66$, 127.69, 125.59, 117.94, 91.22, 71.09, 52.51, 45.95, 38.47, 31.47; [Chiracel® IB column, eluting with 90:10 heptane/IPA, $0.8 \mathrm{~mL} / \mathrm{min}, 220 \mathrm{~nm}$; $\mathrm{t}_{\mathrm{r}}=22.7$ and $28.2 \mathrm{~min}, 94: 6$ e.r.]; HR-MS (m/z): [M + $\left.\mathrm{Na}^{+}\right]$calcd for $\mathrm{C}_{26} \mathrm{H}_{26} \mathrm{NaO}_{5} \mathrm{~S}_{2}$ : 505.1120; found: 505.1119.

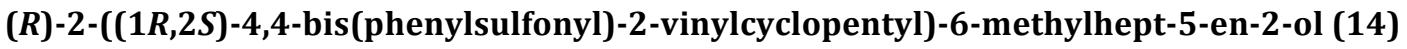

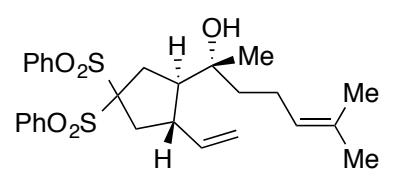

14

General procedure A was followed with allylic chloride $13(52 \mathrm{mg}, 0.1 \mathrm{mmol}$, 1 eq.), $\mathrm{NaHCO}_{3}$ (8.4 mg, $0.1 \mathrm{mmol}, 1$ eq.), $\mathrm{CpRu}(\mathrm{MeCN})_{3} \mathrm{PF}_{6}(2.2 \mathrm{mg}, 0.005$ mmol, 0.05 eq.), 4 j (5.7 mg, $0.006 \mathrm{mmol}, 0.06$ eq.), and acetone $/ \mathrm{H}_{2} \mathrm{O}(0.2 \mathrm{~mL}$, 95:5 v/v). Purification by silica gel chromatography (3:1 hexanes:EtOAc) yielded 14 as a white solid (30 mg, $0.060 \mathrm{mmol}, 60 \%$ yield). [ $\mathrm{R}_{\mathrm{f}}=0.2\left(3: 1\right.$ hexanes:EtOAc)]; $[\alpha]_{\mathrm{D}}{ }^{25}=-$ $12.06^{\circ}$ (1.0, $\mathrm{CHCl}_{3}$ ); IR (thin film): 3543, 3068, 2970, 2928, 1641, 1584, 1447, 1378, 1326, 1310, 1144, 1078, 999, 925, 758, 737, 689, 669, 605, 574, 561, $501 \mathrm{~cm}^{-1}$; ${ }^{1} \mathrm{H}-\mathrm{NMR}$ (400 MHz; Benzene): $\delta$ 8.17-8.10 $(\mathrm{m}, 4 \mathrm{H}), 6.94-6.92(\mathrm{~m}, 4 \mathrm{H}), 5.50(\mathrm{dt}, J=16.8,8.9 \mathrm{~Hz}, 1 \mathrm{H}), 5.05(\mathrm{t}, J=6.9 \mathrm{~Hz}, 1 \mathrm{H}), 4.81-4.71(\mathrm{~m}, 2 \mathrm{H}), 2.88-$ $2.76(\mathrm{~m}, 3 \mathrm{H}), 2.55-2.48(\mathrm{~m}, 1 \mathrm{H}), 2.19-2.12(\mathrm{~m}, 1 \mathrm{H}), 2.05-1.93(\mathrm{~m}, 2 \mathrm{H}), 1.61(\mathrm{~s}, 3 \mathrm{H}), 1.51(\mathrm{~s}, 3 \mathrm{H}), 1.41-1.18$ (m, 3H), 0.98 (s, 3H); ${ }^{13} \mathrm{C}-\mathrm{NMR}$ (101 MHz, Benzene): $\delta$ 141.25, 137.24, 137.16, 134.03, 131.78, 131.68, 131.33, 128.50, 124.76, 116.05, 90.94, 72.82, 54.10, 45.72, 41.52, 39.94, 34.25, 25.71, 25.16, 22.67, 17.60; [Chiracel ${ }^{\circledR}$ AD column, eluting with $90: 10$ heptane/IPA, $0.8 \mathrm{~mL} / \mathrm{min}, 254 \mathrm{~nm}$; $\mathrm{t}_{\mathrm{r}}=82.1$ and 88.1 $\min$, 99:1 e.r.]; HR-MS (m/z): [M + Na+] calcd for $\mathrm{C}_{27} \mathrm{H}_{34} \mathrm{NaO}_{5} \mathrm{~S}_{2}$ : 525.1746; found: 525.1746 .

\section{(S)-2-((1R,2S)-4,4-bis(phenylsulfonyl)-2-vinylcyclopentyl)-6-methylhept-5-en-2-ol (16)}

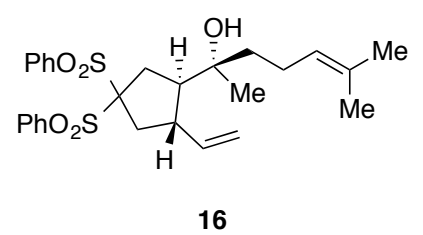

General procedure A was followed with allylic chloride 15 (52 mg, 0.1 mmol, 1 eq.), $\mathrm{NaHCO}_{3}$ (8.4 mg, $0.1 \mathrm{mmol}, 1$ eq.), $\mathrm{CpRu}(\mathrm{MeCN})_{3} \mathrm{PF}_{6}(2.2 \mathrm{mg}$, $0.005 \mathrm{mmol}, 0.05$ eq.), 4 j (5.7 mg, $0.006 \mathrm{mmol}, 0.06$ eq.), and acetone $/ \mathrm{H}_{2} \mathrm{O}$

$(0.2 \mathrm{~mL}, 95: 5 \mathrm{v} / \mathrm{v})$. Purification by silica gel chromatography $(3: 1$ hexanes:EtOAc) yielded 16 as a yellow oil (28 mg, $0.056 \mathrm{mmol}, 56 \%$ yield). [ $\mathrm{R}_{\mathrm{f}}=0.2$ (3:1 hexanes:EtOAc)]; $[\alpha]_{\mathrm{D}} 25=-12.23^{\circ}\left(1.0, \mathrm{CHCl}_{3}\right)$; IR (thin film): 3549, 3069, 2970, 1738, 1583, 1447, 1377, 1327, 1310, 1217, 1144, 1078, 999, 925, 758, 736, 689, 669, 606, 574, 561, $502 \mathrm{~cm}^{-1}$; ${ }^{1} \mathrm{H}-\mathrm{NMR}$ (400 MHz; Benzene): $\delta$ 8.20-8.04 (m, 4H), 6.96-6.93 (m, 4H), 5.60-5.52 (m, 1H), $5.08(\mathrm{t}, J=6.7 \mathrm{~Hz}, 1 \mathrm{H}), 4.79(\mathrm{~d}, J=$ $17.2 \mathrm{~Hz}, 1 \mathrm{H}), 4.71(\mathrm{~d}, J=10.1 \mathrm{~Hz}, 1 \mathrm{H}), 2.87-2.62(\mathrm{~m}, 3 \mathrm{H}), 2.50(\mathrm{t}, J=13.9 \mathrm{~Hz}, 1 \mathrm{H}), 2.21-1.98(\mathrm{~m}, 3 \mathrm{H}), 1.61$ $(\mathrm{s}, 3 \mathrm{H}), 1.54-1.50(\mathrm{~m}, 4 \mathrm{H}), 1.35(\mathrm{t}, J=7.7 \mathrm{~Hz}, 2 \mathrm{H}), 0.94(\mathrm{~s}, 3 \mathrm{H}) ;{ }^{13} \mathrm{C}-\mathrm{NMR}(101 \mathrm{MHz}$, Benzene): $\delta 141.05$, $137.16,137.09,134.12$, 134.09, 131.75, 131.67, 128.55, 124.85, 116.16, 90.97, 73.06, 54.06, 45.70, 41.19, 
39.56, 34.62, 25.75, 24.61, 22.35, 17.64; [Chiracel ${ }^{\circledR} \mathrm{AD}$ column, eluting with 70:30 heptane/IPA, 0.8 $\mathrm{mL} / \mathrm{min}, 254 \mathrm{~nm}$; $\mathrm{t}_{\mathrm{r}}=32.7$ and $59.1 \mathrm{~min}, 96: 4$ e.r.]; HR-MS (m/z): $\left[\mathrm{M}+\mathrm{Na}^{+}\right]$calcd for $\mathrm{C}_{27} \mathrm{H}_{34} \mathrm{NaO}_{5} \mathrm{~S}_{2}$ : 525.1746; found: 525.1746 .

\section{(S)-((3S,4R)-1-(tert-butylsulfonyl)-3-vinylpiperidin-4-yl)(phenyl)methanol (18)}

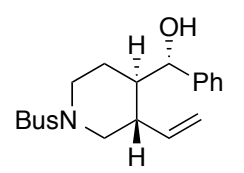

18 General procedure A was followed with allylic chloride 17 (36 mg, $0.1 \mathrm{mmol}, 1$ eq.), $\mathrm{NaHCO}_{3}$ (8.4 mg, 0.1 mmol, 1 eq.), $\mathrm{CpRu}(\mathrm{MeCN})_{3} \mathrm{PF}_{6}$ (2.2 mg, $0.005 \mathrm{mmol}, 0.05$ eq.), 4j (5.7 mg, $0.006 \mathrm{mmol}, 0.06$ eq.), and acetone $(0.2 \mathrm{~mL})$. Purification by silica gel chromatography (4:1 hexanes:EtOAc), and then a second column (30:1 DCM:Et $\mathrm{E}_{2} \mathrm{O}$ yielded 18 as a white solid (17 mg, $0.050 \mathrm{mmol}, 50 \%$ yield). [ $\mathrm{R}_{\mathrm{f}}=0.31$ (3:1 hexanes:EtOAc)]; $[\alpha]_{\mathrm{D}}{ }^{25}=-$ $30.63^{\circ}$ (1.0, $\mathrm{CHCl}_{3}$ ); IR (thin film): 3513, 2987, 2928, 2857, 1641, 1480, 1452, 1395, 1364, 1310, 1190, 1117, 1030, 991, 968, 950, 934, 871, 813, 762, 749, 704, 669, 621, 568, $511 \mathrm{~cm}^{-1}$; ${ }^{1} \mathrm{H}-\mathrm{NMR}(400 \mathrm{MHz}$; $\left.\mathrm{CDCl}_{3}\right): \delta 7.36-7.23(\mathrm{~m}, 5 \mathrm{H}), 5.68(\mathrm{dt}, J=17.2,10.7 \mathrm{~Hz}, 1 \mathrm{H}), 5.32(\mathrm{~d}, J=17.2 \mathrm{~Hz}, 1 \mathrm{H}), 5.25(\mathrm{~d}, J=10.7 \mathrm{~Hz}$, 1H), 5.01 (s, 1H), 3.78 (d, $J=11.9 \mathrm{~Hz}, 2 \mathrm{H}), 2.72$ (q, $J=12.2 \mathrm{~Hz}, 2 \mathrm{H}), 2.55$ (q, $J=8.9 \mathrm{~Hz}, 1 \mathrm{H}), 1.76-1.57(\mathrm{~m}$, 2H), $1.47(\mathrm{t}, J=11.6 \mathrm{~Hz}, 1 \mathrm{H}), 1.31-1.18(\mathrm{~m}, 9 \mathrm{H}) ;{ }^{13} \mathrm{C}-\mathrm{NMR}\left(101 \mathrm{MHz}, \mathrm{CDCl}_{3}\right): \delta 143.43,137.98,128.43$, 127.29, 125.82, 118.77, 72.48, 61.45, 52.48, 47.85, 47.50, 44.05, 24.72, 23.33; [Chiracel® IC column, eluting with 80:20 heptane/IPA, $0.8 \mathrm{~mL} / \mathrm{min}, 220 \mathrm{~nm}$; $\mathrm{t}_{\mathrm{r}}=20.0$ and $21.1 \mathrm{~min}$, $93: 7$ e.r.]; HR-MS (m/z): [M $\left.+\mathrm{Na}^{+}\right]$calcd for $\mathrm{C}_{18} \mathrm{H}_{27} \mathrm{NNaO}_{3} \mathrm{~S}$ : 360.1610 ; found: 360.1609 .

\section{Product Derivitizations}

\section{(3aS,4S,8aS)-2-(tert-butylsulfonyl)-4-phenyl-2,3,3a,4,6,8a-hexahydro-1H-oxepino[3,4-c]pyrrole} (19)

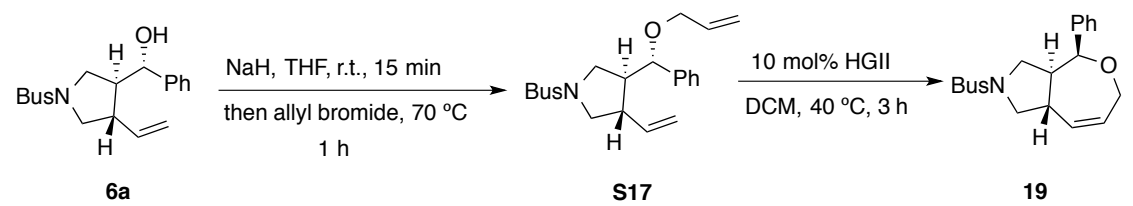

An oven-dried microwave vial with stir bar was charged with $\mathbf{6 a}(40 \mathrm{mg}, 0.12 \mathrm{mmol}, 1$ eq.) and placed under argon. $1.2 \mathrm{~mL}$ of THF was added via syringe followed by sodium hydride (60 wt $\%$ in mineral oil, $9.6 \mathrm{mg}, 0.24 \mathrm{mmol}, 2$ eq.). The reaction was stirred for 15 minutes before allyl bromide was added via syringe $(0.03 \mathrm{~mL}, 0.36 \mathrm{mmol}, 3 \mathrm{eq}$.) and the reaction was heated to 70 degrees in a pre heated oil bath for 1 hour. After 1 hour, the reaction was cooled to room temperature, quenched with $2 \mathrm{~mL}$ saturated aqueous ammonium chloride, extracted with ether ( $3 \times 5 \mathrm{~mL})$, dried over magnesium sulfate, filtered, and concentrated. Purified via silica gel chromatography (9:1 hexanes:EtOAc) to give $(3 S, 4 S)-3-$ ((S)-(allyloxy)(phenyl)methyl)-1-(tert-butylsulfonyl)-4-vinylpyrrolidine $\mathbf{S 1 7}$ as a white solid (37 $\mathrm{mg}, 0.1$ mmol, 83\% yield). $\left[\mathrm{R}_{\mathrm{f}}=0.55\right.$ (3:1 hexanes:EtOAc]; $[\alpha]_{\mathrm{D}}{ }^{25}=-35.32^{\circ}$ (1.0, $\mathrm{CHCl}_{3}$ ); IR (thin film): 3080, 2926, 1644, 1479, 1454, 1425, 1394, 1364, 1313, 1196, 1128, 1065, 1018, 920, 814, 760, 703, 671, 627, 581, $513 \mathrm{~cm}^{-1} ;{ }^{1} \mathrm{H}-\mathrm{NMR}\left(400 \mathrm{MHz} ; \mathrm{CDCl}_{3}\right): \delta 7.34-7.22(\mathrm{~m}, 5 \mathrm{H}), 5.88(\mathrm{ddt}, J=16.8,11.0,5.6 \mathrm{~Hz}, 1 \mathrm{H}), 5.49(\mathrm{dt}, J$ $=17.8,8.9 \mathrm{~Hz}, 1 \mathrm{H}), 5.22(\mathrm{~d}, J=17.8 \mathrm{~Hz}, 1 \mathrm{H}), 5.15(\mathrm{~d}, J=9.9 \mathrm{~Hz}, 1 \mathrm{H}), 4.98-4.94(\mathrm{~m}, 2 \mathrm{H}), 4.30(\mathrm{~d}, J=5.1 \mathrm{~Hz}$, 
1H), $3.94(\mathrm{dd}, J=12.6,4.8 \mathrm{~Hz}, 1 \mathrm{H}), 3.76-3.65(\mathrm{~m}, 3 \mathrm{H}), 3.44(\mathrm{t}, J=8.7 \mathrm{~Hz}, 1 \mathrm{H}), 3.22(\mathrm{t}, J=9.4 \mathrm{~Hz}, 1 \mathrm{H}), 2.82$ (quintet, $J=8.5 \mathrm{~Hz}, 1 \mathrm{H}), 2.25$ (qd, $J=8.2,5.4 \mathrm{~Hz}, 1 \mathrm{H}), 1.37(\mathrm{~s}, 8 \mathrm{H}) ;{ }^{13} \mathrm{C}-\mathrm{NMR}\left(101 \mathrm{MHz}, \mathrm{CDCl}_{3}\right): \delta 140.60$, 137.19, 134.85, 128.76, 128.07, 126.94, 117.35, 117.26, 79.62, 69.99, 61.43, 54.58, 52.06, 50.60, 45.58, 24.75; HR-MS (m/z): [M + Na+] calcd for $\mathrm{C}_{20} \mathrm{H}_{29} \mathrm{NNaO}_{3} \mathrm{~S}$ : 386.1766; found: 386.1766 .

An oven-dried microwave vial with stir bar was charged with $\mathbf{S 1 7}$ (18 mg, $0.05 \mathrm{mmol}, 1$ eq.) and placed under argon. $4 \mathrm{~mL}$ of DCM was added via syringe. In a separate oven dried vial was charged 10 mol\% of Hoveyda-Grubbs Second Generation Catalyst (3 mg, $0.005 \mathrm{mmol}, 0.1$ eq.) and placed under argon. The catalyst was dissolved in $1 \mathrm{~mL}$ DCM and added to the solution containing S17. The reaction was heated to 40 degrees for 3 hours before being cooled to room temperature and quenched with $1 \mathrm{~mL}$ of ethyl vinyl ether. The solution was stirred for 30 minutes before being passed through a plug of neutral alumina (ether as an eluent). The solution was concentrated in vacuo and purified via silica gel chromatography (9:1 hexanes:EtOAc) to give (3aS,4S,8aS)-2-(tert-butylsulfonyl)-4-phenyl-2,3,3a,4,6,8ahexahydro-1H-oxepino[3,4-c]pyrrole 19 as a clear film (14 mg, $0.042 \mathrm{mmol}, 84 \%$ yield). [ $\mathrm{R}_{\mathrm{f}}=0.3$ (3:1 hexanes:EtOAc)]; $[\alpha]_{\mathrm{D}}{ }^{25}==+48.30^{\circ}\left(1.0, \mathrm{CHCl}_{3}\right)$; IR (thin film): 2931, 1737, 1479, 1453, 1393, 1364, 1312, 1210, 1122, 1078, 1030, 964, 919, 890, 817, 778, 750, 708, 681, 664, 625, 579, $513 \mathrm{~cm}^{-1}$; ${ }^{1} \mathrm{H}-\mathrm{NMR}$ (400 MHz; $\left.\mathrm{CDCl}_{3}\right): \delta$ 7.34-7.26 (m, 5H), $5.78(\mathrm{ddt} J=10.8,4.8,2.5 \mathrm{~Hz}, 1 \mathrm{H}), 5.62(\mathrm{~d}, J=10.8 \mathrm{~Hz}, 1 \mathrm{H}), 4.96$ (d, $J=7.4 \mathrm{~Hz}, 1 \mathrm{H}), 4.49-4.38(\mathrm{~m}, 2 \mathrm{H}), 3.66(\mathrm{t}, J=8.9 \mathrm{~Hz}, 1 \mathrm{H}), 3.56(\mathrm{t}, J=8.9 \mathrm{~Hz}, 1 \mathrm{H}), 3.36-3.27(\mathrm{~m}, 1 \mathrm{H})$, $3.19(\mathrm{t}, J=9.9 \mathrm{~Hz}, 1 \mathrm{H}), 3.02(\mathrm{tt}, J=10.9,7.7 \mathrm{~Hz}, 1 \mathrm{H}), 2.50(\mathrm{t}, J=10.2 \mathrm{~Hz}, 1 \mathrm{H}), 1.21(\mathrm{~s}, 9 \mathrm{H}) ;{ }^{13} \mathrm{C}-\mathrm{NMR}(101$ $\left.\mathrm{MHz}, \mathrm{CDCl}_{3}\right): \delta$ 139.12, 130.91, 130.09, 128.68, 128.33, 127.09, 80.19, 67.63, 61.43, 54.56, 52.36, 48.67, 39.00, 24.54; HR-MS (m/z): [M + Na+] calcd for $\mathrm{C}_{18} \mathrm{H}_{25} \mathrm{NNaO}_{3} \mathrm{~S}$ : 358.1453; found: 358.1453 .

\section{Key NOE Spin Polarization Transfers for 19 (See below for spectra and 2D COSY)}

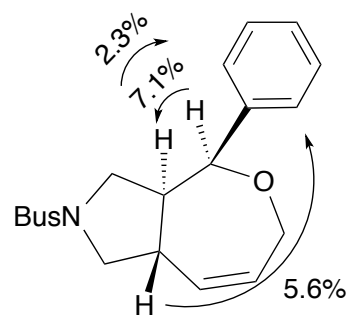




\section{(3S,4S)-3-((S)-(4-methoxyphenyl)(phenyl)methyl)-4-vinylpyrrolidine (20)}

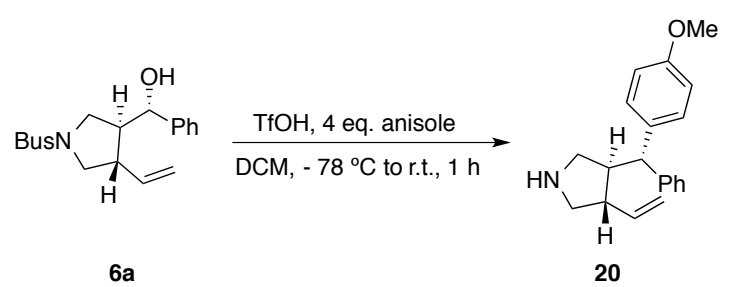

A mixture of 6 a (20 mg $0.06 \mathrm{mmol}, 1$ eq.) and anhydrous anisole $(0.026 \mathrm{~mL}, 0.24 \mathrm{mmol}, 4 \mathrm{eq}$. was added to an oven-dried microwave vial, placed under argon, and dissolved in $0.6 \mathrm{~mL}$ of DCM. The mixture was cooled to -78 degrees in a dry ice/acetone bath and a $0.3 \mathrm{M}$ solution of triflic acid in DCM (1.2 $\mathrm{mL}, 0.36 \mathrm{mmol}, 3$ eq.) was added dropwise via syringe. The reaction was warmed to room temperature and stirred for 1 hour. The reaction was quenched with pH 7 buffer $(5 \mathrm{~mL})$ and the layers were separated. The aqueous phase was extracted with DCM $(5 \mathrm{~mL})$ and the combined organics were washed with brine ( $5 \mathrm{~mL}$ ), dried over sodium sulfate, filtered, and concentrated. Purified via silica gel chromatography (9:1:0.6 DCM:MeOH:7 $\mathrm{N}$ ammonia in methanol) gave $(3 S, 4 S)-3-((S)-(4-$ methoxyphenyl)(phenyl)methyl)-4-vinylpyrrolidine 20 as a foamy off-white solid (16 mg, >20:1 d.r., $0.054 \mathrm{mmol}, 91 \%$ yield) containing $10 \%$ of its ortho regioisomer. $\left[\mathrm{R}_{\mathrm{f}}=0.2(7: 1\right.$ toluene:3 N NH 3 in EtOH)]; $[\alpha]_{\mathrm{D}^{25}}==+15.81^{\circ}\left(1.0, \mathrm{CHCl}_{3}\right)$; IR (thin film): 3026, 2929, 2835, 1638, 1609, 1583, 1509, 1494, $1453,1441,1420,1301,1246,1178,1113,1029,992,910,804,783,727,699,661,638,618,568 \mathrm{~cm}^{-1}$; ${ }^{1} \mathrm{H}-\mathrm{NMR}\left(400 \mathrm{MHz} ; \mathrm{CDCl}_{3}\right.$ ): $\delta$ 7.31-7.11 (m, 7H), $6.79(\mathrm{~d}, J=8.6 \mathrm{~Hz}, 2 \mathrm{H}), 5.45$ (ddd, $J=17.2,10.1,7.9 \mathrm{~Hz}$, 1H), $4.72(\mathrm{~d}, J=10.1 \mathrm{~Hz}, 1 \mathrm{H}), 4.61(\mathrm{~d}, J=17.2 \mathrm{~Hz}, 1 \mathrm{H}), 4.55(\mathrm{br} \mathrm{s}, 1 \mathrm{H}), 3.80$ (d, $J=10.8 \mathrm{~Hz}, 1 \mathrm{H}), 3.74(\mathrm{~s}$, $3 \mathrm{H}), 3.29-3.18(\mathrm{~m}, 2 \mathrm{H}), 2.92-2.70(\mathrm{~m}, 3 \mathrm{H}), 2.56(\mathrm{dq}, J=13.9,6.9 \mathrm{~Hz}, 1 \mathrm{H}) ;{ }^{13} \mathrm{C}-\mathrm{NMR}\left(101 \mathrm{MHz}, \mathrm{CDCl}_{3}\right): \delta$ 158.38, 143.66, 138.67, 135.74, 129.15, 128.63, 128.42, 126.67, 115.30, 114.28, 55.43, 55.03, 51.64, 50.99, 48.99, 47.96; HR-MS (m/z): [M + $\left.\mathrm{H}^{+}\right]$calcd for $\mathrm{C}_{20} \mathrm{H}_{24} \mathrm{NO}$ : 294.1858; found: 294.1858 .

\section{3-((S)-phenyl((3S,4S)-4-vinylpyrrolidin-3-yl)methyl)-1-tosyl-1H-indole (21)}

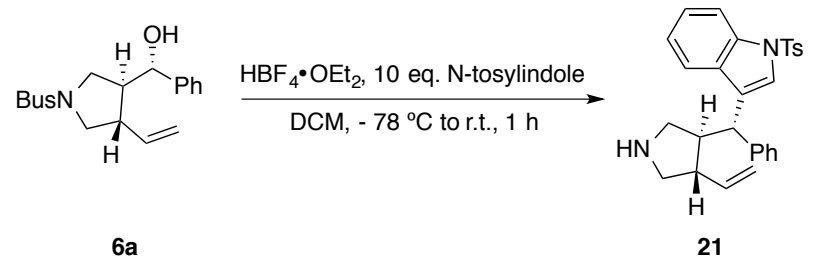

A mixture of 6 a (20 mg $0.06 \mathrm{mmol}, 1$ eq.) and $\mathrm{N}$-tosylindole (163 mg, $0.6 \mathrm{mmol}, 10$ eq.) was added to an oven-dried microwave vial, placed under argon, and dissolved in $0.6 \mathrm{~mL}$ of DCM. The mixture was cooled to -78 degrees in a dry ice/acetone bath and $\mathrm{HBF}_{4} \cdot \mathrm{OEt}_{2}(0.024 \mathrm{~mL}, 0.18 \mathrm{mmol}, 3$ eq. $)$ was added dropwise via syringe. The reaction was warmed to room temperature and stirred for 1 hour. The reaction was quenched with $2 \mathrm{~N} \mathrm{NaOH}(1 \mathrm{~mL})$ and the layers were separated. The aqueous phase was extracted with DCM $(1 \mathrm{~mL})$ and the combined organics were washed with brine $(2 \mathrm{~mL})$, dried over sodium sulfate, filtered, and concentrated. Purified via silica gel chromatography (20:1 DCM:7 N 
ammonia in methanol) gave 3-((S)-phenyl((3S,4S)-4-vinylpyrrolidin-3-yl)methyl)-1-tosyl-1H-indole 21 as a sticky pinkish solid (26 mg, 10:1 d.r., $0.057 \mathrm{mmol}, 95 \%$ yield). $\left[\mathrm{R}_{\mathrm{f}}=0.24\right.$ 7:1 toluene:3N $\mathrm{NH}_{3}$ in EtOH]; $[\alpha]_{\mathrm{D}}{ }^{25}==+15.41^{\circ}\left(1.0, \mathrm{CHCl}_{3}\right)$; IR (thin film): 3063, 3027, 2957, 2926, 2871, 1722, 1639, 1598, $1494,1448,1366,1280,1208,1187,1173,1132,1121,1091,1021,973,911,813,746,703,677,628$, 617, 579, $538 \mathrm{~cm}^{-1} ;{ }^{1} \mathrm{H}-\mathrm{NMR}\left(400 \mathrm{MHz} ; \mathrm{CDCl}_{3}\right): \delta 7.91(\mathrm{~d}, J=8.3 \mathrm{~Hz}, 1 \mathrm{H}), 7.72(\mathrm{~d}, J=8.3 \mathrm{~Hz}, 2 \mathrm{H}), 7.58(\mathrm{~s}$, $1 \mathrm{H}), 7.30$ (d, $J=7.8 \mathrm{~Hz}, 1 \mathrm{H}), 7.24-7.06(\mathrm{~m}, 9 \mathrm{H}), 5.32$ (ddd, $J=17.2,10.1,7.8 \mathrm{~Hz}, 1 \mathrm{H}), 4.59$ (d, $J=10.1 \mathrm{~Hz}$, 1H), 4.44 (d, $J=17.2 \mathrm{~Hz}, 1 \mathrm{H}$ ), 3.99 (d, $J=10.7 \mathrm{~Hz}, 1 \mathrm{H}$ ), 3.40 (dd, $J=11.4,8.0 \mathrm{~Hz}, 1 \mathrm{H}$ ), 3.24 (dd, $J=11.2,7.5$ $\mathrm{Hz}, 1 \mathrm{H}), 2.89-2.76(\mathrm{~m}, 3 \mathrm{H}), 2.56(\mathrm{dt}, J=14.9,7.4 \mathrm{~Hz}, 1 \mathrm{H}), 2.30(\mathrm{~s}, 3 \mathrm{H}) ;{ }^{13} \mathrm{C}-\mathrm{NMR}\left(101 \mathrm{MHz}, \mathrm{CDCl}_{3}\right): \delta$ 145.19, 141.58, 138.69, 135.09, 130.10, 128.78, 128.56, 127.05, 126.91, 126.00, 125.10, 123.48, 122.82, 120.24, 114.83, 113.96, 52.88, 52.62, 49.36, 48.15, 47.35, 21.77; HR-MS (m/z): [M + $\left.\mathrm{H}^{+}\right]$calcd for $\mathrm{C}_{28} \mathrm{H}_{29} \mathrm{~N}_{2} \mathrm{O}_{2} \mathrm{~S}: 457.1949$; found: 457.1950 .

\section{$(3 S, 4 S)-3-((S)$-benzo[b]thiophen-3-yl(phenyl)methyl)-4-vinylpyrrolidine (22)}

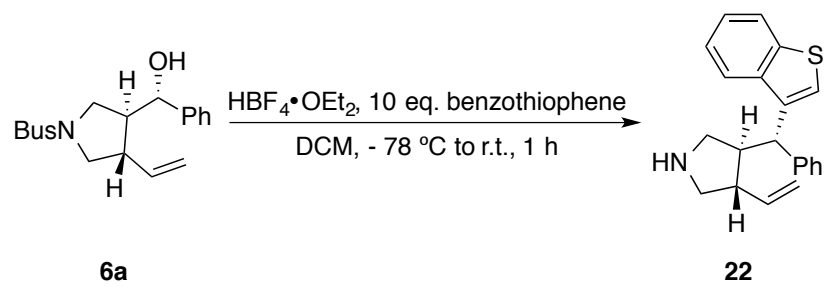

A mixture of $6 \mathbf{a}$ (20 mg $0.06 \mathrm{mmol}, 1 \mathrm{eq}$ ) and benzo[b]thiophene (81 $\mathrm{mg}, 0.6 \mathrm{mmol}, 10 \mathrm{eq}$.) was added to an oven-dried microwave vial, placed under argon, and dissolved in $0.6 \mathrm{~mL}$ of DCM. The mixture was cooled to -78 degrees in a dry ice/acetone bath and $\mathrm{HBF}_{4} \cdot \mathrm{OEt}_{2}(0.024 \mathrm{~mL}, 0.18 \mathrm{mmol}, 3 \mathrm{eq}$.) was added dropwise via syringe. The reaction was warmed to room temperature and stirred for 1 hour. The reaction was quenched with $2 \mathrm{~N} \mathrm{NaOH}(1 \mathrm{~mL})$ and the layers were separated. The aqueous phase was extracted with DCM $(1 \mathrm{~mL})$ and the combined organics were washed with brine $(2 \mathrm{~mL})$, dried over sodium sulfate, filtered, and concentrated. Purified via silica gel chromatography (20:1 DCM:7 N ammonia in methanol) gave 3-((S)-phenyl((3S,4S)-4-vinylpyrrolidin-3-yl)methyl)-1-tosyl-1H-indole 22 as a sticky off-white solid (16 mg, 8:1 d.r., $0.050 \mathrm{mmol}, 83 \%$ yield). [ $\mathrm{R}_{\mathrm{f}}=0.2$ 7:1 toluene:3N NH 3 in EtOH]; $[\alpha]_{\mathrm{D}}{ }^{25}==+8.68^{\circ}\left(1.0, \mathrm{CHCl}_{3}\right)$; IR (thin film): 3061, 3025, 2917, 2849, 2755, 1659, 1601, 1495, 1454, 1426, 1386, 1329, 1262, 1156, 1079, 1022, 988, 912, 755, 730, 701, 687, 669, 656, 649, 625, 617, 554, $527 \mathrm{~cm}^{-1} ;{ }^{1} \mathrm{H}-\mathrm{NMR}\left(400 \mathrm{MHz} ; \mathrm{CDCl}_{3}\right): \delta$ 7.82-7.78 (m, $\left.1 \mathrm{H}\right), 7.72-7.64(\mathrm{~m}, 1 \mathrm{H}), 7.36(\mathrm{~s}, 1 \mathrm{H}), 7.32-7.27(\mathrm{~m}$, $3 \mathrm{H}), 7.25-7.10(\mathrm{~m}, 4 \mathrm{H}), 5.40(\mathrm{dt}, J=17.3,8.8 \mathrm{~Hz}, 1 \mathrm{H}), 4.57(\mathrm{~d}, J=10.0 \mathrm{~Hz}, 1 \mathrm{H}), 4.41(\mathrm{~d}, J=17.3 \mathrm{~Hz}, 1 \mathrm{H})$, $4.17(\mathrm{~d}, J=10.8 \mathrm{~Hz}, 1 \mathrm{H}), 3.32-3.26(\mathrm{~m}, 1 \mathrm{H}), 3.16(\mathrm{dd}, J=11.0,7.3 \mathrm{~Hz}, 1 \mathrm{H}), 2.79-2.70(\mathrm{~m}, 2 \mathrm{H}), 2.54$ (quintet, $J=7.6 \mathrm{~Hz}, 2 \mathrm{H}) ;{ }^{13} \mathrm{C}-\mathrm{NMR}\left(101 \mathrm{MHz}, \mathrm{CDCl}_{3}\right): \delta 142.34,142.28,140.53,140.46,128.92,128.65$, $128.49,126.76,124.50,124.12,122.94,122.39,121.38,113.65,53.85,53.59,50.79$, 50.54, 48.97; HR-MS (m/z): $\left[\mathrm{M}+\mathrm{H}^{+}\right]$calcd for $\mathrm{C}_{21} \mathrm{H}_{22} \mathrm{NS}$ : 320.1473; found: 320.1473 . 


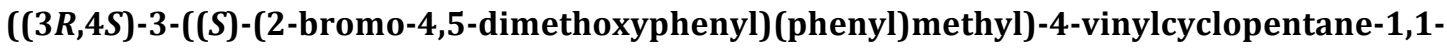
disulfonyl)dibenzene (23)

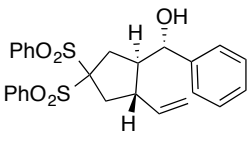

12b

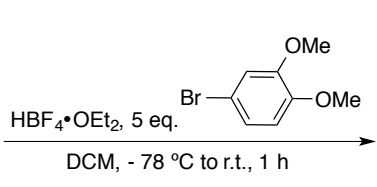

$\mathrm{PhO}_{2} \mathrm{~S}$

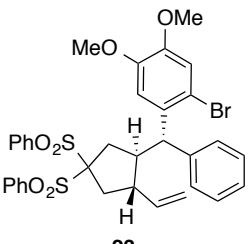

A mixture of $12 \mathbf{b}$ ( $60 \mathrm{mg} 0.12 \mathrm{mmol}, 1$ eq.) was added to an oven-dried microwave vial, placed under argon, and dissolved in $1.2 \mathrm{~mL}$ of DCM. 4-bromoveratrole ( $0.085 \mathrm{~mL}, 0.6 \mathrm{mmol}, 5$ eq.) was added via syringe. The mixture was cooled to -78 degrees in a dry ice/acetone bath and $\mathrm{HBF}_{4} \bullet \mathrm{OEt}_{2}(0.049 \mathrm{~mL}$, $0.36 \mathrm{mmol}, 3 \mathrm{eq}$.) was added dropwise via syringe. The reaction was warmed to room temperature and stirred for 1 hour. The reaction was quenched with $2 \mathrm{~N} \mathrm{NaOH}(2 \mathrm{~mL})$ and the layers were separated. The aqueous phase was extracted with DCM $(2 \mathrm{~mL})$ and the combined organics were washed with brine ( $4 \mathrm{~mL}$ ), dried over magnesium sulfate, filtered, and concentrated. Purified via silica gel chromatography (3:1 hexanes:EtOAc) gave ((3R,4S)-3-((S)-(2-bromo-4,5-dimethoxyphenyl)(phenyl)methyl)-4vinylcyclopentane-1,1-disulfonyl)dibenzene 23 as a white solid (78 mg, 5:1 d.r., 0.11 mmol, 92\% yield). Recrystallization from toluene/hexanes gave material that was $>20: 1$ d.r. $(75 \%$ yield after recrystallization). $\left[\mathrm{R}_{\mathrm{f}}=0.23: 1\right.$ hexanes:EtOAc]; $[\alpha]_{\mathrm{D}}{ }^{25}==+4.31^{\circ}\left(0.5, \mathrm{CHCl}_{3}\right)$; IR (thin film): 3064, 2931, $2843,1602,1583,1503,1447,1377,1325,1310,1262,1247,1211,1143,1078,1027,999,967,911$, 869, 845, 812, 731, 688, 669, 648, 604, 594, 571, $554 \mathrm{~cm}^{-1} ;{ }^{1} \mathrm{H}-\mathrm{NMR}\left(400 \mathrm{MHz} ; \mathrm{CDCl}_{3}\right): \delta 8.04(\mathrm{dd}, J=$ 15.1, 7.7 Hz, 4H), 7.75-7.70 (m, 2H), 7.60 (td, $J=7.7,3.7 \mathrm{~Hz}, 4 \mathrm{H}), 7.24-7.10(\mathrm{~m}, 5 \mathrm{H}), 6.97(\mathrm{~s}, 1 \mathrm{H}), 6.95(\mathrm{~s}$, 1H), $5.06(\mathrm{dt}, J=16.6,9.4 \mathrm{~Hz}, 1 \mathrm{H}), 4.50(\mathrm{~d}, J=16.6 \mathrm{~Hz}, 1 \mathrm{H}), 4.41(\mathrm{~d}, J=9.4 \mathrm{~Hz}, 1 \mathrm{H}), 4.22(\mathrm{~d}, J=10.3 \mathrm{~Hz}$, $1 \mathrm{H}), 3.89$ (s, 3H), $3.83(\mathrm{~s}, 3 \mathrm{H}), 2.97-2.87(\mathrm{~m}, 1 \mathrm{H}), 2.65-2.57(\mathrm{~m}, 2 \mathrm{H}), 2.44-2.27(\mathrm{~m}, 2 \mathrm{H}), 2.17$ (dd, $J=15.5$, $11.4 \mathrm{~Hz}, 1 \mathrm{H}) ;{ }^{13} \mathrm{C}-\mathrm{NMR}\left(101 \mathrm{MHz}, \mathrm{CDCl}_{3}\right): \delta 149.12,148.33,141.88,137.77,136.40,136.04,134.93$, $134.90,134.55,131.75,131.65,129.05,128.95,128.79,128.38,126.94,115.79,115.37,114.76,111.06$, 90.69, 56.50, 56.34, 54.38, 49.99, 49.59, 39.36, 38.72; HR-MS (m/z): [M + Na+] calcd for $\mathrm{C}_{34} \mathrm{H}_{33} \mathrm{BrNaO}_{6} \mathrm{~S}_{2}$ : 703.0800; found: 703.0800 .

$(3 \mathrm{a} R, 9 S, 9 \mathrm{a} R)-6,7-$ dimethoxy-4-methylene-9-phenyl-2,2-bis(phenylsulfonyl)-2,3,3a,4,9,9ahexahydro-1 $H$-cyclopenta[b]naphthalene (24)

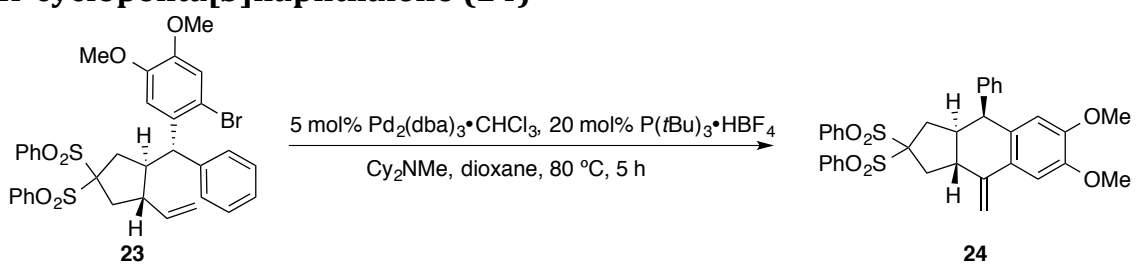

23 (10 mg, $0.014 \mathrm{mmol}, 1$ eq. ), $\mathrm{Pd}_{2} \mathrm{dba}_{3} \cdot \mathrm{CHCl}_{3}(0.7 \mathrm{mg}, 0.0007 \mathrm{mmol}, 0.05$ eq.), and tri-tertbutylphosphonium tetrafluoroborate $(0.8 \mathrm{mg}, 0.0028 \mathrm{mmol}, 0.2 \mathrm{eq}$.$) , were added to an oven-dried$ microwave vial with stir bar and placed under nitrogen. $0.2 \mathrm{~mL}$ of dry, degassed dioxane and distilled $\mathrm{N}$ methyldicyclohexylamine $(0.010 \mathrm{~mL}, 0.042 \mathrm{mmol}, 3$ eq. $)$ were added to the reaction via syringe and was 
heated to 80 degrees for 5 hours. After 5 hours, the reaction was diluted with water $(1 \mathrm{~mL})$, extracted with ether ( $3 \times 2 \mathrm{~mL}$ ), dried over magnesium sulfate, filtered, and concentrated. Purification of the crude residue via silica gel chromatography gave $(3 \mathrm{a} R, 9 S, 9 \mathrm{a} R)-6,7-$ dimethoxy-4-methylene-9-phenyl-2,2bis(phenylsulfonyl)-2,3,3a,4,9,9a-hexahydro- $1 H$-cyclopenta[ $b]$ naphthalene $\mathbf{2 4}$ as a clear film (5 mg, $0.008 \mathrm{mmol}, 57 \%$ yield). [ $\mathrm{R}_{\mathrm{f}}=0.153: 1$ hexanes:EtOAc]; $[\alpha]_{\mathrm{D}^{25}}=++128.58^{\circ}\left(0.3, \mathrm{CHCl}_{3}\right)$; IR (thin film): 3063, 3003, 2932, 2850, 1605, 1583, 1519, 1495, 1464, 1447, 1358, 1327, 1310, 1257, 1217, 1183, 1142, 1110, 1079, 1028, 912, 868, 730, 688, 669, 649, 606, 589, 568, 557, $539 \mathrm{~cm}^{-1}$; ${ }^{1} \mathrm{H}-\mathrm{NMR}$ (400 MHz; $\mathrm{CDCl}_{3}$ ): $\delta 8.13(\mathrm{~d}, J=7.7 \mathrm{~Hz}, 2 \mathrm{H}), 7.72-7.58(\mathrm{~m}, 5 \mathrm{H}), 7.40(\mathrm{t}, J=7.8 \mathrm{~Hz}, 2 \mathrm{H}), 7.30-7.26(\mathrm{~m}, 6 \mathrm{H}), 7.03-7.01$ (m, 2H), 6.69 (s, 1H), $6.54(\mathrm{~s}, 1 \mathrm{H}), 6.33(\mathrm{~d}, J=11.9 \mathrm{~Hz}, 1 \mathrm{H}), 5.56(\mathrm{~d}, J=11.9 \mathrm{~Hz}, 1 \mathrm{H}), 4.11(\mathrm{~d}, J=1.2 \mathrm{~Hz}$, $1 \mathrm{H}), 3.87$ (s, 3H), 3.77 (s, 3H), 2.85-2.69 (m, 2H), 2.57 (dd, J = 14.6, $6.8 \mathrm{~Hz}, 1 \mathrm{H}), 2.43-2.35(\mathrm{~m}, 1 \mathrm{H}), 2.27-$ $2.10(\mathrm{~m}, 2 \mathrm{H}) ;{ }^{13} \mathrm{C}-\mathrm{NMR}\left(101 \mathrm{MHz}, \mathrm{CDCl}_{3}\right): \delta{ }^{13} \mathrm{C}-\mathrm{NMR}\left(101 \mathrm{MHz}, \mathrm{CDCl}_{3}\right): \delta$ 148.14, 147.31, 140.86, $136.77,135.59,134.83,134.65,134.49,131.86,131.34,130.98,129.79,128.90,128.86,128.56,127.71$, $127.58,127.31,116.69,114.67,91.42,56.12,56.03,53.26,44.92,41.90,37.73,36.86 ;$ HR-MS (m/z): [M + $\left.\mathrm{Na}^{+}\right]$calcd for $\mathrm{C}_{34} \mathrm{H}_{32} \mathrm{O}_{6} \mathrm{~S}_{2}: 623.1538$; found: 623.1538 .

${ }^{i}$ Liu, Y.; Zhang, S.; Miao, Q.; Zheng, L.; Zong, L.; Cheng, Y. Macromolecules 2007, 40, 4839-4847. ii Wang, K.-B.; Ran, R.-Q.; Xiu, S.-D.; Li, C.-Y. Org. Lett. 2013, 15, 2374.

iii Zhu, J.; Liu, J.; Ma, R.; Xie, H.; Li, J.; Jiang, H.; Wang, W. Adv. Synth. Catal. 2009, 351, 1229.

iv Reddy, A. G. K.; Mahendar, L.; Satyanarayana, G. Synthetic Communications 2014, 44 (14), 2076.

v Nieto-Oberhuber, C.; Pérez-Galán, P.; Herrero-Gómez, E.; Lauterbach, T.; Rodríguez, C.; López, S.; Bour, C.; Rosellón, A.; Cárdenas, D. J.; Echavarren, A. M. J. Am. Chem. Soc. 2008, 130, 269.

vi Teller, H.; Corbet, M.; Mantilli, L.; Gopakumar, G.; Goddard, R.; Thiel, W.; Fürstner, A. J. Am. Chem. Soc. 2012, 134, 15331.

vii Blanco Jaimes, M. C.; Ahrens, A.; Pflästerer, D.; Rudolph, M.; Hashmi, A. S. K. Chem. Eur. J. 2015, $21,427$. viii Trost, B. M.; Belletire, J. L.; Godleski, S.; McDougal, P. G.; Balkovec, J. M.; Baldwin, J. J.; Christy, M. E.; Ponticello, G. S.; Varga, S. L.; Springer, J. P. J. Org. Chem. 1986, 51, 2370. 


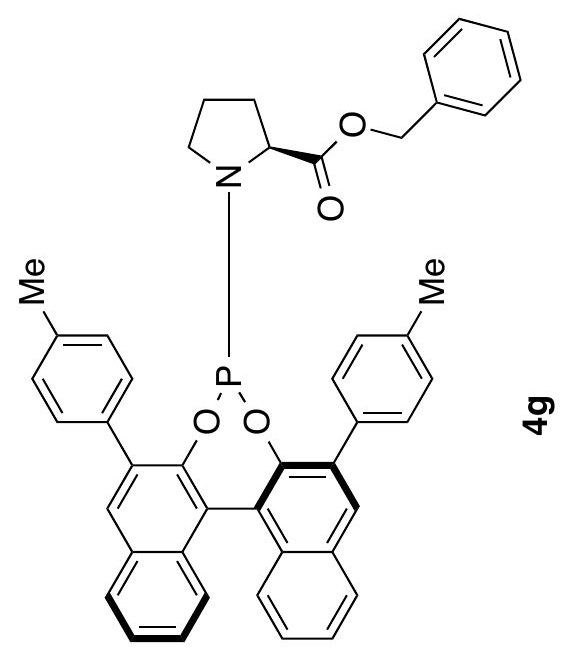




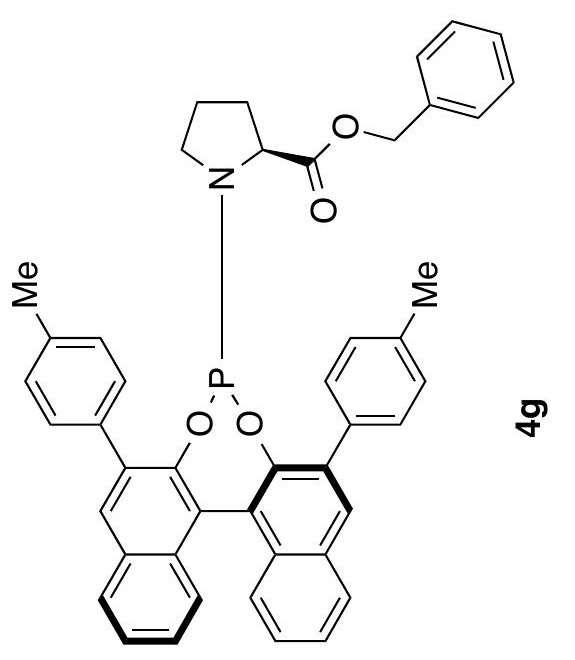




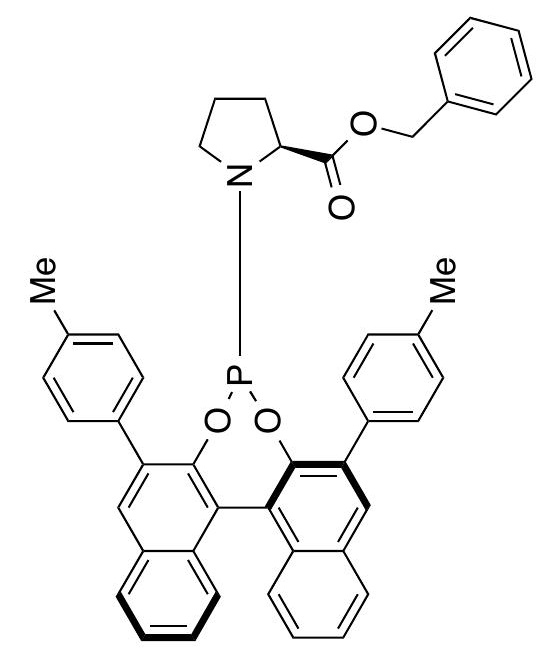




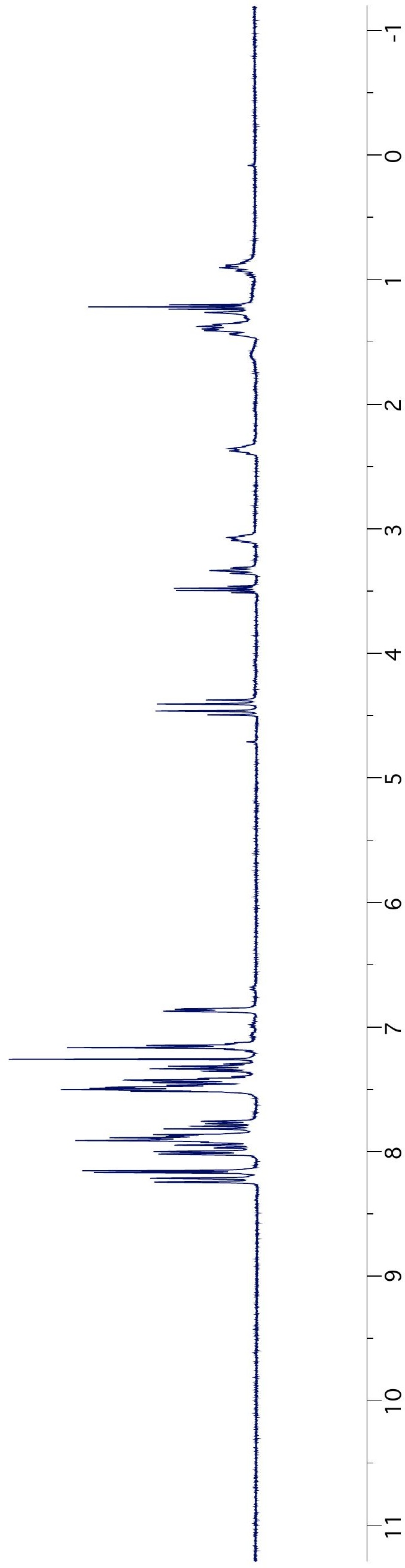




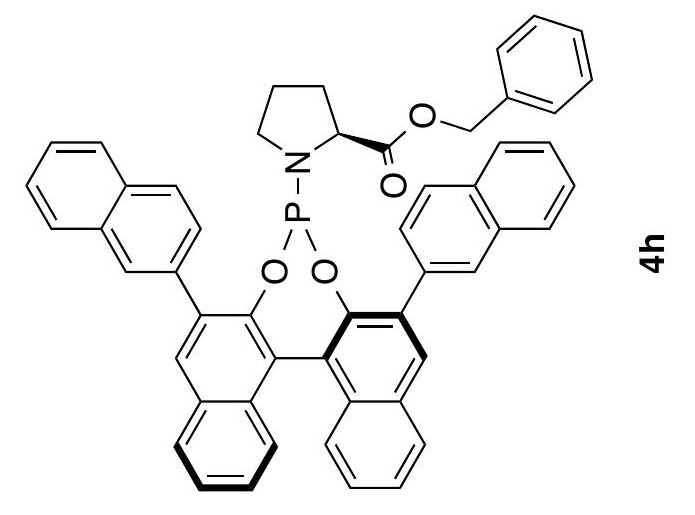




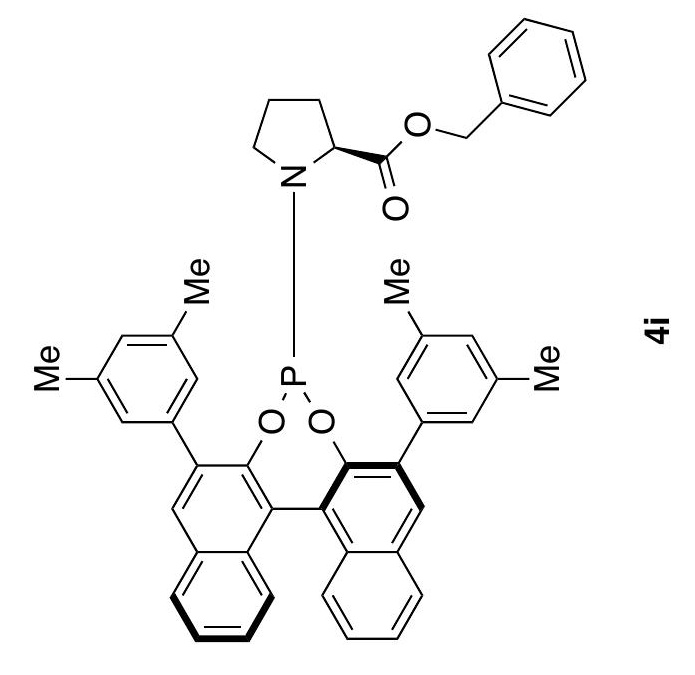




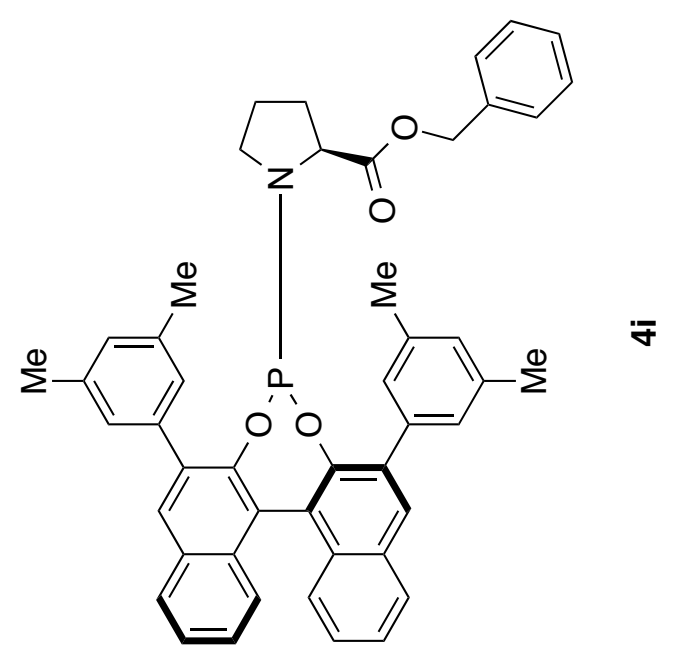




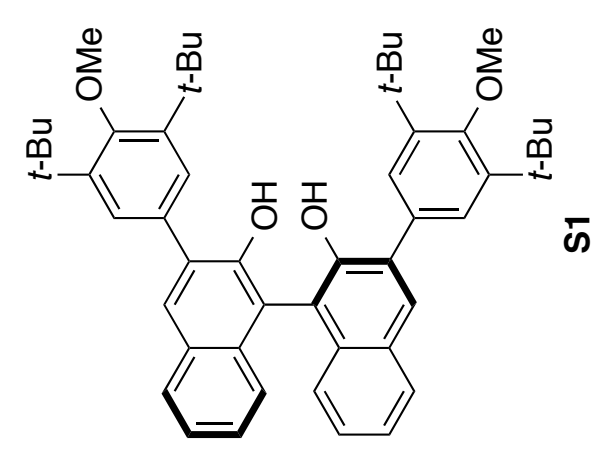




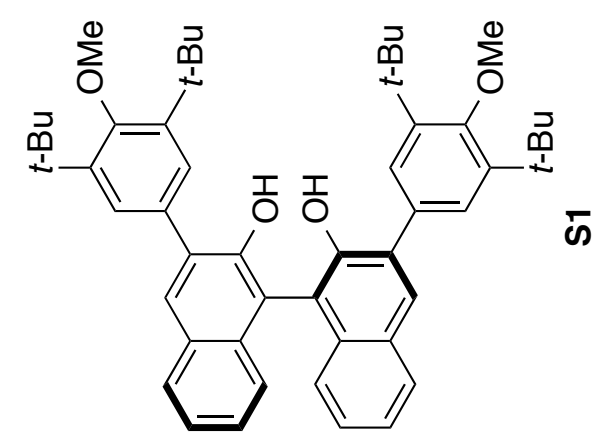




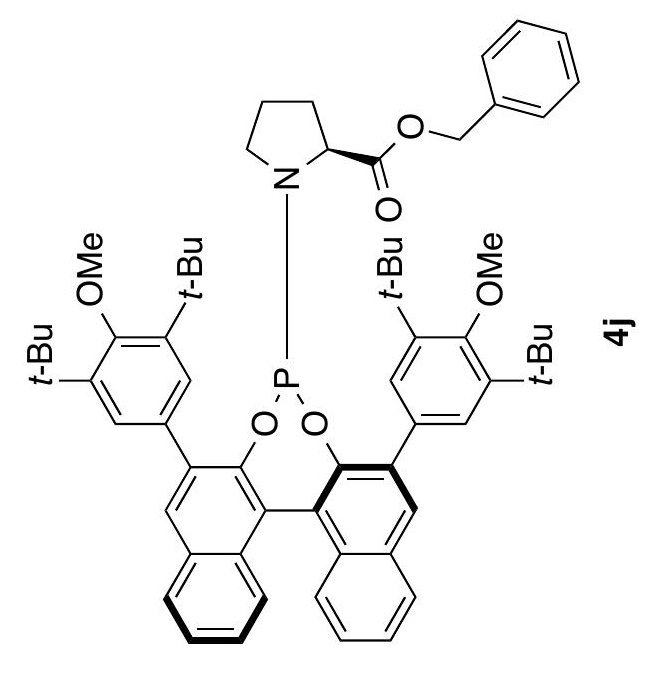




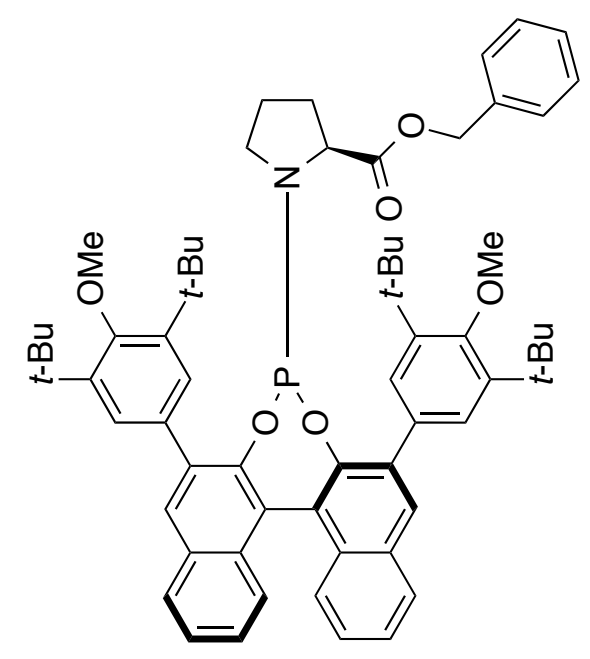







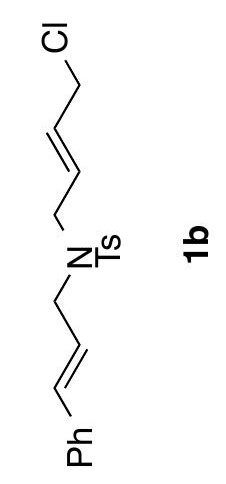

S56 


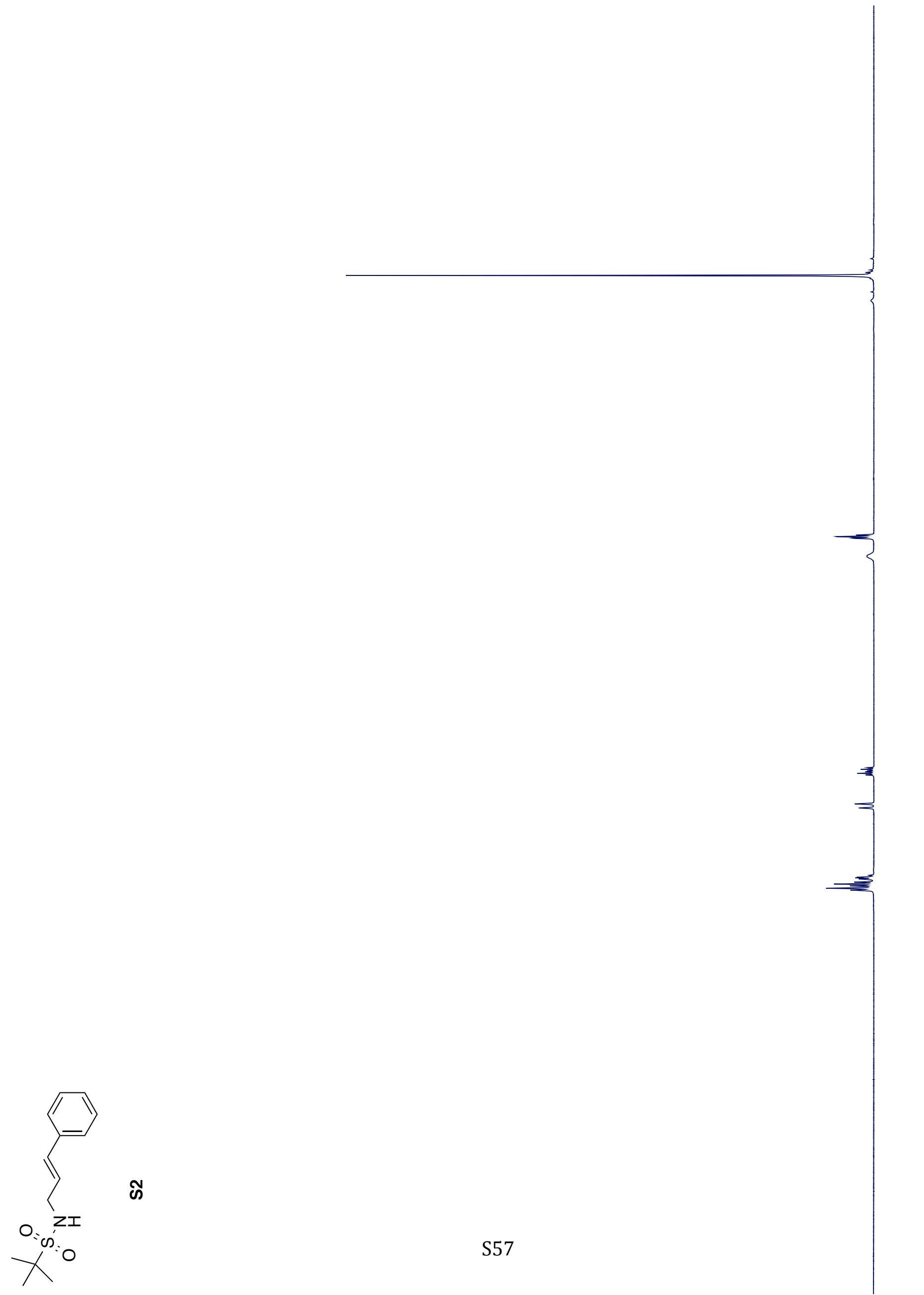




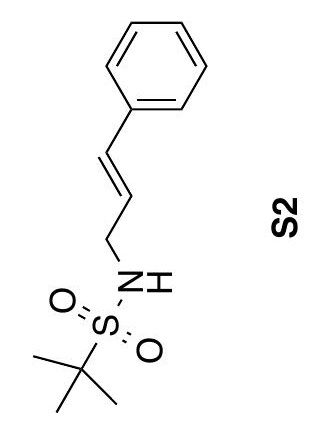





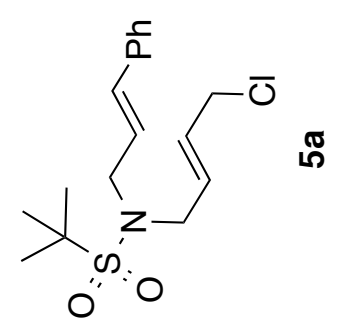




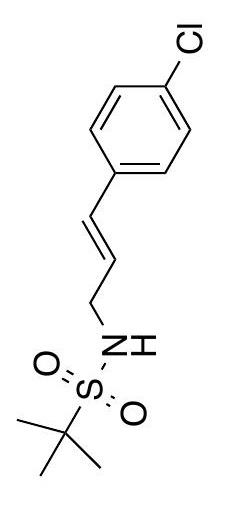

$\mathscr{8}$ 


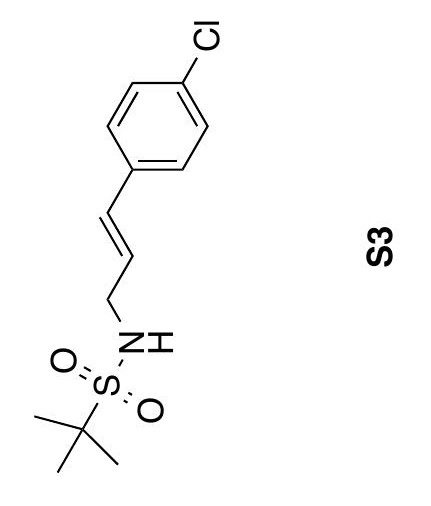




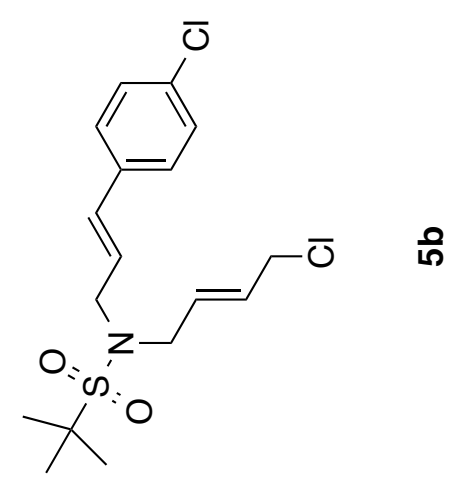




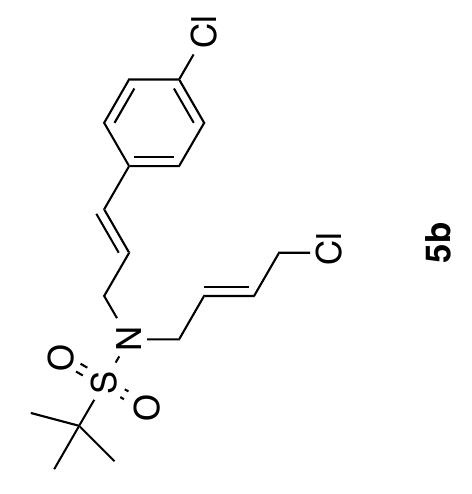





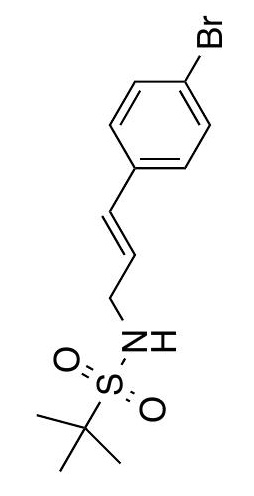

ऊ

S66 


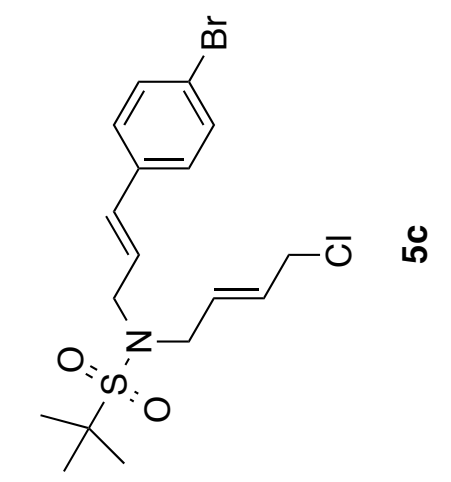




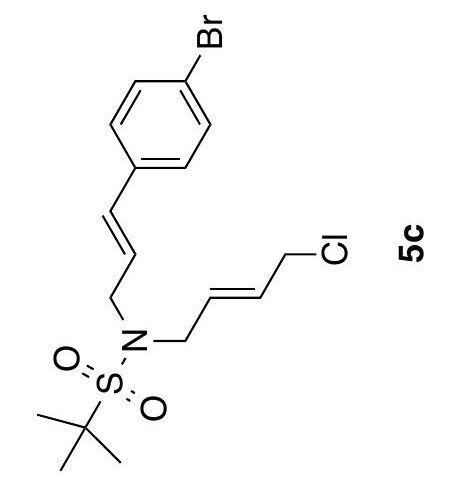




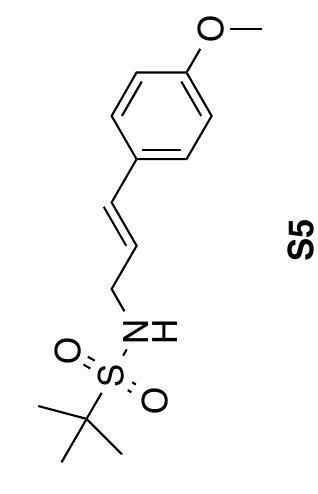






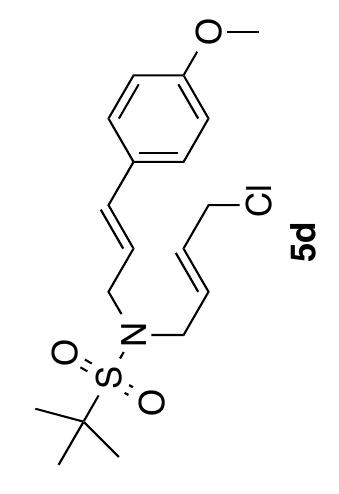




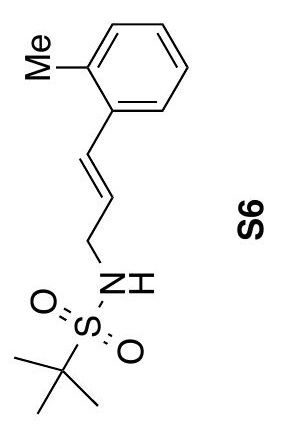




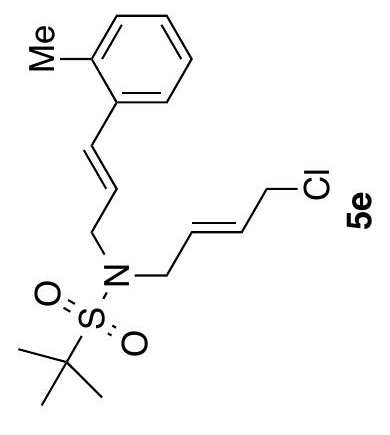




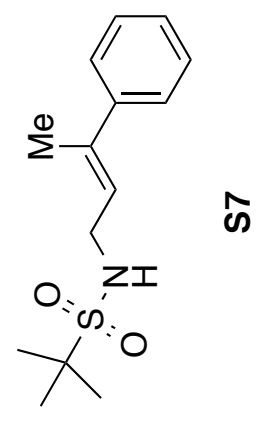




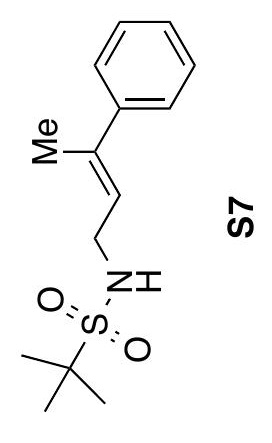





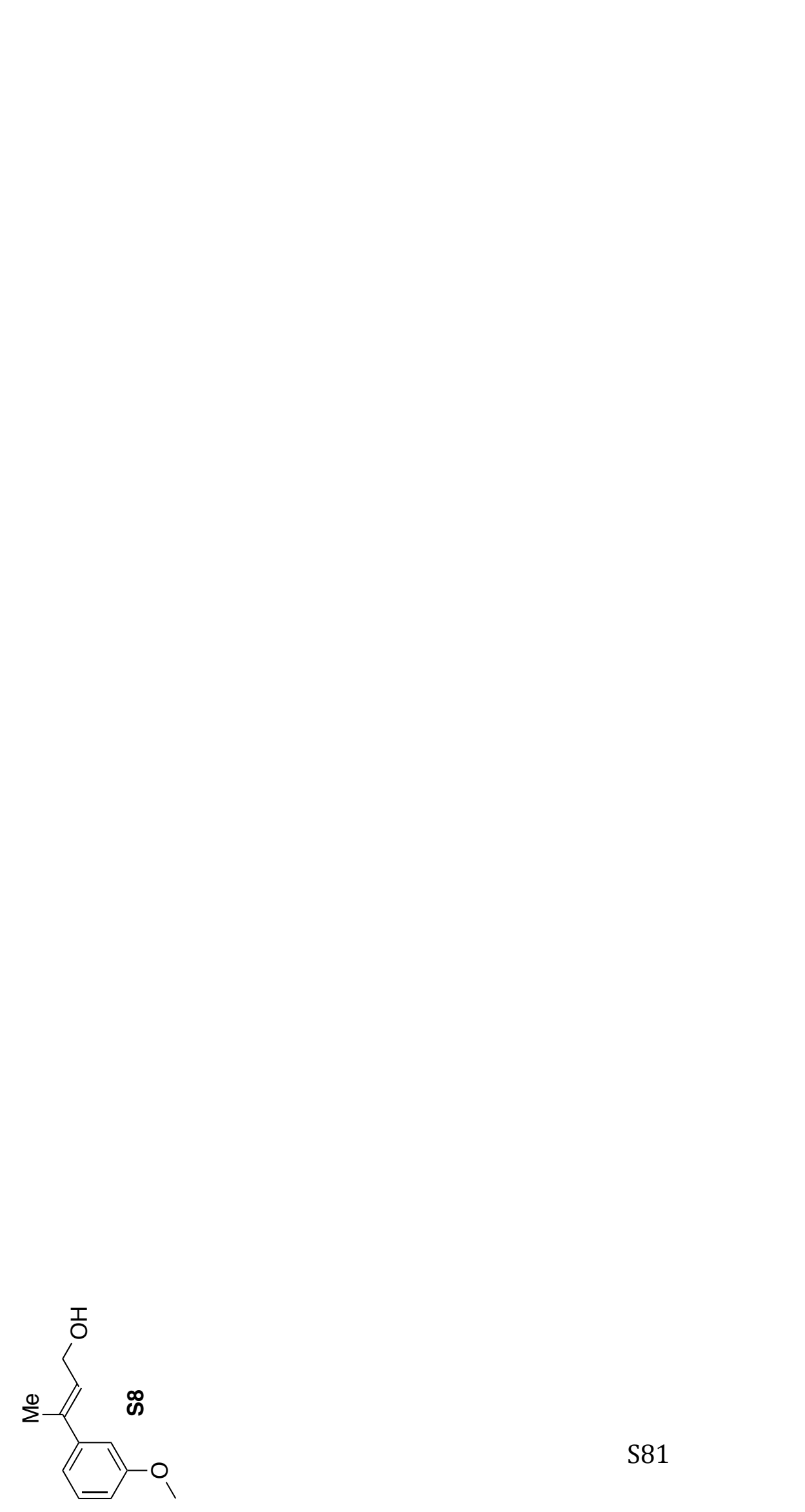


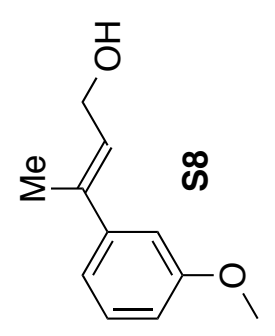





$$
7
$$




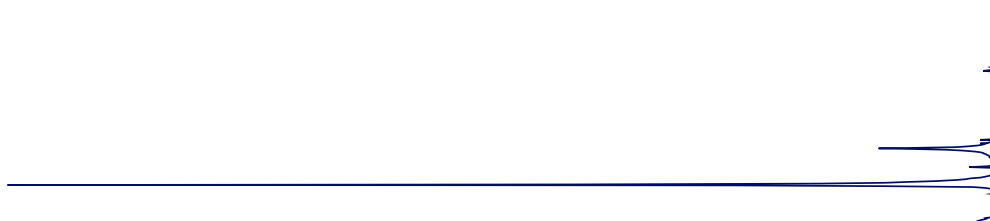




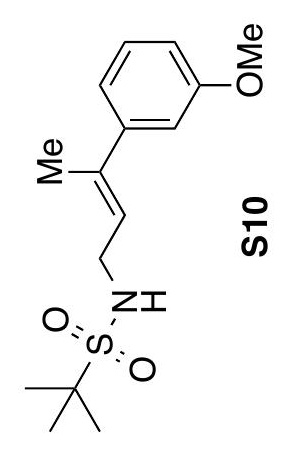




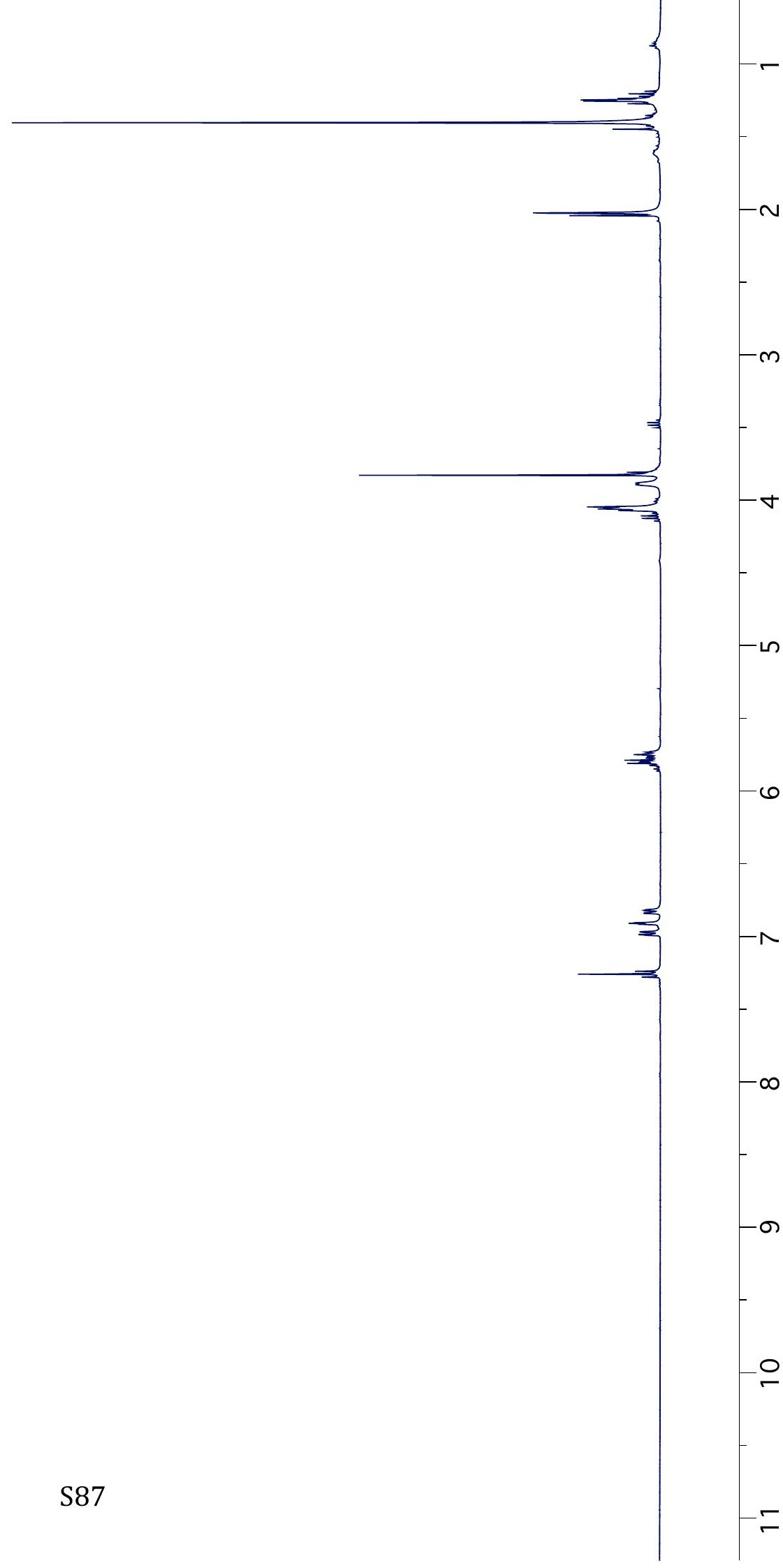




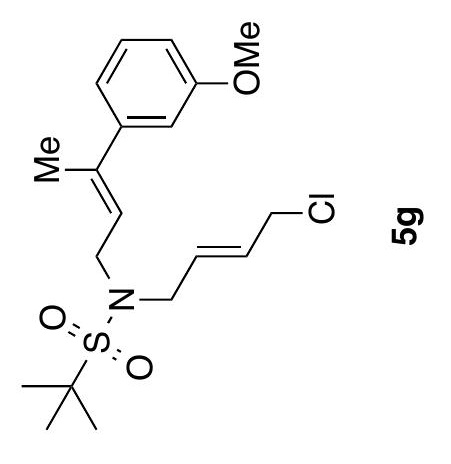





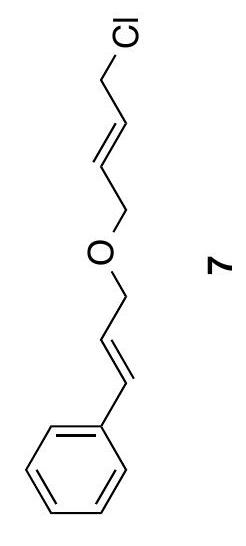




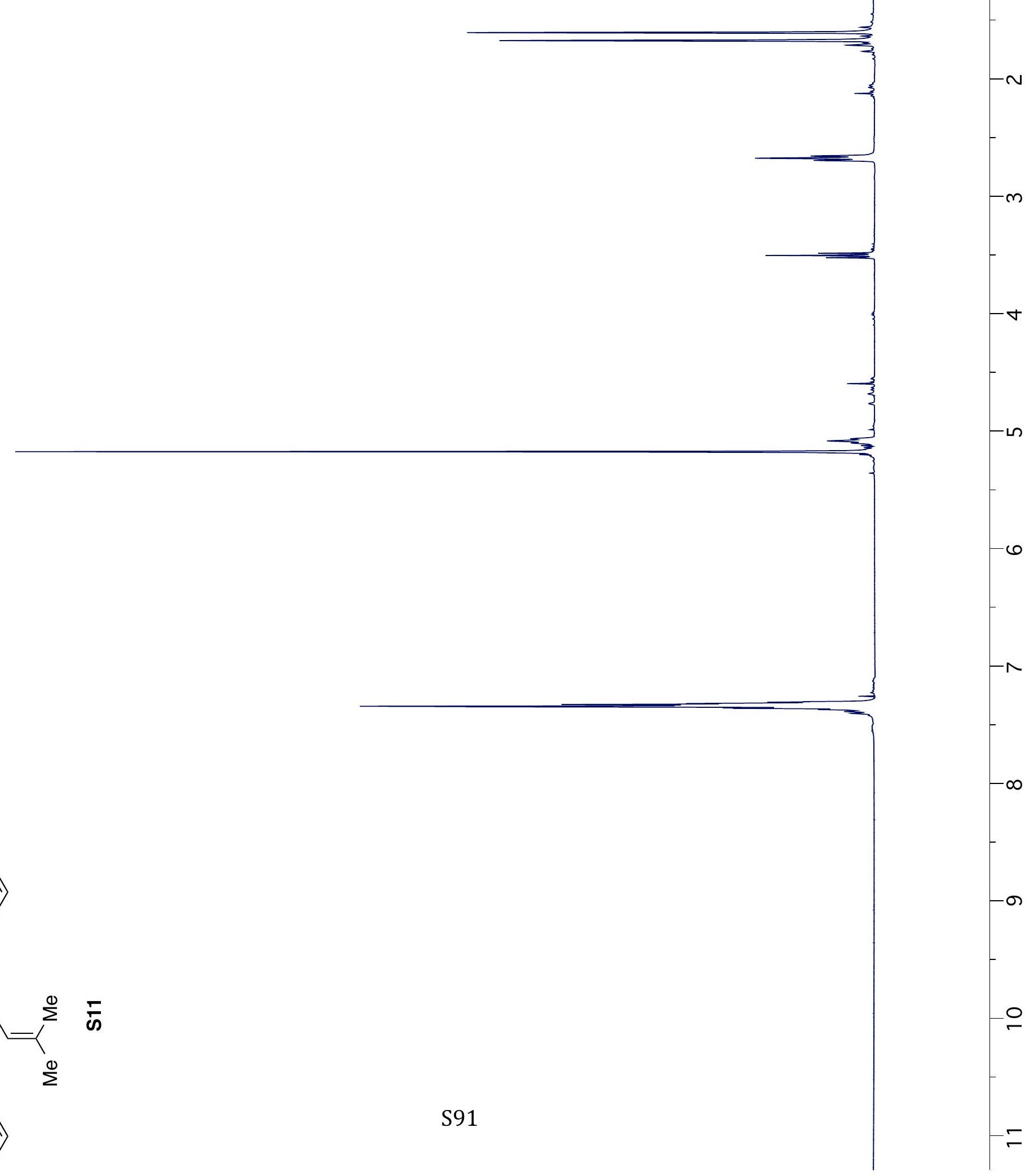




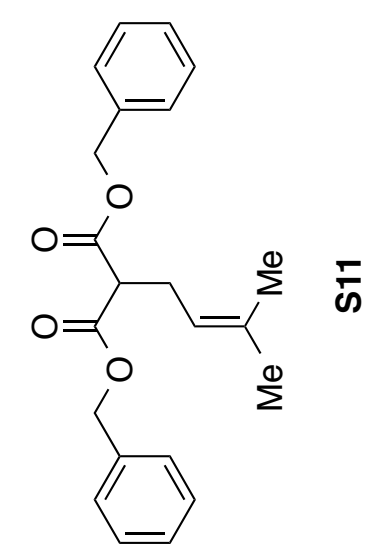







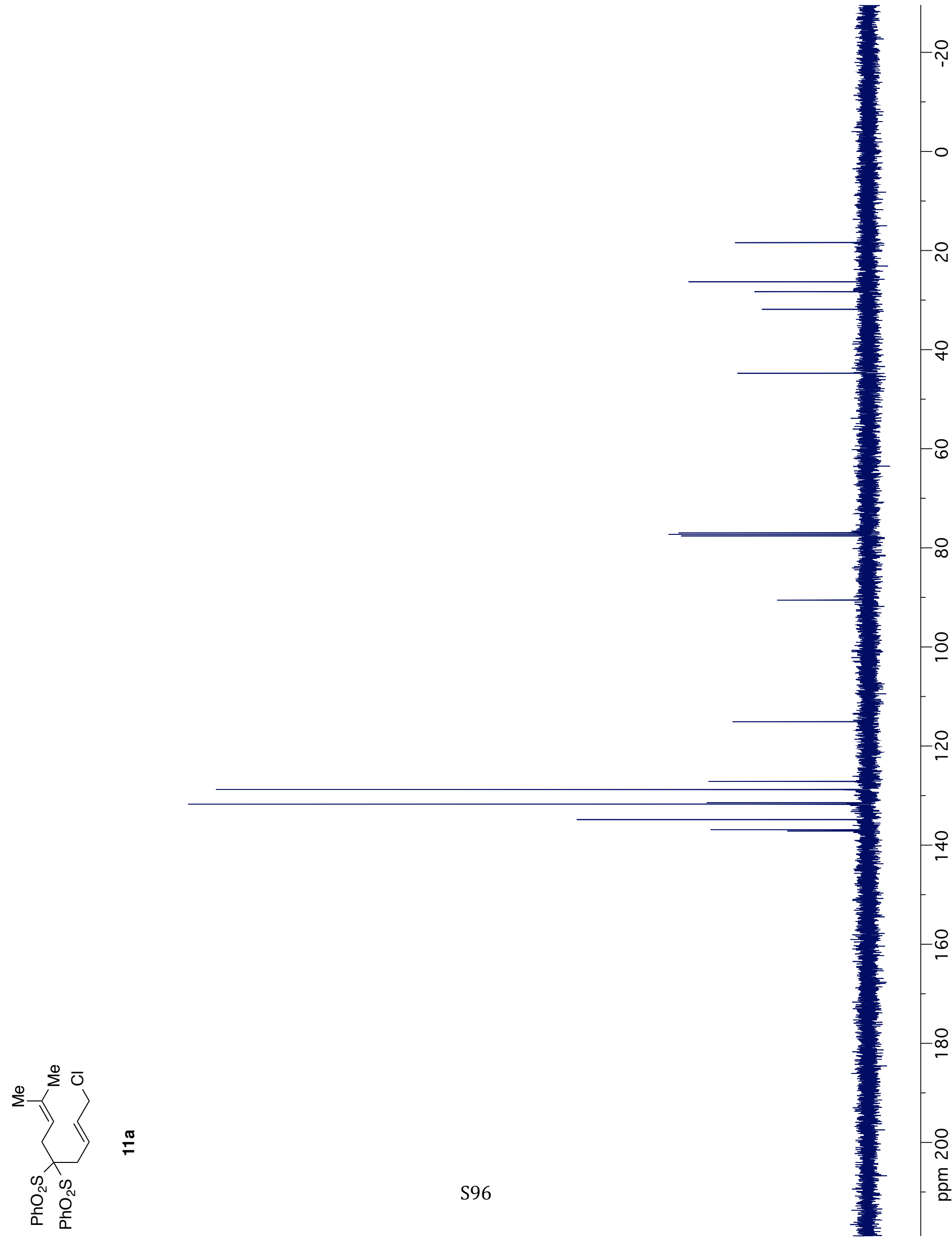





$$
\exists
$$




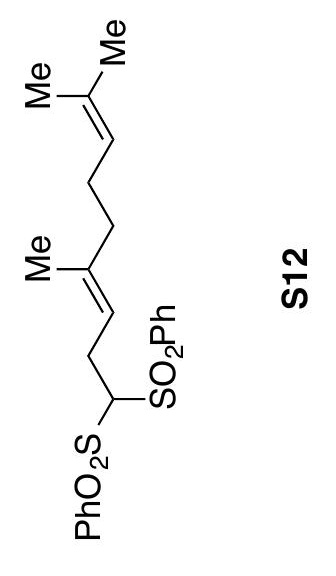




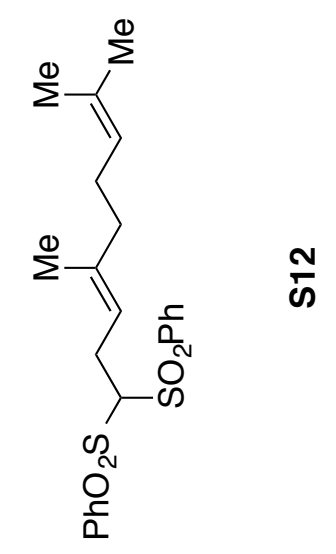




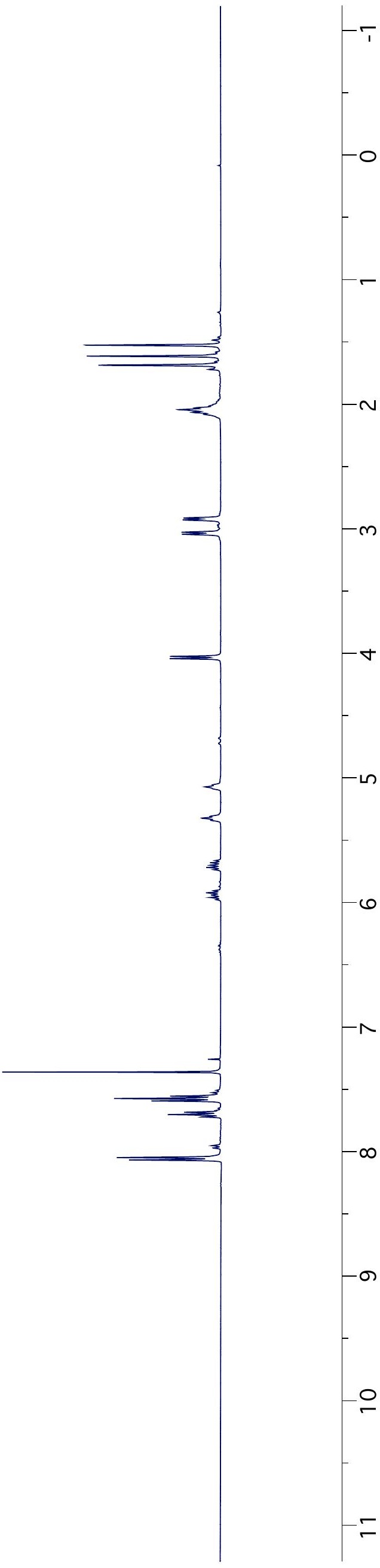




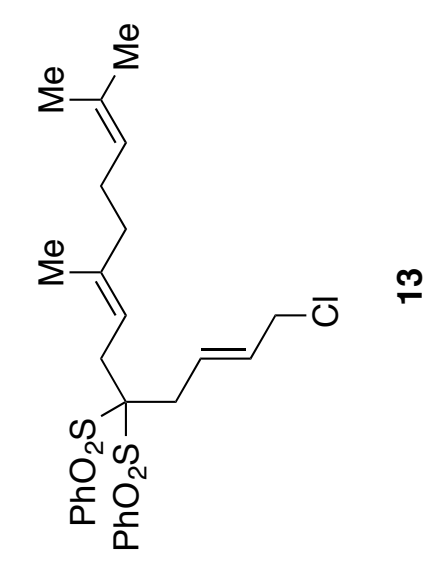




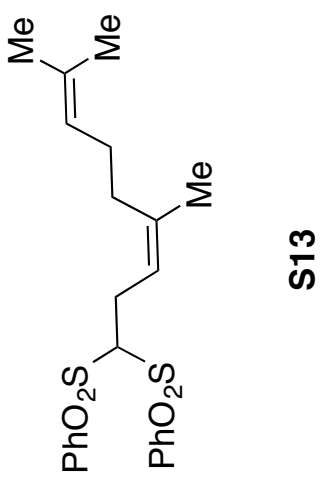




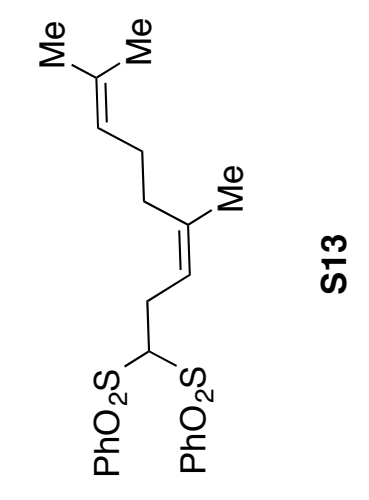




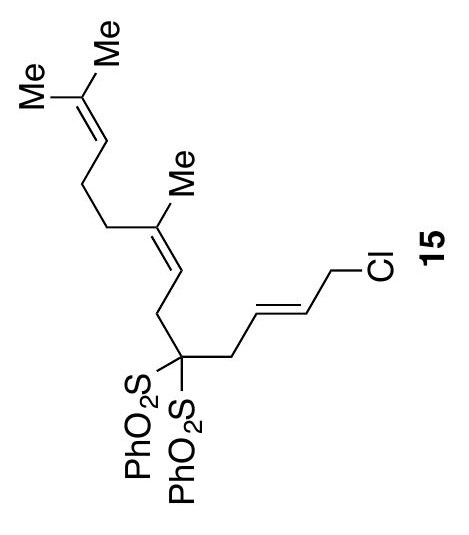





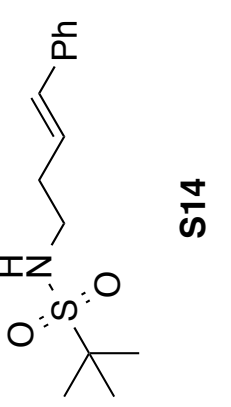




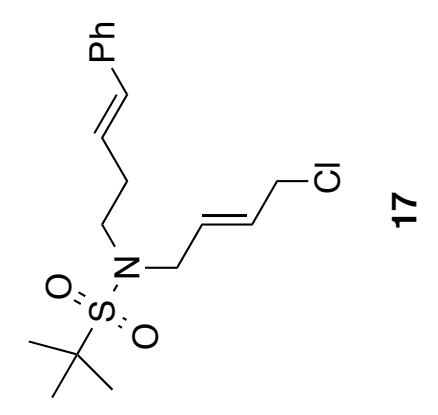




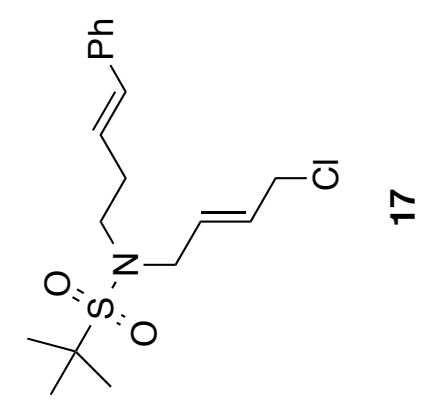





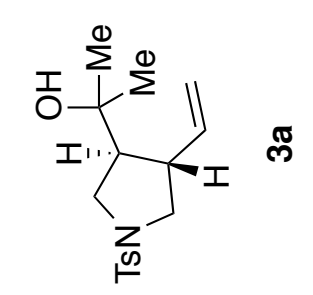




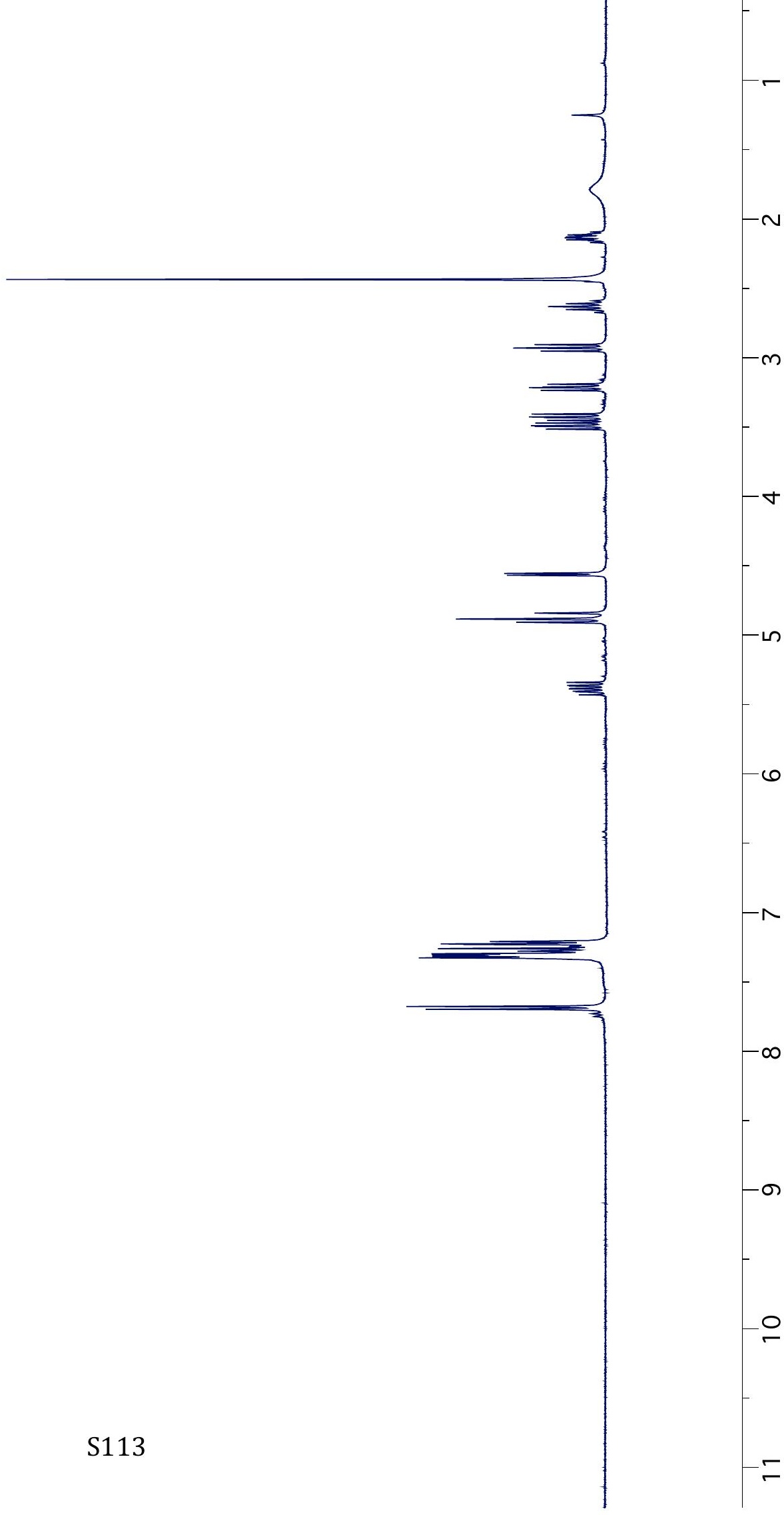





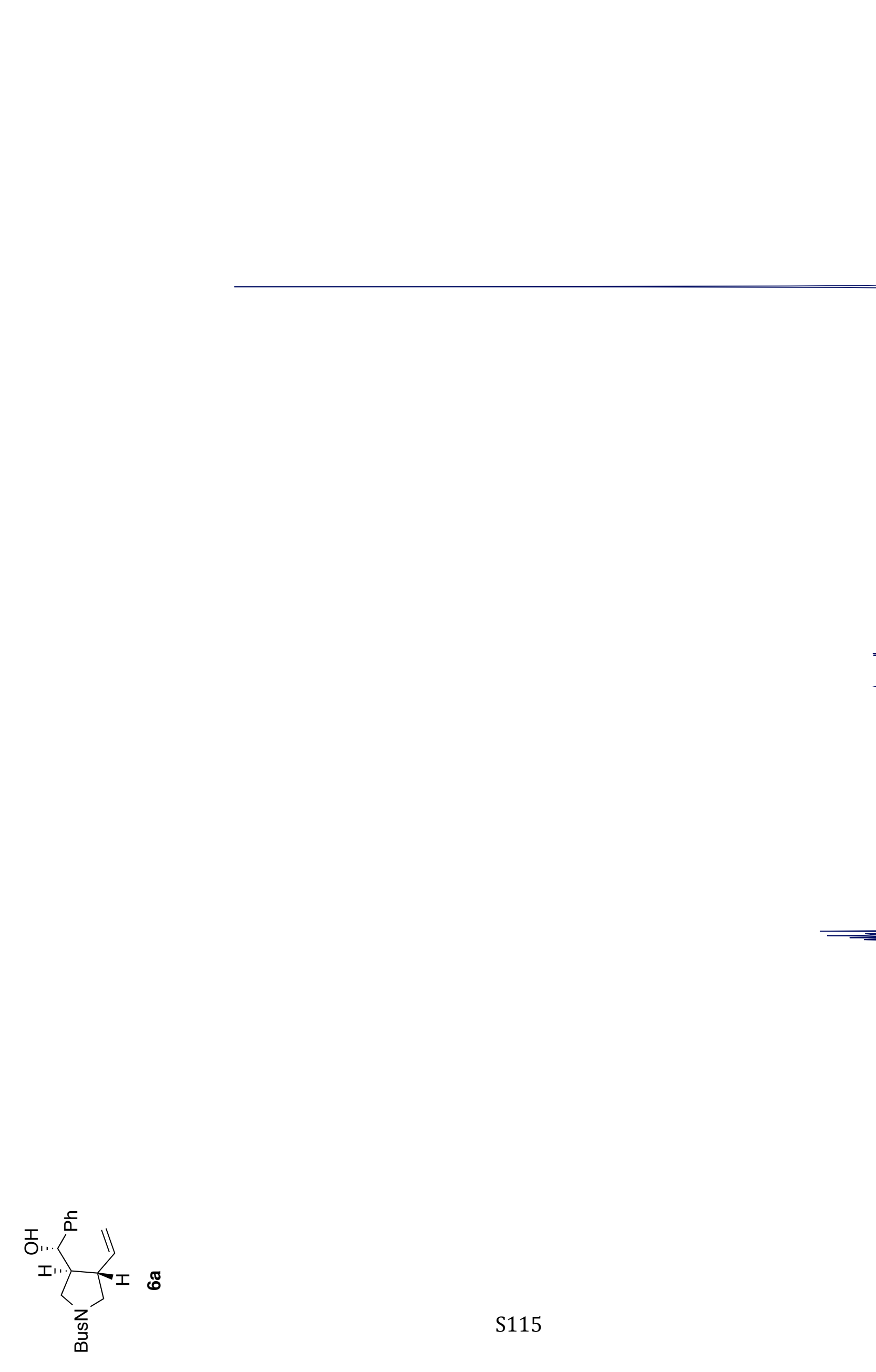




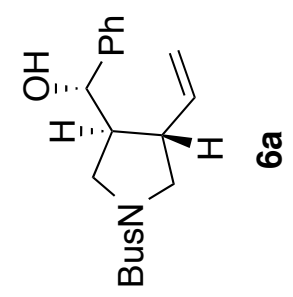




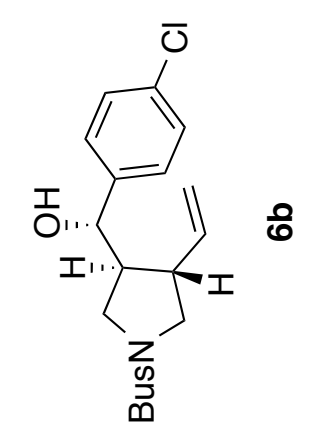




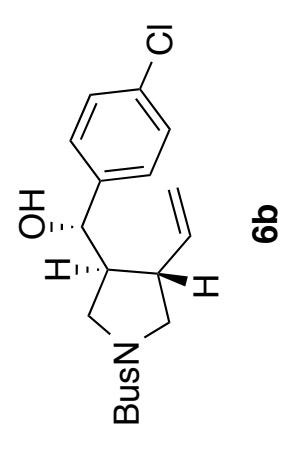




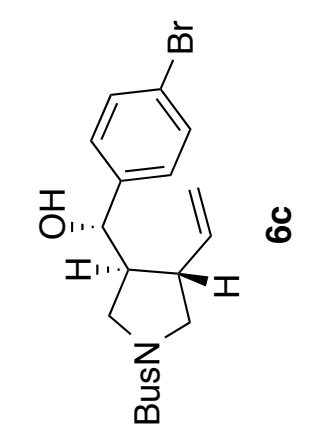




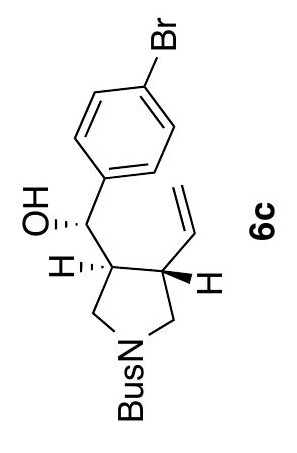




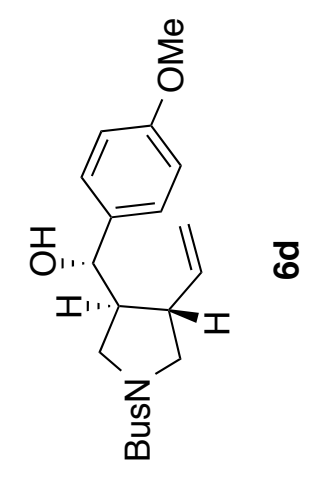




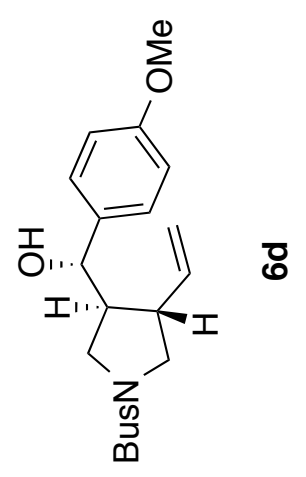





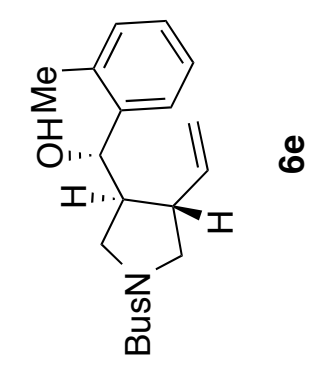




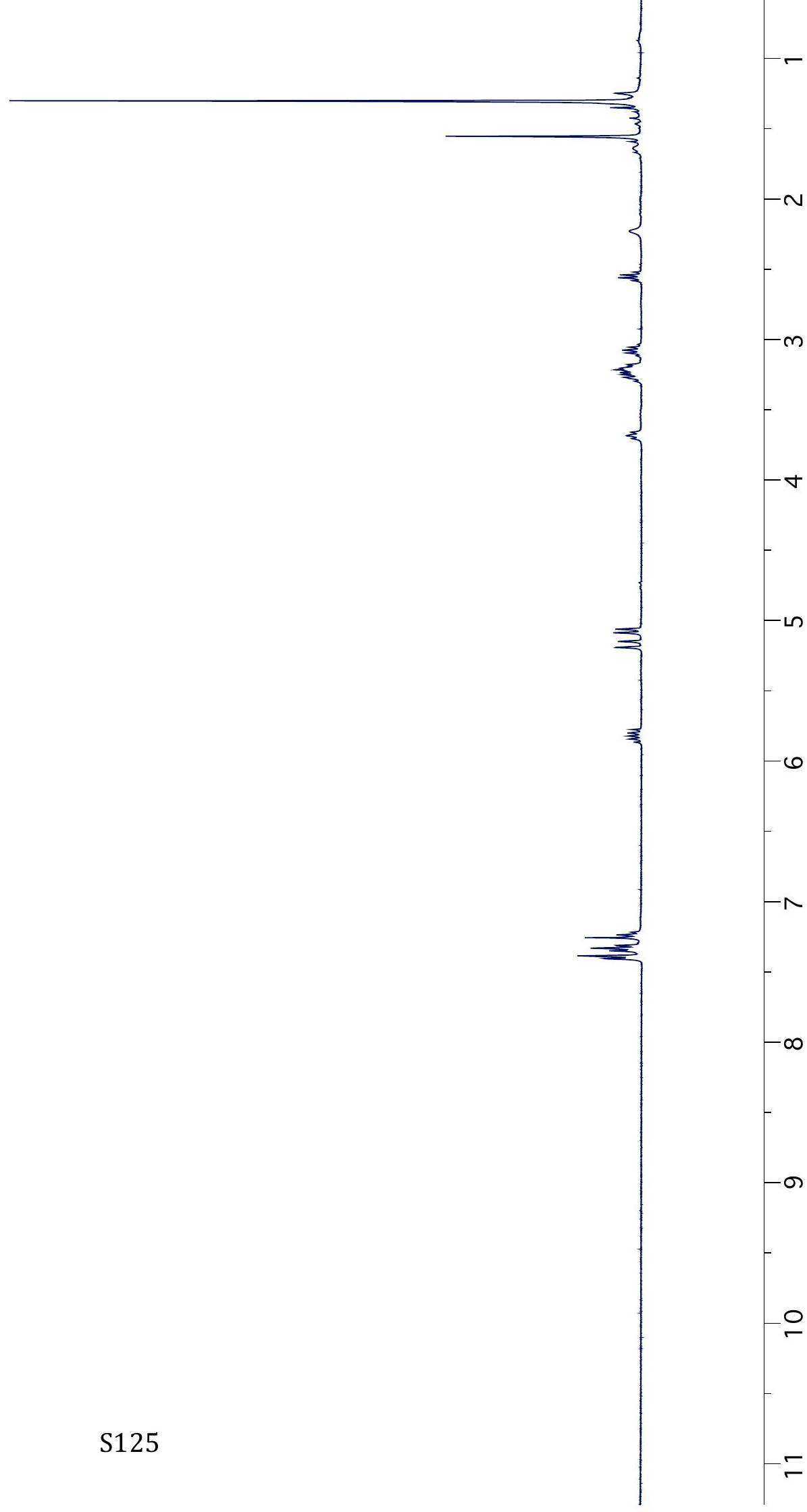




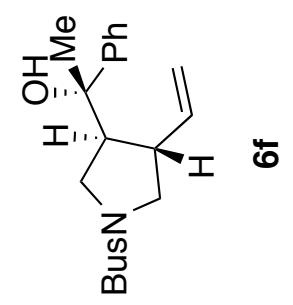








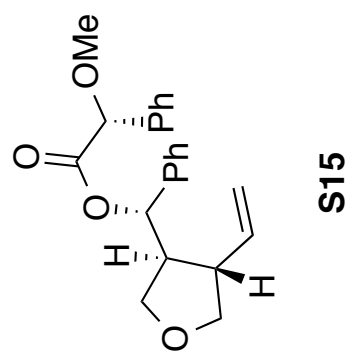




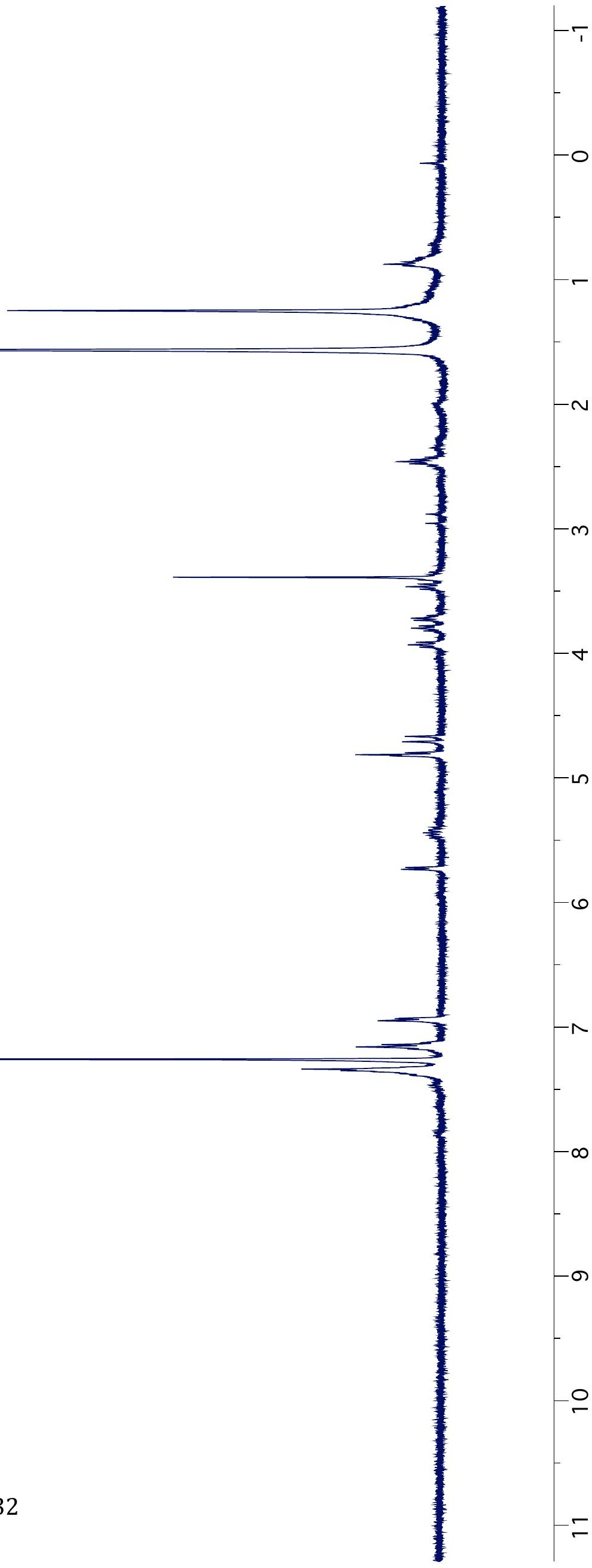




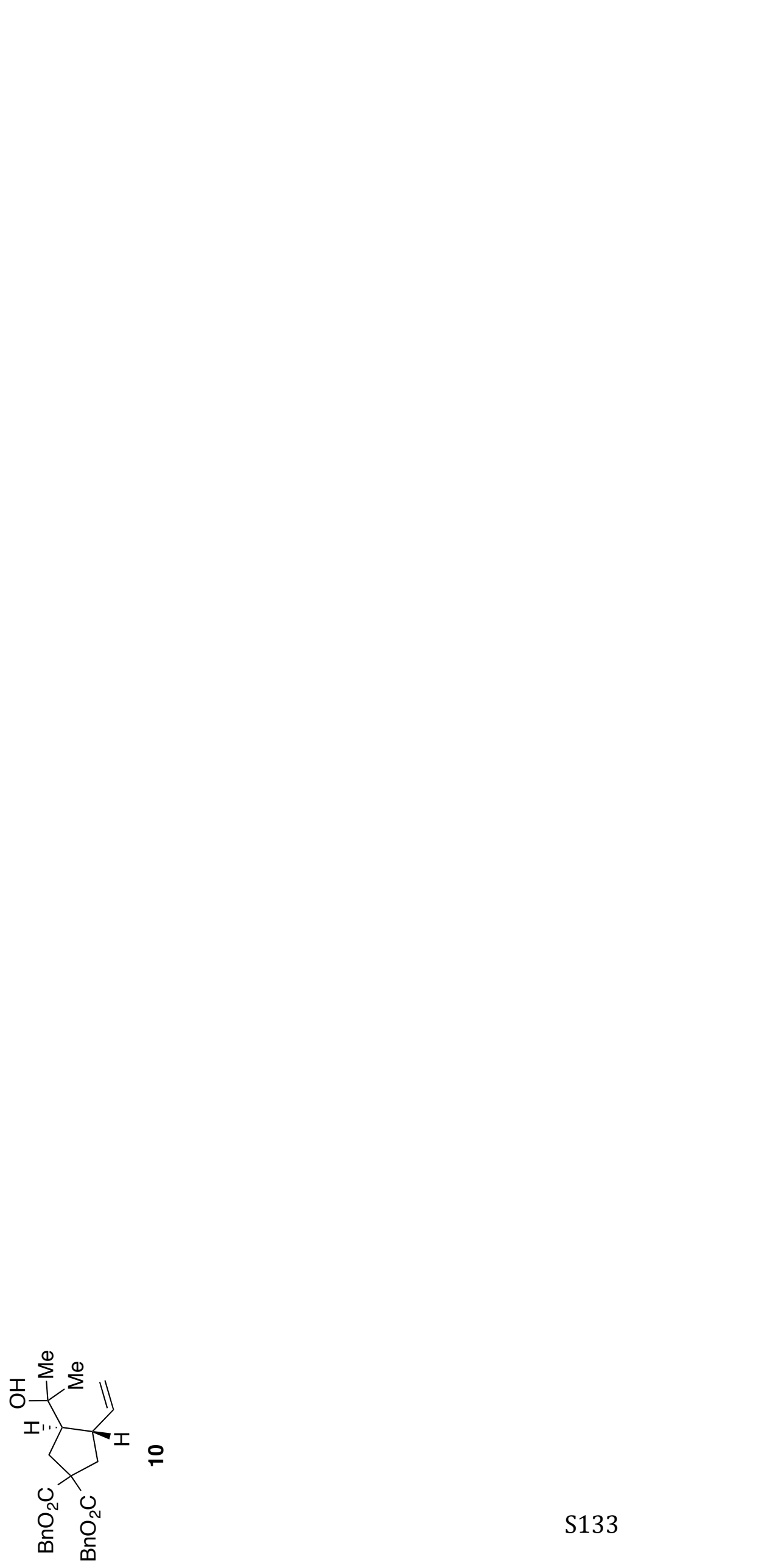




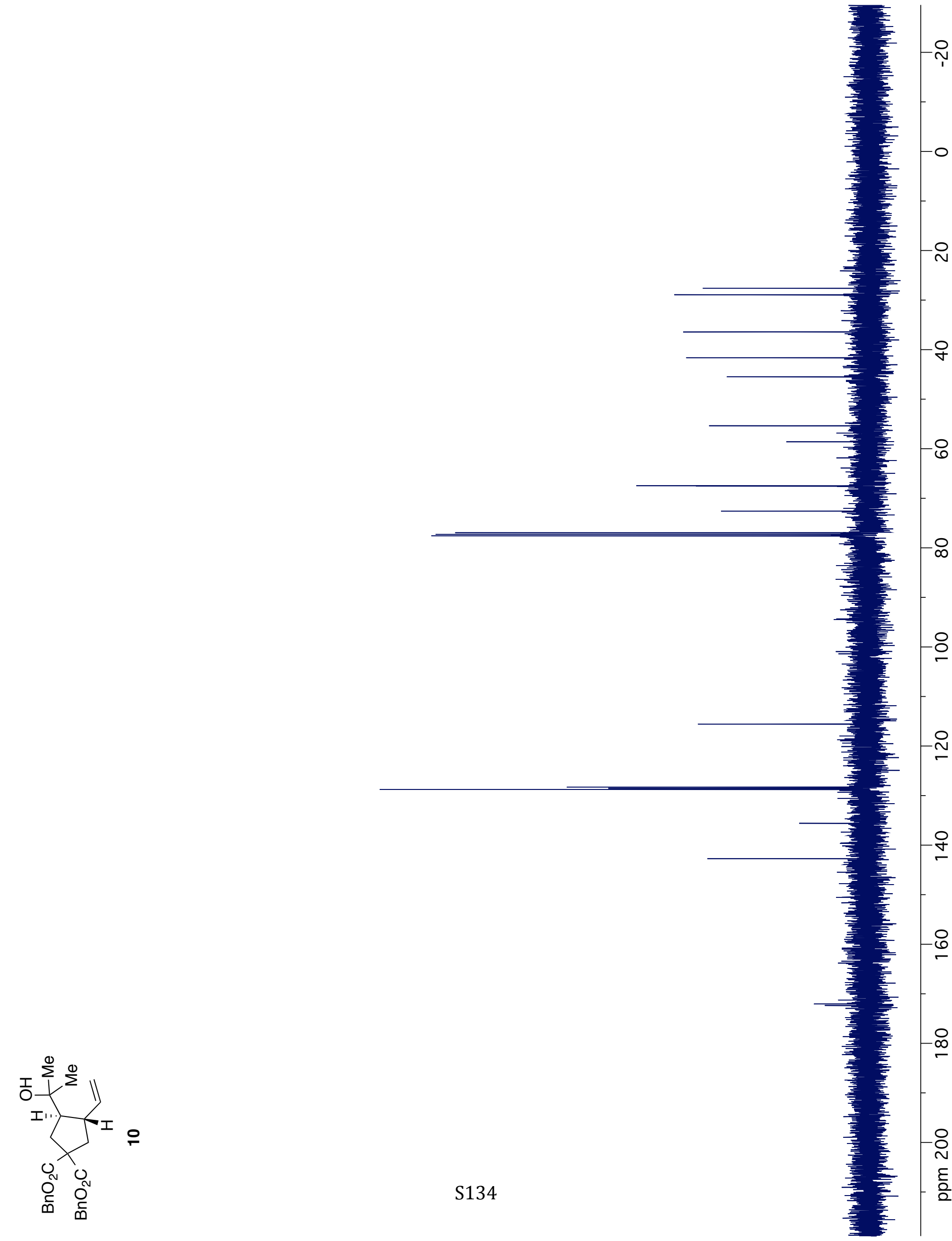





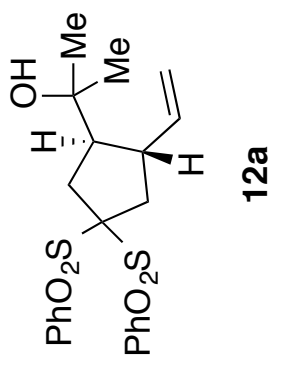





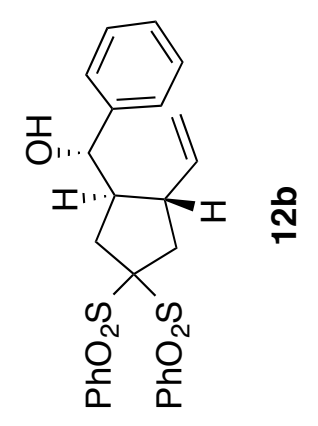





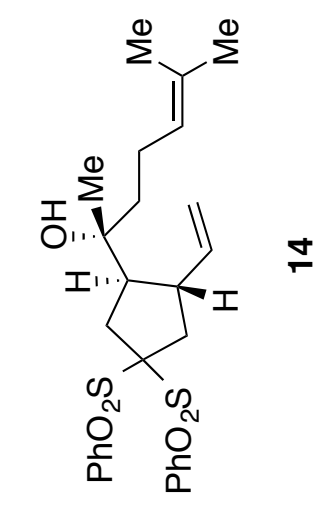





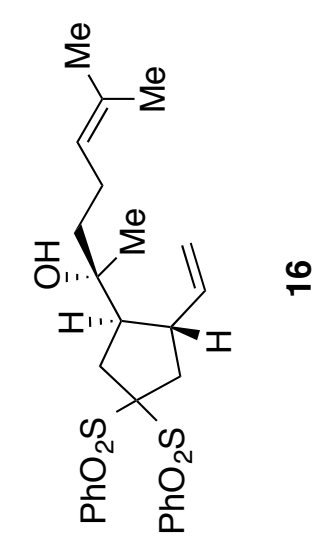




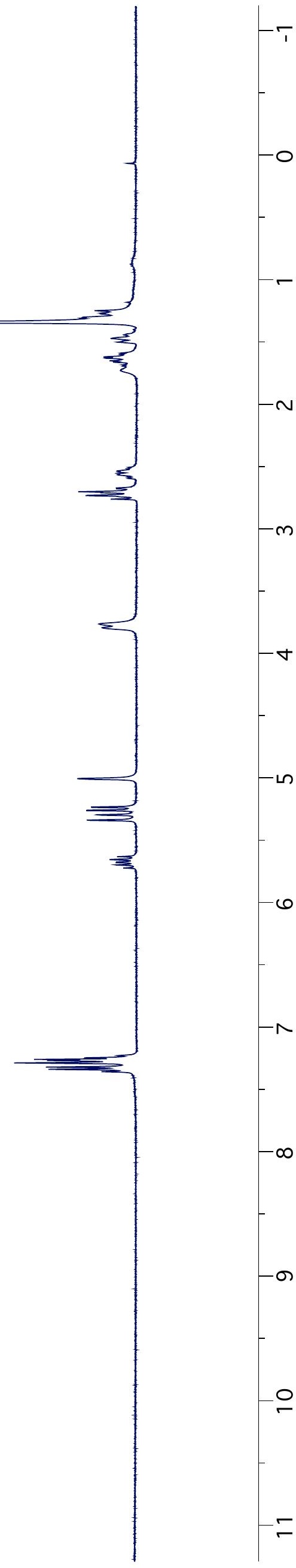




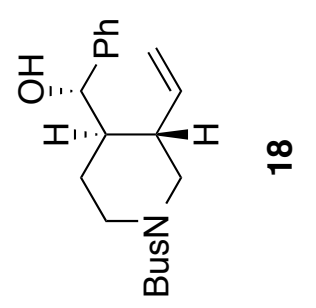




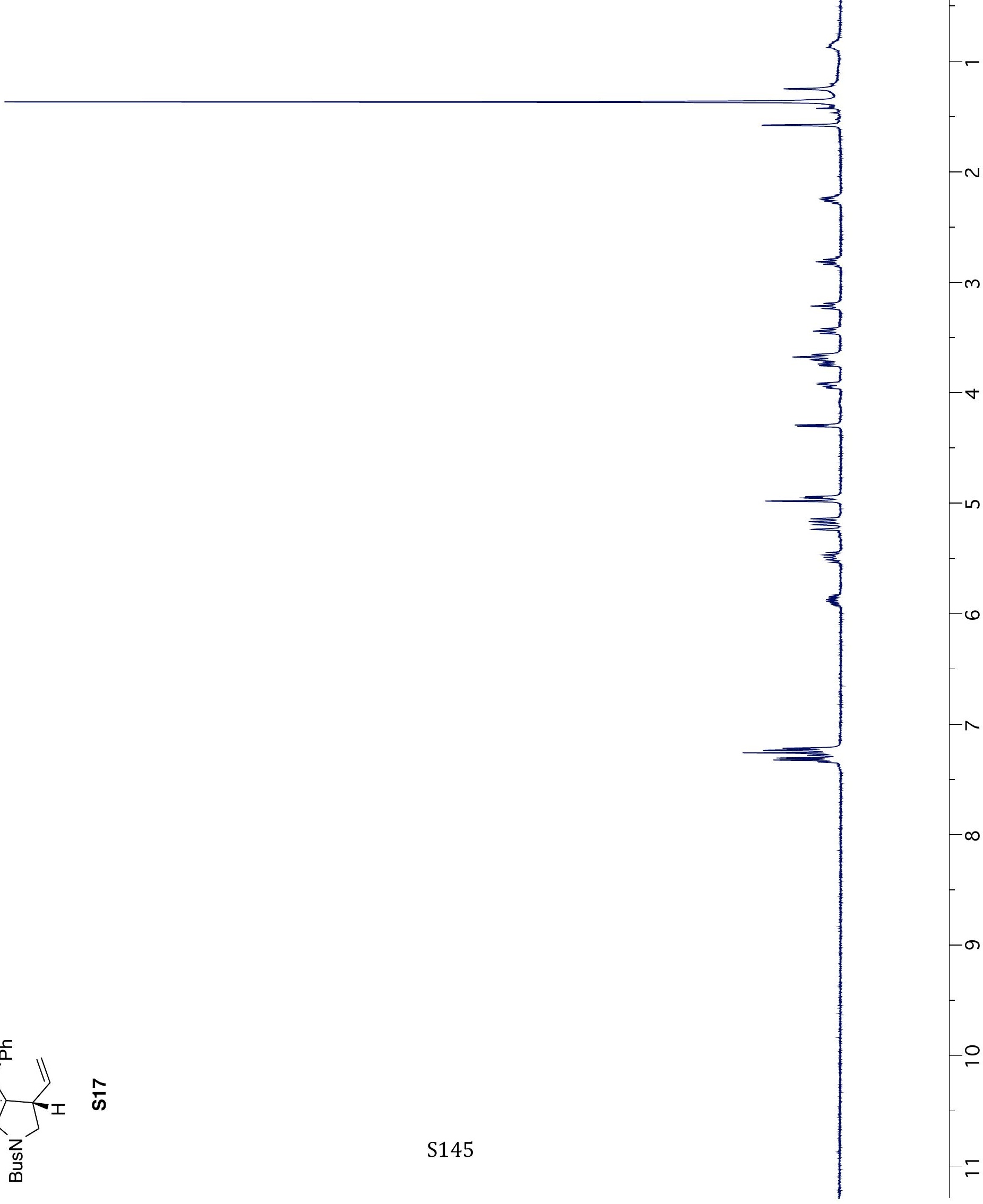




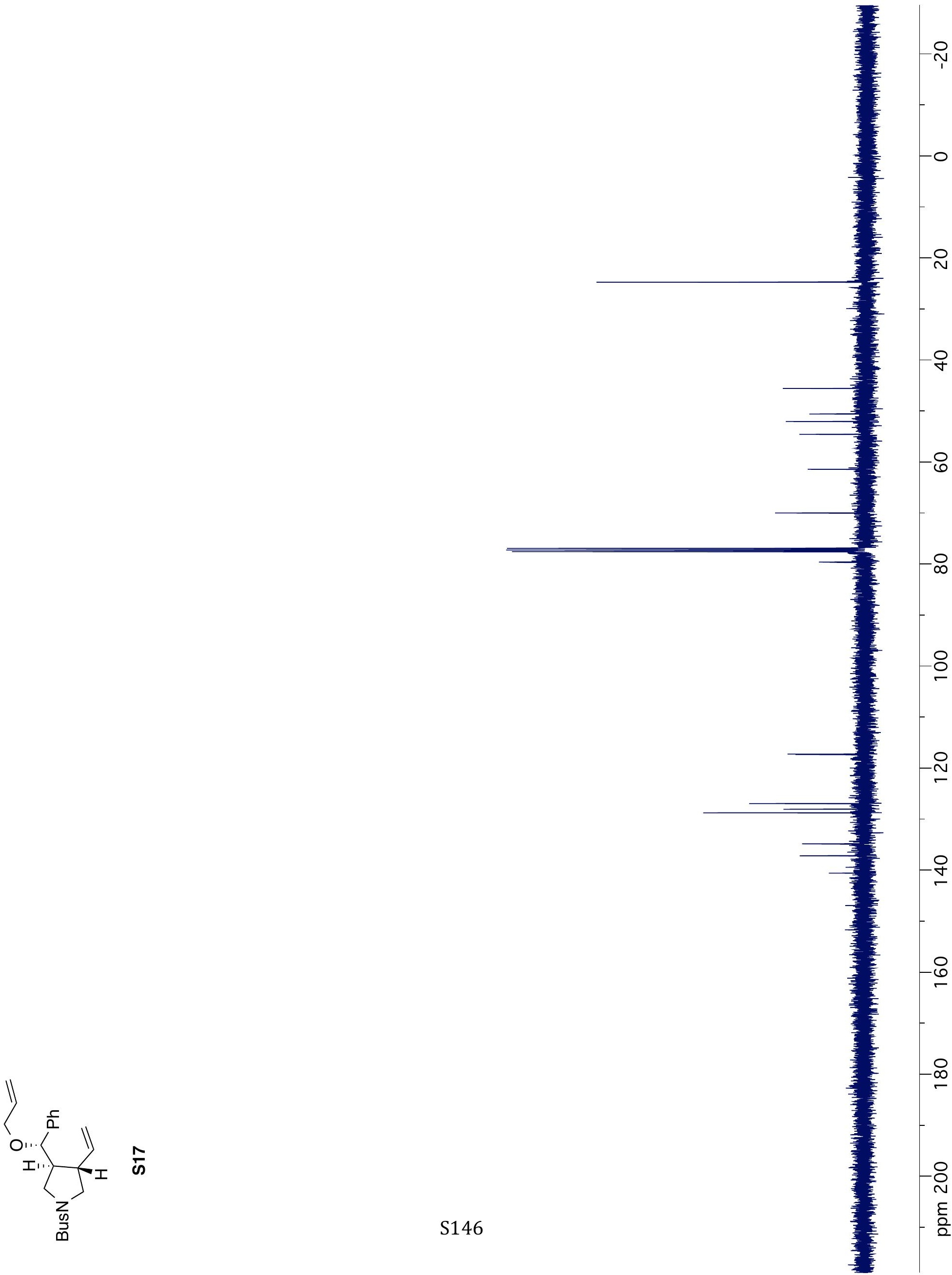






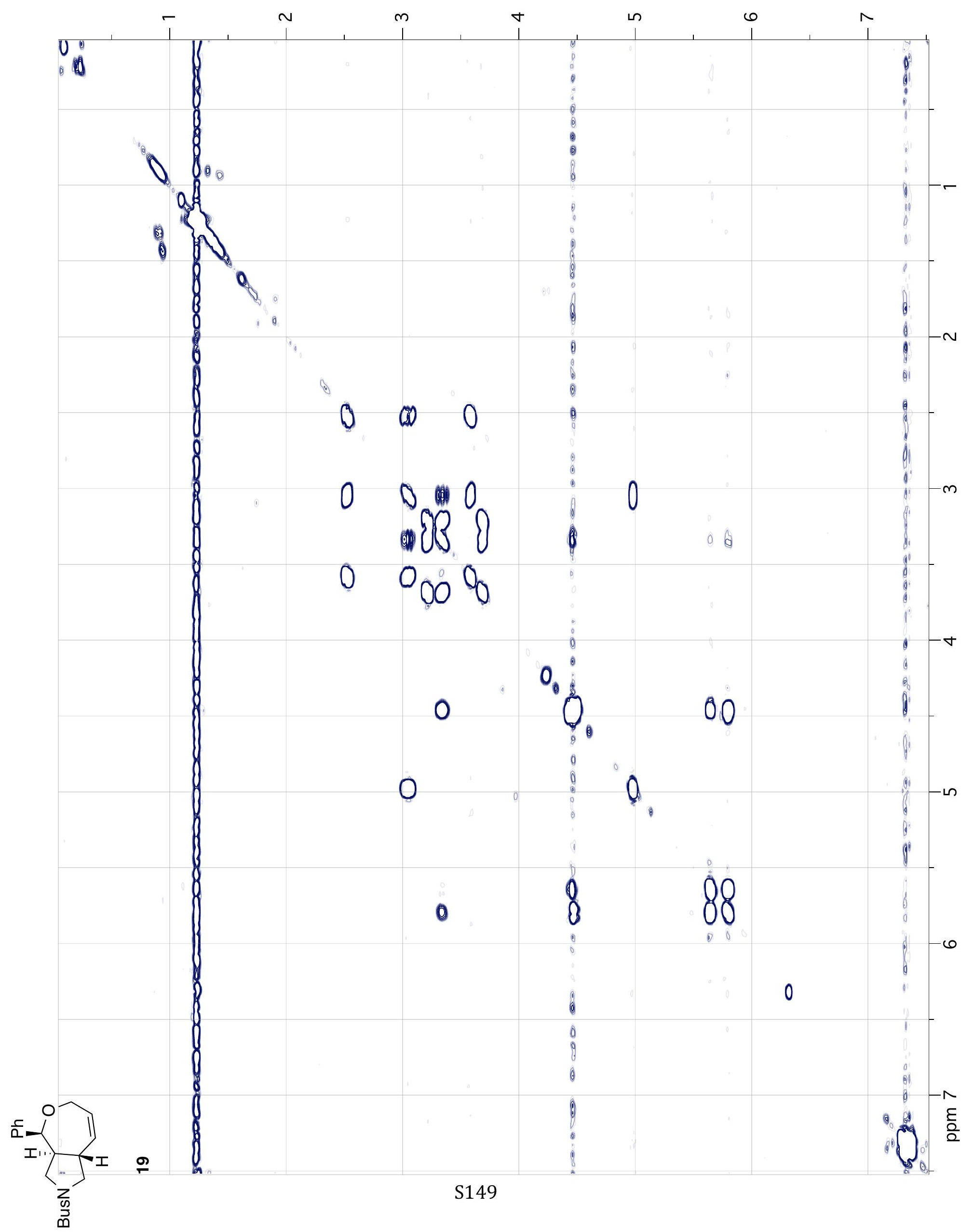




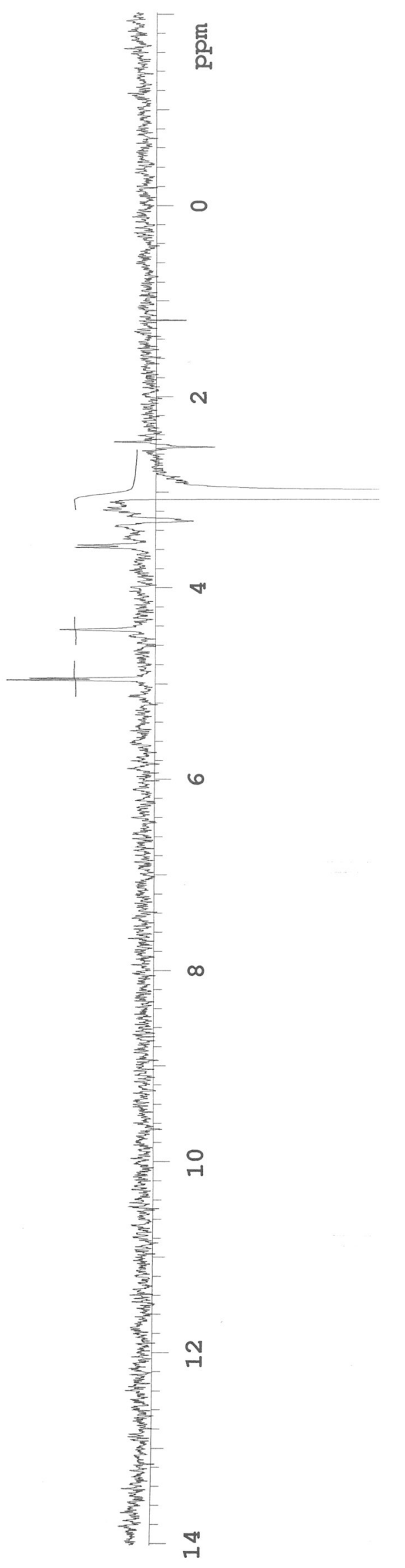



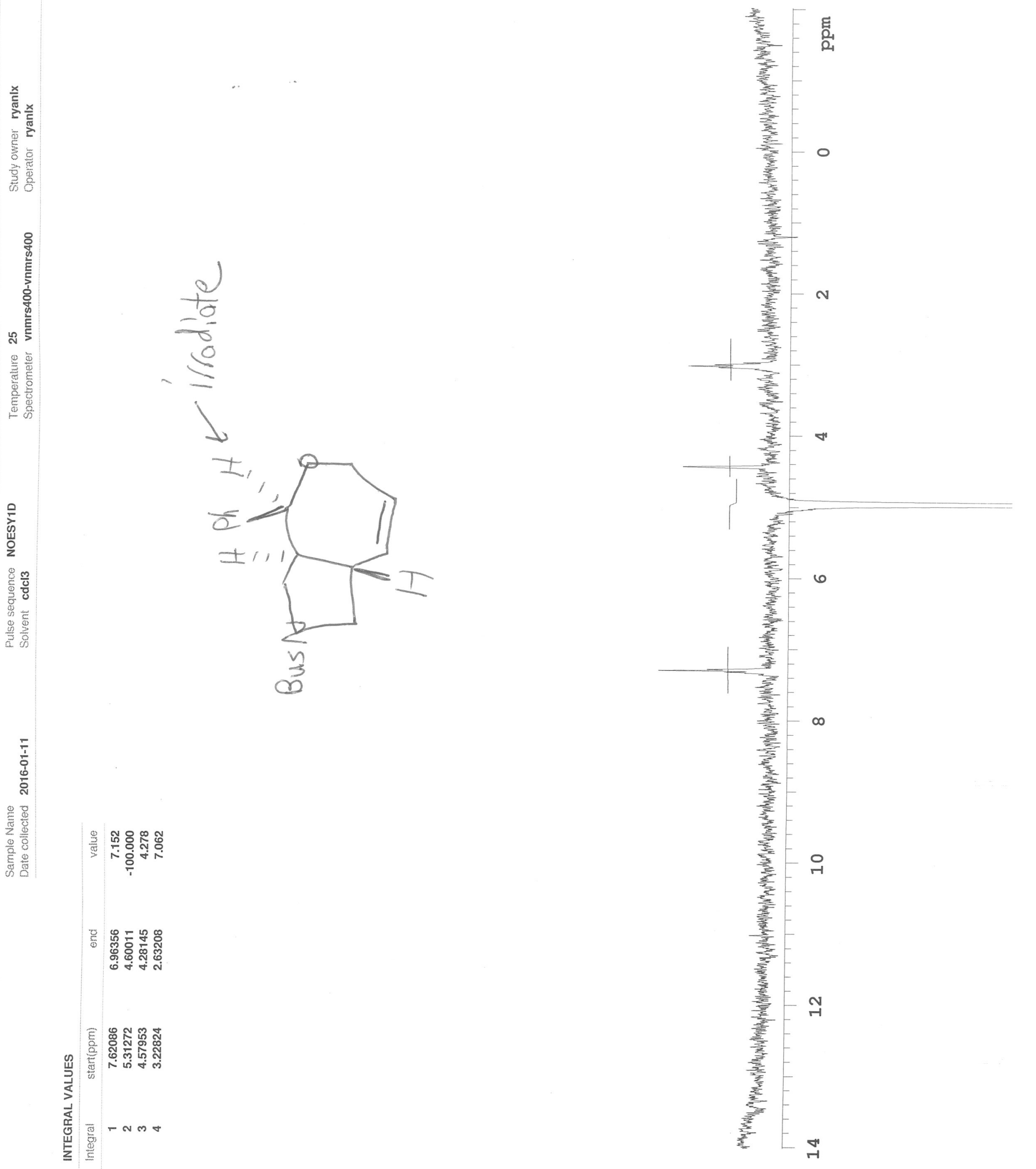

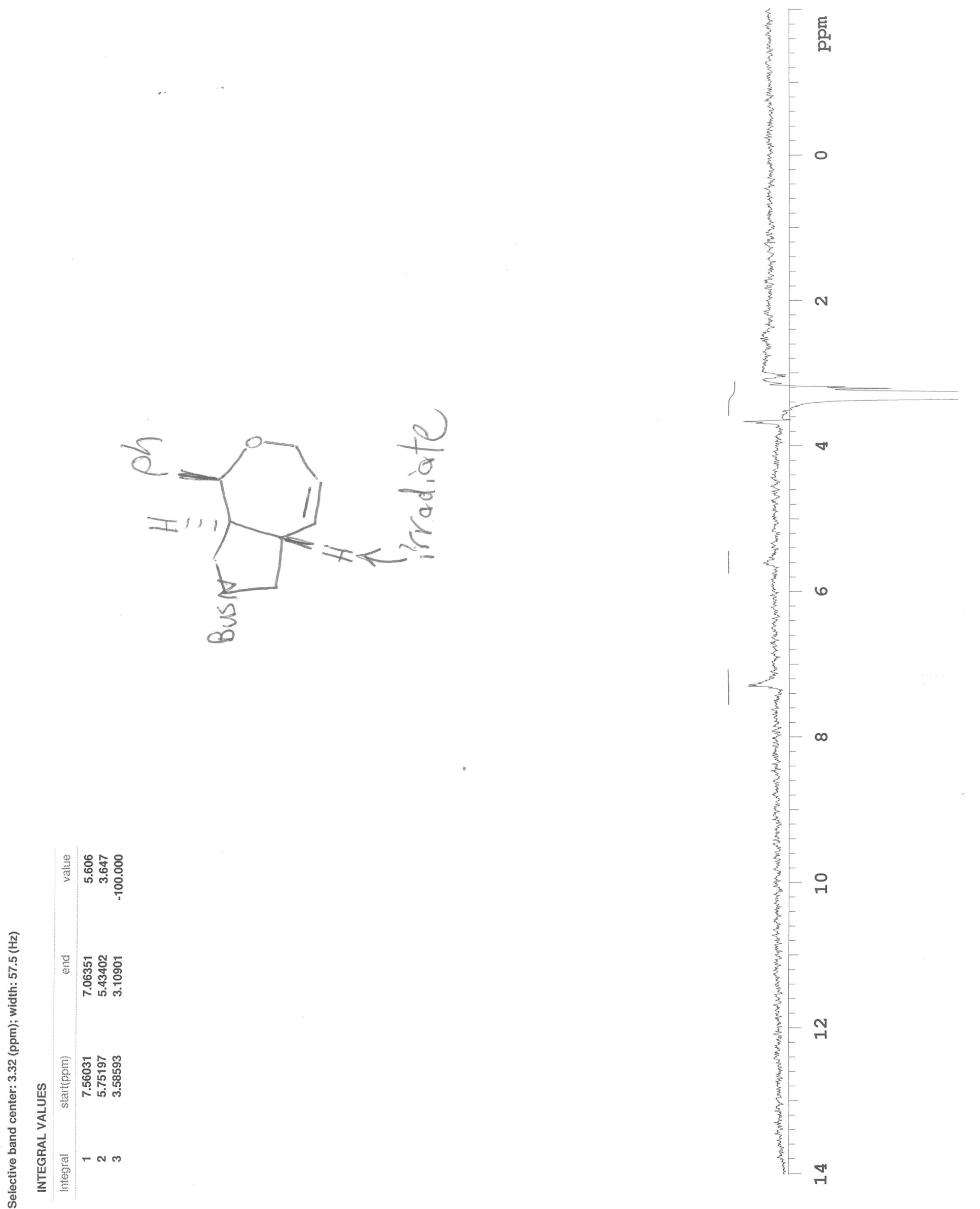


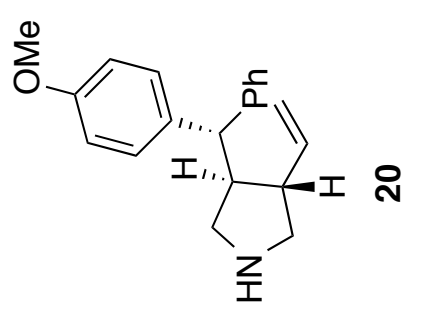




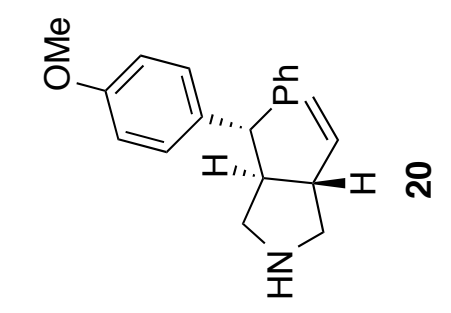




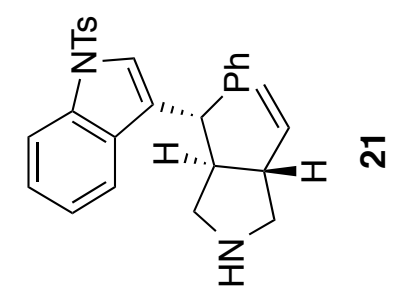




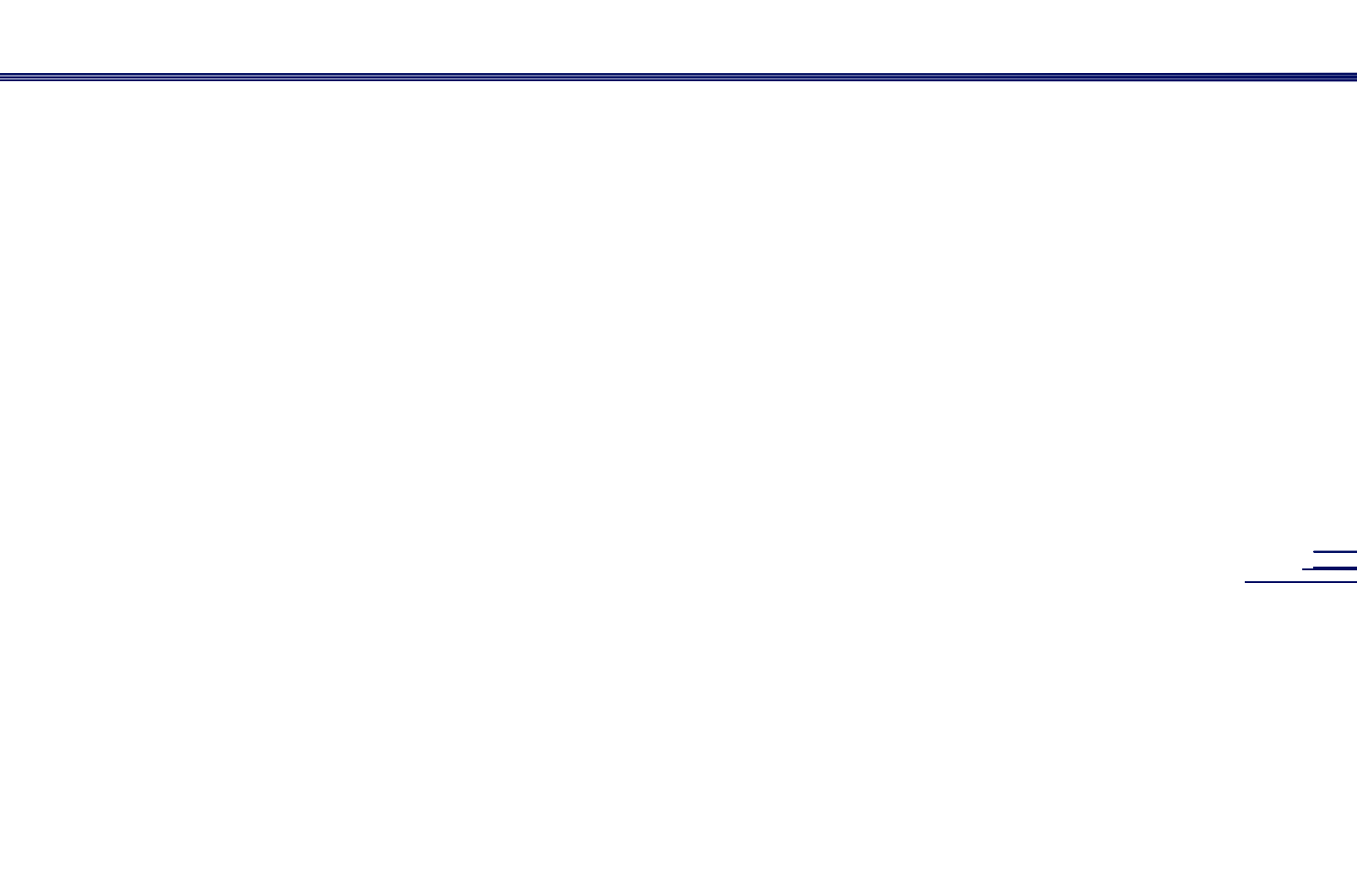


$\underbrace{\infty}_{\text {Z⿱一土 }}$ 



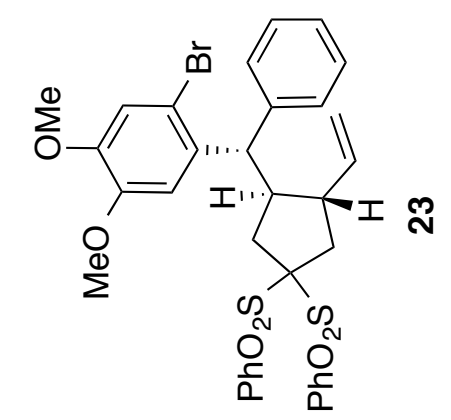




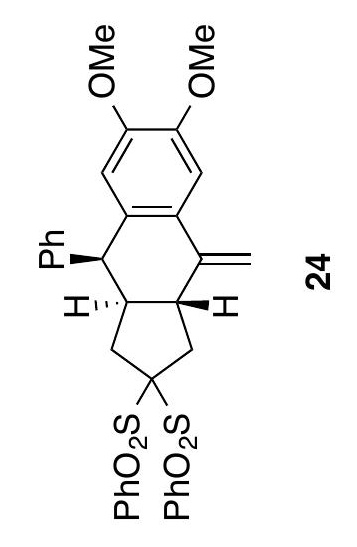




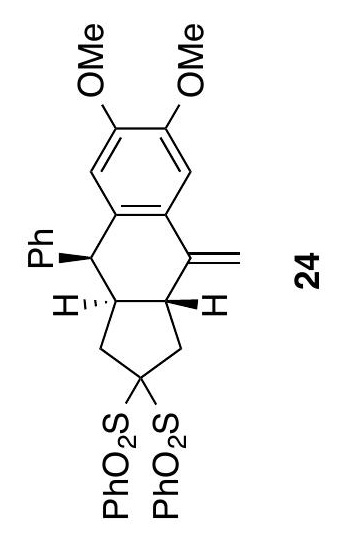

